\title{
PEMBELAJARAN E-LEARNING DI MASA PANDEMI
}

\author{
Balqis Husain, M.Pd.B.I \\ Megawati Basri, M.Pd
}

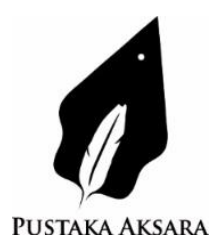




\title{
PEMBELAJARAN E-LEARNING DI MASA PANDEMI
}

\author{
Penulis $\quad$ : Balqis Husain, M.Pd.B.I \\ Megawati Basri, M.Pd \\ Desain Sampul : Rizal Fahmi AS \\ Tata Letak : Adam Akbar
}

ISBN : 978-623-95776-8-1

Diterbitkan oleh : PUSTAKA AKSARA

\section{Redaksi:}

Jl. Karangrejo Sawah IX nomor 17, Surabaya

Telp. 0858-0746-8047

Laman : www.pustakaaksara.co.id

Surel : info@pustakaaksara.co.id

Cetakan Pertama : 2021

All right reserved

Hak Cipta dilindungi undang-undang

Dilarang memperbanyak atau memindahkan sebagian atau seluruh isi buku ini dalam bentuk apapun dan dengan cara apapun, termasuk memfotokopi, merekam, atau dengan teknik perekaman lainnya tanpa seizin tertulis dari penerbit. 


\section{KATA PENGANTAR}

Alhamdulilah, ucapan puji dan syukur kami panjatkan kehadirat Tuhan Yang Maha Esa (Allah SWT), atas berkat rahmat dan inayah-nya, sehingga penulisan buku ini dapat terselesaikan. Kehadiran buku ini, termotivasi dengan kondisi bangsa kita Indonesia, yang dilanda oleh Virus COVID-19, mengakibatkan seluruh proses belajar mengajar hanya dapat dilaksanakan secara daring; sistem ini mengharuskan semua pihak (guru, siswa bahkan orang tua) diharuskan untuk dapat mengoperasikan internet dalam proses belajar mengajar. Penggunaan internet sebagai media pembelajaran bukanlah hal baru dalam dunia pendidikan, dikarenakan sudah sering digunakan oleh tenaga pendidik, peserta didik maupun stakeholder yang terkait di dalamnya. Namun perubahan kondisi belajar ini sangat berpengaruh terhadap proses maupun hasil dari pembelajaran tersebut, dikarenakan tenaga pendidik maupun peserta didik dituntut untuk mengikuti proses pembelajaran dengan menggunakan media elektronik sebagai media pembelajaran.

Adanya kehadiran buku ini diharapkan menjadi sebuah pegangan yang konkrit, dan menjadi rujukan atau referensi bacaan bagi tenaga pendidik, maupun peserta didik dan komunitaskomunitas bacaan lainnya, khususnya E-Learning. Elektronik Learning atau E-Learning adalah salah satu model pembelajaran yang didukung dan difasilitasi oleh pemanfaatan teknologi informasi (TI). E-Learning sendiri telah diaplikasikan oleh dosen di Universitas Pasifik Morotai. Pemanfaaatan media pembelajaran ini tentunya berbeda penerapanya pada wilayah-wilayah lainnya yang ada di Indonesia, khusunya Maluku Utara. Sebab letak geografis wilayah juga sangat mempengaruhi aksebilitas dan konektivitas dari jaringan tersebut, dimana Pulau Morotai merupakan daerah afirmasi yang memiliki koneksi jaringan internet kurang maksimal serta perangkat hardware yang belum memadai.

Kami berharap semoga kehadiran buku ini menjadi sebuah amal jariyah bagi penulis dan "oase" bagi para pembaca. Harapan 
kami juga, semoga buku ini dapat menjadi petunjuk dalam pembelajaran E-learning. dengan demikian, buku ini dapat menambah pengetahuan serta informasi terkait dengan E-learning khususnya di daerah afirmasi.

Morotai, 18 Januari 2021

Ketua Program Studi

Pendidikan Bahasa Inggris

Universitas Pasifik Morotai

Megawati Basri, M.Pd 


\section{PRAKATA}

Buku ini membahas tentang pemanfaatan e-learning selama wabah pandemi, masalah yang muncul pada saat penerapan pembelajaran berbasis teknologi di masa pandemic, manfaat penerapan e-learning bagi institusi pendidikan, orang tua, guru, dan siswa, persepsi orang guru terhadap penerapan e-learning serta gagasan-gagasan yang dikemukakan oleh guru guna mendukung dan mengatasi permasalahan yang muncul pada saat penerapan e-learning di masa COVID-19.

Berbagai temuan penelitian baik dari bidang ilmu pendidikan maupun bidang ilmu lain menjadi rujukan oleh buku ini. Selain itu, buku ini mengulas beberapa hasil penelitian yang diperoleh berdasarkan studi kasus di Maluku utara terkait penerapan e-learning di masa pandemi sampai dengan kenormalan baru (new normal). Studi kasus penerapan e-learning di masa pandemic mengangkat permasalahan yang serjadi di semua tingkat pendidikan yakni sekolah dasar sekolah menengah pertama, sekolah menengah atas maupun di tingkat perguruan tinggi. Adapun permasalahan yang di kaji baik dari sudut pandang pendidik, orang tua, siswa dan tidak terkecuali institusi pendidikan.

Saya menyampaikan terima kasih kepada civitas akademika Program Studi Pendidikan Bahasa Inggris yang telah membantu dalam penyusunan buku ini sehingga berhasil diterbitkan pada tahun 2020 ini. Semoga kesempatan ini menjadi momen yang baik bagi civitas akademika Program Studi Pendidikan Bahasa Inggris Universitas Pasifik Morotai (UNIPAS) dalam meningkatkan kualitas dan kuantitas karya akademik mereka. Semoga karyakarya ini menjadi darma bakti kemanusiaan dan amal saleh.

Morotai, 20 Oktober 2020

Penulis 


\section{DAFTAR ISI}

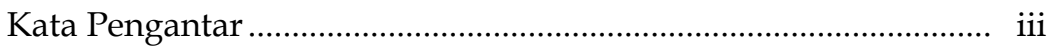

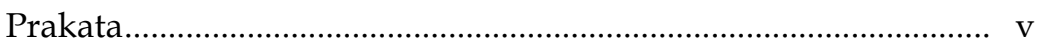

Daftar Isi.................................................................................. vi

BAB I

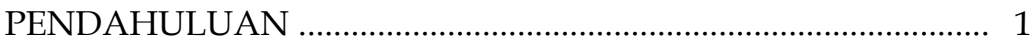

BAB II

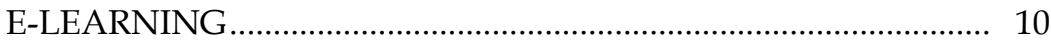

A. Pengertian E-Learning ........................................................ 10

B. Jenis-Jenis E-Learning .......................................................... 13

C. Model Penyelenggaraan E-Learning .................................... 14

D. Batasan E-learning ............................................................... 18

E. Fungsi Pembelajaran Berbasis E-Learning dan Jaringan .... 19

F. Penggunaan Teknologi Informasi dan Komunikasi (TIK) di Dunia Pendidikan ............................................................... 21

G. Institusi Penyelenggara E-Learning..................................... 22

H. Pemanfaatan E-Learning di Dunia Pendidikan.................... 25

I. Paradigma Lama Vs Paradigma Baru E-Learning Pada Pendidikan Tinggi ............................................................. 27

BAB III

MANFAAT E-LEARNING DI MASA PANDEMI .......................... 31

A. Manfaat E-Learning Bagi Perguruan Tinggi........................ 31

B. Manfaat E-Learning di Masa Penyebaran Wabah

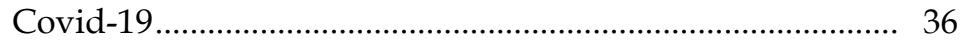

C. Implementasi E-learning dalam Menghadapi Wabah

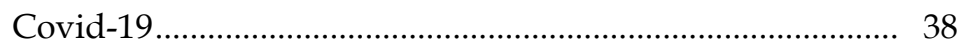

D. Peraturan Model Pembelajaran Online pada Masa

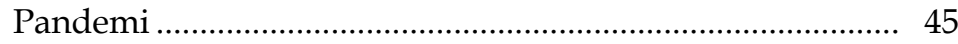


BAB IV

TANTANGAN PEMBELAJARAN E-LEARNING DIMASA

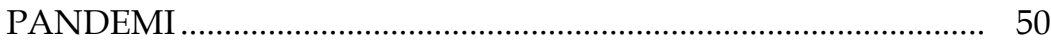

A. Proses Belajar Dari Rumah ................................................. 50

B. Tantangan Proses Belajar Dari Rumah ................................. 51

C. Tantangan E-Learning yang di Hadapi Universitas di Seluruh Dunia Akibat Wabah Covid-19 .............................. 53

D. Tantangan Proses Pembelajaran Daring di Sekolah dan Perguruan Tinggi.

BAB V

PERSEPSI GURU TERHADAP IMPLEMENTASI

E- LEARNING DI MASA COVID-19 ......................................... 63

A. Dampak Pandemik terhadap Siswa ...................................... 63

B. Dampak Pandemik terhadap Guru ........................................ 65

C. Persepsi Guru terhadap Kesiapan Institusi Pendidikan dalam Mengimplementasikan E-Learning .......................... 67

D. Gagasan-Gagasan Guru dalam Mengatasi Kendala Penerapan E-Learning

BAB VI

PEMANFAATAN APLIKASI BERBASIS TEKNOLOGI

DALAM PEMBELAJARAN DI MASA COVID-19........................ 70

A. Upaya Peningkatan Kualitas Proses Belajar dari Rumah... 71

B. Pemanfaatan E-Learning Di Sekolah Dasar ........................ 73

C. Pemanfaatan Aplikasi Pembelajaran di Sekolah Menengah dan Sekolah Menengah Atas (Studi Kasus di Maluku Utara) ………...................................................... 76

D. Pemanfaatan e-learning di Perguruan Tinggi..................... 78

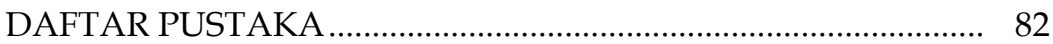

TENTANG PENULIS …………................................................ 96 


\section{PEMBELAJARAN E-LEARNING DI MASA PANDEMIK}

Balqis Husain, M.Pd.B.I

Megawati Basri, M.Pd 


\section{BAB I}

\section{PENDAHULUAN}

Pendidikan adalah usaha sadar dan sistematis, yang dilakukan orang-orang yang diserahi tanggung jawab untuk mempengaruhi peserta didik agar mempunyai sifat dan tabiat sesuai dengan cita-cita pendidikan (Achmad Munib, 2004). Oleh karena itu pendidikan diharapkan benar-benar diarahkan untuk menjadikan peserta didik mampu mencapai proses pendewasaan dan kemandirian. Kemajuan ilmu pengetahuan dan teknologi memiliki pengaruh yang sangat besar dalam berbagai bidang kehidupan manusia. Pendidikan sebagai salah satu bagian yang tidak terpisahkan dari proses pendewasaan manusia tentu di satu sisi memiliki andil yang besar bagi pengembangan ilmu pengetahuan dan teknologi tersebut, namun di sisi lain pendidikan juga perlu memanfaatkan kemajuan ilmu pengetahuan dan teknologi agar mampu mencapai tujuannya secara efektif dan efisien. Kemajuan ilmu pengetahuan dan teknologi telah berpengaruh terhadap penggunaan alat-alat bantu mengajar di sekolah-sekolah dan lembaga-lembaga pendidikan lainnya. Dewasa ini pembelajaran di sekolah mulai disesuaikan dengan perkembangan teknologi informasi, sehingga terjadi perubahan dan pergeseran paradigma pendidikan (Hujair, 2009). Hal ini mengindikasikan bahwa penggunaan teknologi informasi dalam proses pembelajaran di kelas, sudah menjadi suatu kebutuhan sekaligus tuntutan di era global ini. Guna meningkatkan efektivitas dan efisiensi pembelajaran, perlu dikembangkan berbagai model pembelajaran yang kreatif dan inovatif. Hal ini perlu dilakukan agar proses pembelajaran tidak terkesan kurang menarik, monoton dan membosankan sehingga akan menghambat terjadinya transfer of knowledge. Oleh karena itu, peran media dalam proses pembelajaran menjadi penting karena akan menjadikan proses pembelajaran tersebut menjadi lebih bervariasi dan tidak membosankan. Pada hakikatnya proses pembelajaran merupakan proses komunikasi atau penyampaian pesan dari pengantar ke penerima. Pesan berupa materi pelajaran yang 
dituangkan ke dalam simbol-simbol komunikasi baik verbal (katakata dan tulisan) maupun nonverbal. Pesan inilah yang akan ditangkap oleh peserta didik sebagai sebuah pengetahuan, keterampilan maupun nilai-nilai yang dapat digunakan dalam kehidupan sehari-hari. Agar pesan tersebut tersampaikan secara efektif tentu membutuhkan sarana atau media yang memadai. Dalam kenyataannya retensi siswa atau daya tangkap siswa sangat dipengaruhi oleh model aktivitas belajar yang dilakukan guru. Siswa hanya dapat menyerap $5 \%$ bahan pembelajaran apabila aktivitas ceramah dilakukan oleh guru dalam membelajarkan siswa. Sedangkan apabila aktivitas belajar dilakukan dengan teman sebaya, daya retensi siswa mencapai $90 \%$.

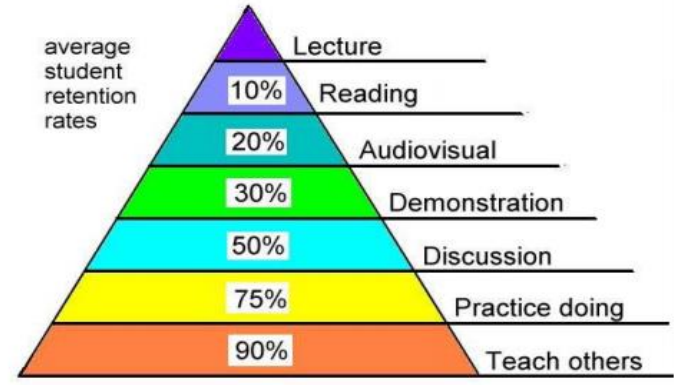

Penelitian Eyler dan Giles (dalam Widharyanto, 2003) membuktikan bahwa keefektifan pembelajaran dipengaruhi oleh media yang digunakan guru. Mereka menemukan bahwa model pembelajaran yang letaknya paling atas dalam kerucut, yakni pembelajaran yang hanya melibatkan simbol-simbol verbal melalui sajian teks adalah pembelajaran yang menghasilkan tingkat abstraksi paling tinggi. Pembelajaran yang paling efektif adalah pembelajaran yang berada pada dasar kerucut, yakni terlibat langsung dengan pengalamanpengalaman belajar yang bertujuan. Tingkat abstraksi pada model pembelajaran ini sangat rendah sehingga memudahkan siswa dalam menyerap pengetahuan dan keterampilan baru.

Menurut Depdiknas (2003) istilah media berasal dari bahasa Latin yang merupakan bentuk jamak dari "medium" yang secara 
harafiah berarti perantara atau pengantar. Makna umumnya adalah segala sesuatu yang dapat menyalurkan informasi dari sumber informasi kepada penerima informasi. Proses belajar mengajar pada dasarnya juga merupakan proses komunikasi, sehingga media yang digunakan dalam pembelajaran disebut media pembelajaran. Media pembelajaran merupakan bagian dari sumber belajar yang merupakan kombinasi antara perangkat lunak (bahan belajar) dan perangkat keras (alat belajar). Association for Education and Communication Technology (AECT), mengartikan kata media sebagai segala bentuk dan saluran yang dipergunakan untuk proses informasi. National Education Association (NEA) mendefinisikan media sebagai segala benda yang dapat dimanipulasikan, dilihat, didengar, dibaca atau dibicarakan beserta instrumen yang dipergunakan untuk kegiatan tersebut. Sedangkan HEINICH, dkk (1982) mengartikan istilah media sebagai "the term refers to anything that carries information between a source and a receiver". Sementara, Marshall McLuhan (dalam Oemar Hamalik, 2003: 201) berpendapat bahwa media adalah suatu ekstensi manusia yang memungkinkannya mempengaruhi orang lain yang tidak mengadakan kontak langsung dengan dia. Sesuai dengan rumusan ini, media komunikasi mencakup surat-surat, televisi, film dan telepon, bahwa jalan raya dan jalan kereta api merupakan media yang memungkinkan seseorang berkomunikasi dengan orang lain. Lebih lanjut Oemar Hamalik membedakan pengertian media menjadi dua yaitu dalam arti sempit dan dalam arti luas. Dalam arti sempit, media pengajaran hanya meliputi media yang dapat digunakan secara efektif dalam proses pengajaran yang terencana, sedangkan dalam artian luas, media tidak hanya meliputi media komunikasi elektronik yang kompleks, tetapi juga mencakup alatalat sederhana, seperti slide, fotografi, diagram, dan bagan buatan guru, objek-objek nyata, serta kunjungan ke luar sekolah. Sejalan dengan pandangan itu, guru-guru pun dianggap sebagai media penyajian, di samping radio dan televisi karena sama-sama membutuhkan dan menggunakan banyak waktu untuk menyampaikan informasi kepada siswa. Romiszowski (dalam 
Oemar Hamalik, 2003: 201) merumuskan media pengajaran "....as the carries of massages, from some transmitting source (which may be a human being or an intimate object), to the receiver of the massages (which is our case is the learner). Adapun Djamarah dan Aswan (2002: 136) mendefinisikan media sebagai alat bantu apa saja yang dapat dijadikan sebagai wahana penyalur informasi belajar atau penyalur pesan guna mencapai tujuan pembelajaran. Dalam konteks media sebagai sumber belajar, maka secara luas media dapat diartikan dengan manusia, benda, ataupun peristiwa yang memungkinkan peserta didik memperoleh pengetahuan dan ketrampilan. Pada hakikatnya berbagai batasan yang dikemukakan di atas mengandung pengertian dasar yang sama. Dalam berkomunikasi kita membutuhkan media atau sarana. Secara umum makna media adalah apa saja yang dapat menyalurkan informasi dari sumber Informasi ke penerima informasi. Jadi media pembelajaran merupakan "perangkat lunak" (Software) yang berupa pesan atau informasi pendidikan yang disajikan dengan memakai suatu peralatan bantu (Hardware) agar pesan/informasi tersebut dapat sampai kepada mahasiswa. Di sini jelas bahwa media berbeda dengan peralatan tetapi keduanya merupakan unsur-unsur yang saling terkait satu sama lain dalam usaha menyampaikan pesan/informasi pendidikan kepada mahasiswa. Dengan demikian dapat disimpulkan bahwa (a) media merupakan wadah dari pesan yang oleh sumber atau penyalurnya ingin diteruskan kepada sasaran atau penerima pesan tersebut, dan (b) bahwa materi yang ingin disampaikan adalah pesan pembelajaran, dan bahwa tujuan yang ingin dicapai adalah terjadinya proses belajar.

Setiap materi pembelajaran mempunyai tingkat kesukaran yang bervariasi. Pada satu sisi ada bahan pembelajaran yang tidak memerlukan media pembelajaran, tetapi di sisi lain ada bahan pembelajaran yang memerlukan media pembelajaran. Materi pembelajaran yang mempunyai tingkat kesukaran tinggi tentu sukar dipahami oleh siswa, apalagi oleh siswa yang kurang menyukai materi pembelajaran yang disampaikan. Keberadaan media pembelajaran sebagai alat bantu dalam proses pembelajaran 
merupakan suatu kenyataan yang tidak bisa dipungkiri. Guru sebagai penyampai pesan memiliki kepentingan yang besar untuk memudahkan tugasnya dalam menyampaikan pesan - pesan atau materi pembelajaran kepada peserta didik. Guru juga menyadari bahwa tanpa media, materi pembelajaran akan sulit untuk dapat dicerna dan dipahami oleh siswa, apalagi bila materi pembelajaran yang harus disampaikan tergolong rumit dan kompleks. Untuk itu penggunaan media mutlak harus dilakukan agar materi dapat sampai ke peserta didik secara efektif dan efisien. Secara umum, manfaat media dalam proses pembelajaran adalah memperlancar interaksi antara guru dan siswa sehingga kegiatan pembelajaran akan lebih efektif dan efisien. Tetapi secara khusus ada beberapa manfaat media yang lebih rinci. Kemp dan Dayton (dalam Depdiknas, 2003) mengidentifikasikan beberapa manfaat media dalam pembelajaran yaitu: 1) Penyampaian materi pelajaran dapat diseragamkan. 2) Proses pembelajaran menjadi lebih jelas dan menarik 3) Proses pembelajaran menjadi lebih interaktif 4) Efisiensi dalam waktu dan tenaga 5) Meningkatkan kualitas hasil belajar siswa 6) Media memungkinkan proses belajar dapat dilakukan di mana saja dan kapan saja 7) Media dapat menumbuhkan sikap positif siswa terhadap materi dan proses belajar 8) Mengubah peran guru ke arah yang lebih positif dan produktif. Selain beberapa manfaat media seperti yang dikemukakan di atas, masih terdapat beberapa manfaat praktis. Manfaat praktis media pembelajaran tersebut adalah: 1) Media dapat membuat materi pelajaran yang abstrak menjadi lebih konkret 2) Media juga dapat mengatasi kendala keterbatasan ruang dan waktu 3) Media dapat membantu mengatasi keterbatasan indera manusia. 4) Media dapat menyajikan objek pelajaran berupa benda atau peristiwa langka dan berbahaya ke dalam kelas. 5) Informasi pelajaran yang disajikan dengan media yang tepat akan memberikan kesan mendalam dan lebih lama tersimpan pada diri siswa. Berdasarkan beberapa pendapat di atas dapat disimpulkan bahwa secara praktis media pembelajaran memiliki beberapa manfaat, antara lain: 1) Mengkonkretkan konsep-konsep yang bersifat abstrak, sehingga dapat mengurangi 
verbalisme. Misalnya dengan menggunakan gambar, skema, grafik, model, dan sebagainya. 2) Membangkitkan motivasi, sehingga dapat memperbesar perhatian individual siswa untuk seluruh anggota kelompok belajar sebab jalannya pelajaran tidak membosankan dan tidak monoton. 3) Memfungsikan seluruh indera siswa, sehingga kelemahan dalam salah satu indera (misal: mata atau telinga) dapat diimbangi dengan kekuatan indera lainnya. 4) Mendekatkan dunia teori/konsep dengan realita yang sukar diperoleh dengan cara-cara lain selain menggunakan media pembelajaran. Misalnya untuk memberikan pengetahuan tentang pola bumi, anak tidak mungkin memperoleh pengalaman secara langsung. Maka dibuatlah globe sebagai model dari bola bumi. Demikian juga benda-benda lain yang terlalu besar atau terlalu kecil, gejala-gejala yang gerakannya terlalu cepat atau terlalu lambat, gejala-gejala/objek yang berbahaya maupun sukar didapat, hal-hal yang terlalu kompleks dan sebagainya, semuanya dapat diperjelas menggunakan media pembelajaran. 5) Meningkatkan kemungkinan terjadinya interaksi langsung antar siswa dengan lingkungannya. Misalnya dengan menggunakan rekaman, eksperimen, karyawisata, dan sebagainya. Memberikan uniformitas atau keseragaman dalam pengamatan, sebab daya tangkap setiap siswa akan berbeda-beda tergantung dari pengalaman serta intelegensi masing-masing siswa. Misalnya persepsi tentang gajah, dapat diperoleh uniformitas dalam pengamatan kalau binatang itu diamati langsung atau tiruannya saja dibawa ke depan kelas. 7) Menyajikan informasi belajar secara konsisten dan dapat diulang maupun disimpan menurut kebutuhan. Misalnya berupa rekaman, film, slide, gambar, foto, modul, dan sebagainya.

Berdasarkan kategori media, Paul dan David (1999) melalui Rishe (2007) berpendapat bahwa ada enam kategori, yaitu media yang tidak diproyeksikan, media yang diproyeksikan, media audio, media film dan video, multimedia, dan media berbasis komunikasi. Sementara, menurut Schramm mengkategorikan media dari dua segi: dari segi kompleksitas dan besarnya biaya dan menurut kemampuan daya liputannya. Briggs 
mengidentifikasikan tiga belas macam media pembelajaran yaitu objek, model, suara langsung, rekaman audio, media cetak, pembelajaran terprogram, papan tulis, media transparansi, film rangkai, film bingkai, film televise, dan film gambar. Gagne menyebutkan tujuh macam pengelompokkan media, yaitu benda untuk didemostrasikan, komunikasi lisan, media cetak, gambar diam, gambar gerak, film bersuara, dan mesin belajar. Menurut Edling, ada enam macam media pembelajaran yaitu kodifikasi subjektif visual, dan kodifikasi objektif audio, kodifikasi subjektif audio, dan kodifikasi objektif visual, pengalaman langsung dengan orang, dan pengalaman langsung dengan benda-benda. Soeparno (1988), berpendapat bahwa klasifikasi media dilakukan dengan menggunakan tiga unsur berdasarkan karakteristiknya, berdasarkan dimensi presentasinya, dan berdasarkan pemakaiannya. Bretz (dalam Hujair., 2009) mengidentifikasi ciri utama dari media menjadi tiga unsur pokok, yaitu suara, visual, dan gerak. Visual dibedakan menjadi tiga yaitu gambar, garis, dan simbol yang merupakan suatu kontinum dari bentuk yang dapat ditangkap dengan indera penglihatan. Di samping itu, Bretz juga membedakan antara media siar (telecommunication) dan media rekam (recording) sehingga terdapat delapan klasifikasi media: 1) media audio visual gerak, 2) media audio visual diam, 3) media audio visual semi gerak, 3) media visual gerak, 5) media visual diam, 6) media semi gerak, 7) media audio, dan 8) media cetak. Dengan menggunakan media pembelajaran secara tepat dan bervariasi dengan pengalaman suara (audio), penglihatan (visual), dan pengalaman gerakan dapat diatasi sikap pasif peserta didik dalam pembelajaran.

Dari berbagai ragam dan bentuk dari media pengajaran, pengelompokan atas media dan sumber belajar ekonomi dapat juga ditinjau dari jenisnya, yaitu media audio, media visual, media audio-visual, dan media serba neka. 1) media audio: radio, piringan hitam, pita audio, tape recorder dan telepon 2) media visual (a) media visual diam: foto, buku, ensiklopedia, majalah, surat kabar, buku referensi, dan barang hasil cetakan lain, gambar, ilustrasi, kliping, film bingkai, film rangkai, transparansi, mikrofis, 
overhead proyektor, grafik, bagan, diagram dan sketsa, poster, gambar kartun, peta dan globe (b) media visual gerak: film bisu 3) media audio-visual (a) media audiovisual diam: televisi diam, slide dan suara, film rangkai dan suara, buku dan suara. (b) Media audio visual gerak: video, $\mathrm{CD}$, film rangkai dan suara, televisi, gambar dan suara 4) media serba neka (a) papan dan display: papan tulis, papan pamer/pengumuman/majalah dinding, papan magnetic, whiteboard, mesin pengganda (b) Media tiga dimensi: realia, sampel, artifact, model, diorama, display (c) media teknik dramatisasi: drama, pantomim, bermain peran, demonstrasi, pawai/karnaval, pedalangan/panggung boneka, simulasi (d) sumber belajar pada masyarakat: kerja lapangan, studi wisata, perkemahan (e) belajar terprogram (f) computer.

Di era globalisasi dan informasi ini penggunaan media pembelajaran berbasis Teknologi Informasi (TI) menjadi sebuah kebutuhan dan tuntutan namun dalam implementasinya bukanlah merupakan hal yang mudah. Dalam menggunakan media tersebut harus memperhatikan beberapa teknik agar media yang dipergunakan itu dapat dimanfaatkan dengan maksimal dan tidak menyimpang dari tujuan media tersebut. Arief S. Sadiman, dkk (2006) mengatakan bahwa ditinjau dari kesiapan pengadaannya, media dikelompokkan dalam dua jenis, yaitu media jadi karena merupakan komoditi perdagangan yang terdapat di pasaran luas dalam keadaan siap pakai (media by utilization) dan media rancangan yang perlu dirancang dan dipersiapkan secara khusus untuk maksud dan tujuan pembelajaran tertentu. Dari pernyataan tersebut di atas dapat dikategorikan bahwa media Komputer dan LCD Proyektor meupakan media rancangan yang di dalam penggunaannya sangat diperlukan perancangan khusus dan didesain sedemikian rupa agar dapat dimanfaatkan. Perangkat keras (hardware) yang difungsikan dalam menginspirasikan media tersebut adalah menggunakan satu unit komputer lengkap yang sudah terkoneksikan dengan LCD Proyektor. Dengan demikian media ini hendaknya menarik perhatian siswa dalam proses pembelajaran. Teknologi jaringan komputer/internet memberi manfaat bagi pemakainya untuk melakukan komunikasi secara 
langsung dengan pemakai lainnya. Hal ini dimungkinkan dengan diciptakannya sebuah alat bernama modem. Jaringan komputer/internet memberi kemungkinan bagi pesertanya untuk melakukan komunikasi tertulis dan saling bertukar pikiran tentang kegiatan belajar yang mereka lakukan. Jaringan komputer dapat dirancang sedemikian rupa agar dosen dapat berkomunikasi dengan mahasiswa dan mahasiswa dapat melakukan interaksi belajar dengan mahasiswa yang lain. Interaksi pembelajaran dengan menggunakan jaringan komputer tidak saja dapat dilakukan secara individual, tetapi juga untuk menunjang kegiatan belajar kelompok. Pemanfaatan jaringan komputer dalam sistem pendidikan jarak jauh dikenal juga dengan istilah Computer Conferencing System (CCF). Biasanya sistem ini dilakukan melalui surat elektronik atau E-mail. Beberapa kelebihan pemanfaatan jaringan komputer dalam sistem pendidikan jarak jauh yaitu: dapat memperkaya model-model tutorial, dapat memecahkan masalah belajar yang dihadapi mahasiswa dalam waktu yang lebih singkat dan dapat mengatasi hambatan ruang dan waktu dalam memperoleh informasi. CCF memberi kemungkinan bagi mahasiswa dan dosen untuk melakukan interaksi pembelajaran langsung antar individu, individu dengan kelompok, dan kelompok dengan kelompok (Mason, 1994 dalam Benny A. Pribadi dan Tita Rosita, 2002:13-14) 


\section{BAB II}

\section{E-LEARNING}

Diawal tahun 2020, penyebaran dan penularan Virus Corona semakin merebak diseluruh penjuru dunia. Pandemik yang awal penularannya berasal dari Wuhan ini terus meluas dan tak terkendali. Penularan yang cepat dan massive mengakibatkan perubahan system disegala aspek, baik dari aspek sosial, ekonomi, maupun pendidikan. Tak terkecuali dengan Indonesia. Untuk menghindari penyebaran pandemi ini, berbagai upaya telah dilakukan oleh pemerintah untuk meminimalisir percepatan pergerakan virus Corona. Upaya-upaya yang dilakukan baik berupa pembatasan sosial berskala besar (PSBB) sampai dengan kenormalan baru atau yang dikenal dengan new normal era.

Sejak adanya pandemi, sistem pembelajaran di dunia pendidikan mengalami perubahan yang sangat signifikan. Pemerintah secara tegas mengeluarkan keputusan untuk menerapkan pembelajaran jarak jauh dengan memanfaatkan teknologi secara serentak agar proses belajar mengajar tetap berlangsung. Yang menjadi pertanyaan adalah apakah seluruh institusi pendidikan siap akan perubahan sistem pendidikan saat ini? Bagaimana dengan daerah-daerah pedalaman maupun daerah kepulauan yang seperti diketahui bersama bahwa layanan koneksi internetnya sangat buruk? Bagaimana dengan kesiapan sumber daya manusianya? Apakah sudah melek teknologi atau masih berkutat dengan pola interaksi tradisional? Tentunya hal ini menjadi PR bersama baik institusi, pemerintah, maupun orang tua untuk mencari solusi dari permasalahan tersebut.

\section{A. Pengertian E-Learning}

Tak dapat dipungkiri bahwa beberapa tahun terakhir pembelajaran berbasis teknologi (E-learning) mulai mendapatkan perhatian khusus dari berbagai instituasi pendidikan maupun pelaku pendidikan di Indonesia. (Zhou et al., 2020) e-learning atau pembelajaran berbasis online merupakan model pembelajaran yang mendorong pengguna (siswa/guru/instruktur) memanfaatkan platform teknologi 
infomasi dan komunikasi dalam proses belajar mengajar. Sejalan dengan yang dikemukakan oleh Arif \& Wahyu (2014) bahwa E-learning merupakan metode belajar mengajar dengan menggunakan sebuah sistem sebagai media belajar mengajar yang terhubung oleh jaringan. Talebian et al., (2014) menekankan bahwa untuk mendorong terjadinya pembelajaran berbasis online, tenaga pengajar maupun siswa harus memanfaatkan platform pembelajaran yang sesuai dengan kebutuhan maupun kondisi pengguna tersebut. Bahkan Sulisworo et al., (2016) dan Zhou et al., (2020) sepakat bahwa pembelajaran berbasis teknologi membawa banyak manfaat dan sesuai dengan era saat ini yakni era teknologi 4.0.

Istilah e-learning banyak memiliki arti karena bermacam penggunaan e-learning Saat ini. Pada dasarnya, e-learning memiliki dua tipe yaitu synchronous dan asynchronous. Synchronous berarti pada waktu yang sama. Proses pembelajaran terjadi pada saat yang sama antara pendidik dan peserta didik. Hal ini memungkinkan interaksi langsung antara pendidik dan peserta didik secara online. Dalam pelaksanaan, synchronous training mengharuskan pendidik dan peserta didik mengakses internet secara bersamaan. Pendidik memberikan materi pembelajaran dalam bentuk makalah atau slide presentasi dan peserta didik dapat mendengarkan presentasi secara langsung melalui internet. Peserta didik juga dapat mengajukan pertanyaan atau komentar secara langsung ataupun melalui chat window. Synchronous training merupakan gambaran dari kelas nyata, namun bersifat maya (virtual) dan semua peserta didik terhubung melalui internet. Synchronous training sering juga disebut sebagai virtual classroom. Asynchronous berarti tidak pada waktu bersamaan. Peserta didik dapat mengambil waktu pembelajaran berbeda dengan pendidik pada saat memberikan materi. Asynchronous training popular dalam e-learning karena peserta didik dapat mengakses materi pembelajaran dimanapun dan kapanpun. Peserta didik dapat melaksanakan pembelajaran dan menyelesaikannya setiap saat sesuai rentang jadwal yang sudah ditentukan. 
Pembelajaran dapat berbentuk bacaan, animasi, simulasi, permainan edukatif, tes, quis dan pengumpulan tugas (Hartanto, 2016).

Proses pembelajaran berbasis e-learning menjadi pilihan untuk mengatasi keterbatasan fasilitas pendidikan. Proses pembelajaran dengan e-learning tidak kalah efektif jika dibandingkan dengan pembelajaran di ruang kelas karena dalam pembelajaran e-learning antara pengajar dan peserta didik dapat berinteraksi secara langsung (synchronous) dengan fitur video/audio conference atau pesan singkat (chats); maupun berinteraksi secara tidak langsung (asynchronous) dengan forum diskusi (Arif \& Wahyu, 2014). Inovasi ini mendorong sektor pendidikan memasuki sebuah jaman yang benar-benar baru yang ditandai oleh kemampuan masyarakat dalam membentuk sebuah peradaban baru yang begitu tergantung pada (teknologi) informasi dan berbagai kegiatan (yang menjadi) maya.

Kegiatan pendidikan tinggi yang begitu sulit untuk dijangkau, kaku, tertutup, kurang motivasi, dan tidak bersahabat, kini dengan penggunaan internet yang dikenal sebagai e-learning menjadi pilihan dan merupakan sumber belajar dalam menghadapi tantangan masa depan. Melalui $e$ learning, proses pembelajaran dapat berlangsung di mana pun juga. Guru dan murid, dosen dan mahasiswa, tutor dan tutee (peserta tutorial) tidak perlu lagi bertemu tatap muka di dalam ruang kuliah. Ada beberapa hal yang menjadi pertimbangan mengapa e-learning diadopsi dan diimplementasikan, antara lain karena e-learning merupakan cara yang relatif cepat untuk mendistribusikan bahan ajar dan materi e-learning juga dapat diperbaharui dengan cepat. E-learning juga dapat diakses oleh lebih dari satu user. Meskipun demikian, tidak semua user dapat akses ke jaringan internet karena beberapa hal seperti ketersediaan piranti keras (komputer) atau karena persyaratan dalam enrollment (Darmayanti et al., 2007). 


\section{B. Jenis-Jenis E-Learning}

Ada beragam cara untuk mengklasifikasikan jenis $e$ learning. Menurut Algahtani (2011), e-learning diklasifikasikan berdasarkan sejauh mana keterlibatan mereka dalam pendidikan. Beberapa klasifikasi juga didasarkan pada waktu interaksi. E-learning dibagi menjadi dua jenis dasar, yang terdiri dari e-learning berbasis komputer dan berbasis internet. Pembelajaran berbasis komputer terdiri dari penggunaan berbagai perangkat keras dan perangkat lunak, umumnya tersedia dalam penggunaan Teknologi Informasi dan Komunikasi (TIK) dan juga setiap komponen dapat digunakan melalui dua cara yakni instruksi yang dikelola komputer dan pembelajaran dengan bantuan komputer. Pembelajaran berbantukan komputer dimana komputer digunakan sebagai media pendukung metode tradisional, dengan menyediakan perangkat lunak interaktif sebagai alat pendukung dalam kelas atau sebagai alat untuk belajar mandiri di luar kelas. Namun, pada instruksi yang dikelola komputer, komputer dipekerjakan untuk tujuan menyimpan dan mengambil informasi untuk membantu dalam pengelolaan pendidikan (Valentina \& Abaidoo Nelly, 2015).

Pembelajaran berbasis internet menurut Almosa (2001) adalah peningkatan lebih lanjut dari pembelajaran berbasis komputer, Pembelajaran ini bertujuan membuat konten yang tersedia di internet, dengan kesiapan tautan ke sumber pengetahuan terkait. Misalnya layanan e-mail dan referensi yang dapat digunakan oleh peserta didik kapan saja dan di mana saja serta ketersediaan atau tidak adanya guru atau instruktur. Zeitoun (2008) mengklasifikasikan sejauh mana fitur fitur tersebut digunakan dalam pendidikan. Terdapat tiga model pembelajaran e-learning, yaitu; pembelajaran campuran (Blended learning), model pendampingan (Assistant Mode), dan model pembelajaran online sepenuhnya (Completely Online Mode). model pendampingan (Assistant Mode) melengkapi metode tradisional sesuai kebutuhan. Pembelajaran campuran (Blended learning) menggabungkan model pembelajaran online, 
offline serta memasukkan model pembelajaran tradisional di dalamnya. Model pembelajaran online sepenuhnya (Completely Online Mode), merupakan pengembangan yang paling lengkap, dimana model ini melibatkan penggunaan jaringan eksklusif untuk belajar (Zeitoun, 2008).

Algahtani (2011) menggambarkan mode online sepenuhnya sebagai "synchronous" atau "asynchronous" dengan menerapkan pilihan waktu interaksi. Pemilihan waktu dengan menggunakan mode synchronous terdiri dari akses alternatif online antara guru atau instruktur dan peserta didik, atau antar peserta didik. Mode synchronous memungkinkan semua peserta untuk mengirim komunikasi ke peserta lain melalui internet (Algahtani, 2011; Almosa dan Almubarak, 2005). Jenis synchronous memungkinkan peserta didik untuk berdiskusi dengan instruktur dan juga antar peserta didik melalui internet pada saat yang sama dengan penggunaan alat-alat seperti konferensi video dan ruang obrolan. Jenis ini menurut Almosa dan Almubarak (2005) menawarkan manfaat dengan umpan balik seketika. Mode asynchronous juga memungkinkan peserta didik untuk berdiskusi dengan instruktur atau guru serta antar peserta didik melalui internet pada waktu yang berbeda. Meskipun tidak adanya interaksi di waktu yang sama tetapi kemudian, dengan penggunaan alat-alat seperti diskusi utas dan e-mail. Manfaat dari model pembelajaran ini bahwa peserta didik dapat belajar pada waktu, situasi dan kondisi yang sesuai dengan mereka sementara kerugiannya yakni bahwa peserta didik tidak dapat menerima umpan balik seketika itu juga dari instruktur serta dari rekan pelajar (Almosa dan Almubarak, 2005).

\section{Model Penyelenggaraan E- Learning}

Adawi (2016) e-learning memungkinkan pembelajaran tidak hanya berlangsung secara formal di kelas, tetapi dengan bantuan peralatan komputer dan jaringan, para siswa dapat secara aktif dilibatkan dalam proses belajar mengajar, dalam suatu bentuk sistem pembelajaran jarak jauh tanpa terkendala 
oleh kondisi geografis, ruang dan waktu, berikut ini di paparkan 2 model dari banyak model penyelenggaraan $e$ learning dalam pembelajaran:

1. Model e-Learning tutorial

Model ini telah diaplikasikan oleh Universitas Terbuka Online, berdasarkan jenis aplikasi komunikasi yang di dilakukan dapat di bagi lagi menjadi dua, yaitu (a) Tutorial e-learning dengan memanfaatkan aplikasi e-mail internet dan (b) Tutorial dengan memanfaatkan aplikasi faxinternet.

a. Bimbingan belajar elektronik memanfaatkan aplikasi email Internet.

Sistem belajar berbasis Internet yang dapat dikembangkan dapat berupa suatu sistem yang memanfaatkan aplikasi Internet yang bernama mailinglist. Pada tutorial via Internet ini pengajar akan membahas materi atau tugas secara tertulis dan kemudian tulisan tersebut didistribusikan pada seluruh mahasiswa melalui email. Untuk kemudian, ketika mahasiswa membuka Internet dan memeriksa surat elektronik/ emailnya, maka mereka dapat membaca tulisan pengajar serta memberi jawaban, komentar ataupun mengajukan pertanyaan terhadap tugas yang diberikan

b. Tutorial Elektronik via Fax-Internet

Integrasi Fax-Internet dalam sistem bimbingan belajar via Internet ini akan memperluas titik akses bagi peserta didik. Dalam konsep tutorial Fax-Internet, peserta didik mengirim atau menerima pesan melalui fax dan pengajar/ guru akan menerima atau mengirim balasan surat tersebut melalui email. Ketika menerima fax dari peserta didik, pengajar atau guru menerima fax tersebut dalam bentuk attachment (lampiran) pada surat elektronik 
2. Model Computer Supported Collaboration Learning

Collaboration didefinisikan sebagai kerjasama antar peserta dalam rangka mencapai tujuan bersama. Collaboration tidak hanya sekedar menempatkan para peserta ke dalam kelompok-kelompok studi, tetapi diatur pula bagaimana mengkoordinasikan mereka supaya bisa bekerjasama dalam studi. Saat ini penelitian di bidang kolaborasi melalui internet dikenal dengan istilah CSCL (Computer Supported Collaborative Learning), dimana pada prinsipnya CSCL berusaha untuk mengoptimalkan pengetahuan yang dimiliki oleh para peserta dalam bentuk kerjasama dalam pemecahan masalah. Kenyataannya kolaborasi antar peserta cenderung lebih mudah dibandingkan dengan kolaborasi antara peserta dengan guru. Pemakai terdiri dari siswa dan guru yang membimbing, dimana siswa itu sendiri terbagi menjadi siswa dan siswa lain yang bertindak sebagai collaborator selama proses belajar. Para peserta saling berkolaborasi dengan tool yang tersedia melalui jaringan intranet atau internet, dimana guru mengarahkan jalannya kolaborasi supaya mencapai tujuan yang di inginkan, sebagaimana yang diharapkan, untuk melakukan kerjasama antar siswa dalam pemecahan masalah yang berkaitan dengan materi pelajaran. Kolaborasi ini bisa diwujudkan dalam bentuk diskusi atau tanya-jawab dengan memanfaatkan fasilitas internet yang umum dipakai misalnya: e-mail, chatting, dikembangkan sesuai dengan kebutuhan aplikasi yang akan dibuat. Dalam pelaksanaan sistem e-learning, kolaborasi antar siswa akan menjadi faktor yang essensial, terutama pada sistem asynchronous dimana para siswa tidak secara langsung bisa mengetahui kondisi siswa lain, sehingga seandainya terjadi masalah dalam memahami makalah yang disediakan, akan terjadi kecenderungan untuk gagal mengikutinya dikarenakan kurangnya komunikasi antar siswa, sehingga timbul kecenderungan terperangkap pada 
kondisi standstill, sehingga menyebabkan hasil yang tidak diharapkan.

Adawi (2016) Ada 5 hal essensial yang harus diperhatikan dalam menjalankan kolaborasi lewat internet, yaitu sebagai berikut:

a. Clear, positive interdependence among students (Jelas/bersih, hal positif interdependece antar para siswa).

b. Regular group self-evaluation (evaluasi diri kelompok secara reguler).

c. Interpersonal behaviors that promote each member'slearning and success (perilaku hubungan antar pribadi yangmempromosikan masing-masing sukses dan pelajaran anggota).

d. Individual accountability and personal responsibility (tanggung-jawab individu dan tanggung jawab pribadi).

e. Frequent use of appropriate interpersonal and small groupsocial skills (penggunaan yang sering dari kelompokkecil dan hubungan antar pribadi sesuai ketrampilan sosial).

Dalam proses kolaborasi antar siswa, guru bisa saja terlibat didalamnya secara tidak langsung, dalam rangka membantu proses kolaborasi dengan cara memberikan arahan berupa message untuk memecahkan masalah. Sehingga diharapkan proses kolaborasi menjadi lebih lancar. Beberapa perangkat yang diperlukan untuk menjalankan metode CSCL adalah: Database, untuk menyimpan materi pelajaran dan record-record yang berkaitan dengan proses belajar-mengajar khususnya proses kolaborasi. Web Server, merupakan bagian mengatur akses ke sistem dan mengatur tampilan yang diperlukan dalam proses pendidikan. Termasuk pula pengaturan keamanan sistem. Pengembang aplikasi seperti ini bisa dilakukan dengan menggunakan software sebagai berikut : Platform Open Source Linux Web Server Apache+Tomcat Programming Java Script Java Server Page Database MySQL / Postgress Frame Work Struts 
Development Tool Eclipse. Keuntungan menggunakan software diatas yaitu seluruhnya merupakan Open Source yang bisa di download secara gratis dari web site masing-masing, sehingga dalam implementasinya bisa ditekan biaya serendah mungkin, tanpa mengurangi realibilitas sistem itu sendiri. Keuntungan lainnya yaitu untuk akses ke sistem seperti ini tidak tergantung pada suatu platform operating system. Oleh karena itu, dengan penerapan berbagai Software Open Source seperti ini, diharapkan akan dicapai suatu sistem e-learning yang aman, terpercaya, performance tinggi, multiplatform, dan biaya rendah (Adawi, 2016).

\section{Batasan E-learning}

Cepatnya perkembangan teknologi informasi dan komunikasi (Information and Communication Technology, ICT) memungkinkan adanya penggunaan media elektronik seperti komputer dalam menyebarkan informasi. Di dalam bidang pendidikan, perkembangan ICT ini memicu berkembangnya $e$ learning. E-learning atau electronic learning adalah sebuah konsep dalam proses pembelajaran dengan menggunakan ICT, khususnya menggunakan media yang berbasis Internet. Istilah e-learning sendiri memiliki kesamaan makna dengan beberapa istilah lain seperti on-line learning, virtual classroom dan virtual learning. Sedangkan batasan dari e-learning sendiri, seperti yang terdapat yang dikemukakan oleh Churchill (2005) terdiri dari lima hal berikut ini.

1. Perpaduan antara Internet dengan konsep pembelajaran, atau pembelajaran yang menggunakan Internet.

2. Penggunaan teknologi jaringan (Web) untuk menciptakan, menumbuhkan, menyebarluaskan, dan memudahkan proses pembelajaran tanpa terikat oleh waktu dan tempat.

3. Upaya membentuk (sikap) seseorang agar tidak individualistik, berwawasan luas, dinamis dalam belajar, mampu mengembangkan pengetahuan, serta menjadi pembelajar dan praktisi yang mampu mengembangkan keahlian. 
4. Upaya mengembangkan akuntabilitas, meningkatkan kecerdasan, dan memberikan kesempatan bagi individu dan organisasi untuk tetap mengikuti perkembangan jaman melalui dunia Internet.

5. Suatu kekuatan yang membuat individu maupun organisasi untuk berkompetisi dan memberikan kesempatan kepada mereka untuk tetap mengikuti perubahan ekonomi secara global.

\section{E. Fungsi Pembelajaran Berbasis E-Learning dan Jaringan}

Adawi (2016) Setidaknya ada 3 (tiga) fungsi pembelajaran Berbasis Komputer dan Jaringan terhadap kegiatan pembelajaran di dalam kelas (classroom instruction), yaitu sebagai suplement yang sifatnya pilihan/opsional, pelengkap (complement), atau pengganti (substitution) (Siahaan, 2002).

1. Tambahan (suplement)

Dikatakan berfungsi sebagai tambahan (supplement), apabila peserta didik mempunyai kebebasan memilih, apakah akan memanfaatkan materi pembelajaran elektronik atau tidak. Dalam hal ini, tidak ada kewajiban/ keharusan bagi peserta didik untuk mengakses materi pembelajaran elektronik. Sekalipun sifatnya opsional, peserta didik yang memanfaatkannya tentu akan memiliki tambahan pengetahuan atau wawasan.

2. Pelengkap (complement)

Dikatakan berfungsi sebagai pelengkap (complement) apabila materi pembelajaran elektronik diprogramkan untuk melengkapi materi pembelajaran yang diterima siswa di dalam kelas (Lewis, 2002). Sebagai pelengkap berarti materi pembelajaran elektronik diprogramkan untuk menjadi materi pengayaan (reinforcement) atau perbaikan (remedial) bagi peserta didik di dalam mengikuti kegiatan pembelajaran konvensional. Materi pembelajaran elektronik dikatakan sebagai enrichment, apabila kepada peserta didik 
yang dapat dengan cepat menguasai/memahami materi pelajaran yang disampaikan guru secara tatap muka (fast learners) diberikan kesempatan untuk mengakses materi pembelajaran elektronik yang memang secara khusus dikembangkan untuk mereka. Tujuannya agar semakin memantapkan tingkat penguasaan peserta didik terhadap materi pelajaran yang disajikan guru di dalam kelas. Dikatakan sebagai program remedial, apabila kepada peserta didik yang mengalami kesulitan memahami materi pelajaran yang disajikan guru secara tatap muka di kelas (slow learners) diberikan kesempatan untuk memanfaatkan materi pembelajaran elektronik yang memang secara khusus dirancang untuk mereka. Tujuannya agar peserta didik semakin lebih mudah memahami materi pelajaran yang disajikan guru di kelas.

\section{Pengganti (substitution)}

Beberapa sekolah/ perguruan tinggi di negara-negara maju memberikan beberapa alternatif model kegiatan pembelajaran/perkuliahan kepada para peserta didiknya. Tujuannya agar para peserta didik dapat secara fleksibel mengelola kegiatan perkuliahannya sesuai dengan waktu dan aktivitas lain sehari-hari mahasiswa. Ada 3 alternatif model kegiatan pembelajaran yang dapat dipilih peserta didik, yaitu:

a. Sepenuhnya secara tatap muka (konvensional)

b. Sebagian secara tatap muka dan sebagian lagi melalui internet, atau bahkan

c. Sepenuhnya melalui internet.

Alternatif model pembelajaran mana pun yang akan dipilih mahasiswa tidak menjadi masalah dalam penilaian. Karena ketiga model penyajian materi perkuliahan mendapatkan pengakuan atau penilaian yang sama. Jika peserta didik dapat menyelesaikan program perkuliahannya dan lulus melalui cara konvensional atau sepenuhnya melalui 
Internet, atau bahkan melalui perpaduan kedua model ini, maka institusi penyelenggara pendidikan akan memberikan pengakuan yang sama. Keadaan yang sangat fleksibel ini dinilai sangat membantu mahasiswa untuk mempercepat penyelesaian perkuliahannya.

\section{F. Penggunaan Teknologi Informasi dan Komunikasi (TIK) di Dunia Pendidikan}

Talebian et al (2014) Teknologi informasi dan komunikasi terdiri dari perangkat keras, perangkat lunak, jaringan dan media untuk mengumpulkan, menyimpan, memproses, mengirimkan dan menyajikan informasi (suara, data, teks dan gambar) serta layanan terkait. TIK dapat dibagi menjadi dua komponen: Information and Communication Infrastructure (ICI) dan Information Technology (IT). Yang pertama mengacu pada sistem telekomunikasi fisik dan jaringan (Seluler, suara, surat, radio dan televisi) sementara yang terakhir mengacu pada perangkat keras dan perangkat lunak pengumpulan informasi, penyimpanan, pemrosesan dan presentasi (Sarkar, 2012).

Menurut UNESCO (2002) TIK sekarang menembus lingkungan pendidikan dan mendukung keberhasilan pendidikan abad ke-21. TIK juga menambah nilai pada proses pembelajaran dan organisasi serta pengelolaan lembaga pembelajaran. Teknologi adalah kekuatan pendorong di balik pesatnya perkembangan dan inovasi di negara maju dan berkembang.

TIK dianggap sebagai arus utama dalam pendidikan tinggi. TIK saat ini digunakan di berbagai bidang seperti: mengembangkan materi kursus; memberikan konten dan berbagi konten; komunikasi antara peserta didik, guru dan dunia luar; penciptaan dan pengiriman presentasi dan kuliah; penelitian akademik; dukungan administratif dan pendaftaran mahasiswa (Mandal \&amp; Mete, 2012). Ketika menerapkan TIK dalam pendidikan tinggi, pembelajaran tidak lagi terbatas pada penyusunan jadwal (Hattangdi \& Ghosh, 2008). 
Dalam konteks ini, e-learning menggunakan fasilitas TIK. Penggunaan e-learning telah meningkat tidak hanya kecepatan mentransfer pengetahuan, tetapi juga metode mentransfer dari satu orang ke orang lain. E-learning adalah tentang filosofi dan metodologi pembelajaran dan pengajaran dalam konteks pendidikan berbasis hasil. Talebian et al (2014) melakukan studi tentang penggunaan TIK di perguruan tinggi di Iran mengungkapkan bahwa penerapan E-learning di Iran masih sangat dini dan hanya ada beberapa program online. Sejarah penggunaan e-learning di Iran saat ini belum melebihi 13 tahun. E-learning diperkenalkan oleh sektor swasta dan organisasi pemerintah. Di Iran sendiri terdapat banyak universitas virtual atau pusat-pusat seperti Universitas Teheran, Amirkabir University of Technology, Iran University of Science and Technology, Sharif University of Technology, Shiraz Virtual University dan beberapa perguruan tinggi virtual Islam dan pusat-pusat seperti pusat-pusat Islam dan Sekolah Sains Hadits yang memanfaatkan e-learning (Ghasem Tabar, 2010).

\section{G. Institusi Penyelenggara E-Learning}

Adawi (2016) Konsep pembelajaran dengan menggunakan Komputer dan Jaringan memungkinkan proses pengembangan pengetahuan tidak hanya terjadi di dalam ruangan kelas saja dimana guru secara terpusat memberikan pelajaran secara searah, tetapi dengan bantuan peralatan komputer dan jaringan, para siswa dapat secara aktif dilibatkan dalam proses belajar-mengajar. Mereka bisa terus berkomunikasi dengan sesamanya kapan dan dimana saja dengan cara akses ke sistem yang tersedia secara online. Sistem seperti ini tidak saja akan menambah pengetahuan seluruh siswa, akan tetapi juga akan turut membantu meringankan beban guru dalam proses belajar-mengajar, karena dalam sistem ini beberapa fungsi guru dapat diambil alih dalam suatu program komputer. Disamping itu, hasil dari proses dan hasil dari belajar-mengajar bisa disimpan datanya di dalam bentuk database, yang bisa dimanfaatkan untuk mengulang kembali 
proses belajar-mengajar yang lalu sebagai rujukan, sehingga bisa dihasilkan sajian materi pelajaran yang lebih baik lagi. Sebagai bagian dari perkembangan e-learning, Web merupakan salah satu teknologi internet yang telah berkembang sejak lama dan yang paling umum dipakai dalam pelaksanaan pendidikan dan latihan jarak jauh (e-learning) tersebut.

Adawi (2016) Di Indonesia, kalaupun perkembangan pemanfaat konsep ini terbilang berjalan lamban, Dengan fasilitas jaringan yang dimiliki oleh berbagai lembaga pendidikan atau institusi di Indonesia baik Intranet maupun internet, sebenarnya sudah sangat mungkin untuk diterapkannya sistem pendukung e-learning berbasis Web dengan menggunakan sistem synchronous atau asynchronous, secara mandiri atau digabungkan, walaupun pada dasarnya kedua sistem diatas biasanya digabungkan untuk menghasilkan suatu sistem yang lebih efektif karena masingmasing memiliki kelebihan dan kekurangannya. Dibeberapa negara yang sudah maju dengan kondisi infrastruktur jaringan kecepatan tinggi akan sangat memungkinkan penerapan teknologi multimedia secara real time seperti video conference untuk kepentingan aplikasi e-learning, tetapi untuk kondisi umum di Indonesia dimana infrastruktur jaringannya masih relatif terbatas akan mengalami hambatan dan menjadi tidak efektif. Namun demikian walaupun tanpa teknologi multimedia tersebut, sebenarnya dengan kondisi jaringan Internet yang ada sekarang di Indonesia sangat memungkinkan, terutama dengan menggunakan sistem asynchronous ataupun dengan menggunakan sistem synchronous seperti chatting yang disesuaikan dengan sistem pendukung pendidikan yang akan dikembangkan. Beberapa di antara institusi penyelenggara e-learning dapat dikemukakan sebagai berikut:

1. University of Phoenix Online merupakan universitas virtual yang paling sukses di Amerika Serikat. University of Phoenix Online ini mempunyai 37.569 mahasiswa dari 78.700 mahasiswa keseluruhan, 38 kampus, dan 78 pusat- 
pusat kegiatan belajar yang tersebar di Amerika Serikat, Kanada, dan Puerto Rico. Di samping itu, Universitas ini telah meluluskan 10.000 mahasiswa sedangkan Universitas Virtual swasta lainnya di Amerika hanya mampu meluluskan jauh di bawahnya.

2. Jones International University merupakan salah satu perguruan tinggi yang juga tercatat berhasil dalam menyelenggarakan e-Learning. Universitas ini mempunyai 6,000 mahasiswa yang belajar secara online.

3. United Kingdom Open University (UKOU) merupakan universitas terbesar penyelenggara kegiatan pembelajaran elektronik di dunia dengan 215,000 mahasiswa.

4. The College of Business at the University of Tennesse memulai perkuliahan khusus secara e-Learning kepada 400 dokter yang bekerja di ruang gawat darurat di seluruh negara bagian Amerika Serikat dan di 11 negara lainnya. Perguruan tinggi yang menyelenggarakan program setahun untuk MBA bagi para dokter dengan menggunakan elearning dan tatap muka.

5. Universiti Tun Abdul Razak (UNITAR) merupakan universitas yang pertama di Malaysia maupun di kawasan Asia Tenggara yang menyajikan perkuliahan secara elektronik (e-learning). Perkuliahan elektronik ini mulai diselenggarakan oleh UNITAR pada tahun 1998.

6. Universitas Terbuka (UT) telah melaksanakan ujicoba penyelenggaraan Tutorial Elektronik (Tutel) pada tahun 1999 bagi para mahasiswanya. Alasan dilakukannya ujicoba tutorial elektronik ini adalah sesuai dengan kebutuhan mahasiswa untuk membantu mereka memecahkan kesulitan yang dihadapi selama belajar mandiri.

7. Universitas Gajah Mada (UGM) telah memulai mempersiapkan kegiatan pembelajaran yang memanfaatkan internet untuk program pascasarjana di bidang pengelolaan rumah sakit dan pengelolaan layanan kesehatan pada tahun 1996. 
8. Florida Virtual School merupakan salah satu dari Sekolah Menengah di Amerika Serikat yang telah berkembang pesat dalam penyelenggaraan pembelajaran elektronik. Pada tahun kelima, Sekolah Menegah ini menerima 3.505 siswa dengan mempekerjakan sekitar 41 guru secara penuh waktu dan 27 guru lainnya secara paruh waktu. Yang menjadi motto sekolah adalah "kapan saja, di mana saja, melalui jalur mana saja, dengan kecepatan apapun."

\section{H. Pemanfaatan E-Learning di Dunia Pendidikan}

Valentina \& Abaidoo Nelly (2015) Perkembangan teknologi multimedia dan informasi, serta penggunaan internet sebagai teknik pengajaran baru, telah membuat perubahan radikal dalam proses pengajaran tradisional (Wang et al. 2007). Perkembangan teknologi informasi, menurut Yang dan Arjomand (1999), telah menghasilkan lebih banyak pilihan untuk pendidikan saat ini. Agenda sekolah dan lembaga pendidikan telah mengakui e-learning memiliki prospek untuk mengubah orang, pengetahuan, keterampilan dan kinerja (Henry, 2001). Sama halnya dengan apa yang dikemukakan oleh Love and Fry (2006), perguruan tinggi, universitas, dan lembaga pendidikan tinggi lainnya berlomba-lomba untuk memajukan kemampuan pembelajaran online dalam pengembangan pasar pendidikan cyber. E-learning, telah menjadi sangat penting dalam lembaga pendidikan tinggi. Pengenalan dan perluasan berbagai perlengkapan e-learning telah mengalami beberapa perubahan di lembaga pendidikan tinggi, terutama pada saat proses pengiriman dan dukungan pendidikan (Dublin, 2003).

Sama halnya dengan berbagai jenis e-learning, terdapat juga perbedaan teknik penggunaan e-learning dalam dunia pendidikan. Algahtani, (2011), dalam evaluasinya tentang efektivitas dan pengalaman pembelajaran e-learning di Arab Saudi, menemukan tiga model yang berbeda penggunaan $e$ learning dalam pendidikan termasuk "pembelajaran campuran (blended Learning) dan online learning". Adapun tiga cara 
penggunaan teknologi e-learning seperti yang ditemukan oleh Algahtani (2011) dijelaskan di bawah ini.

"Blended learning adalah situasi di mana e-Learning digunakan sebagai media pembelajaran pendamping di kelas tradisional yang memberikan kemandirian relatif kepada peserta didik atau siswa (Algahtani, 2011). Dalam blended elearning, Algahtani (2011) dan Zeitoun (2008) menjelaskan bahwa, dengan cara menggunakan e-learning ini, penyampaian materi dan penjelasan kursus dibagi antara metode pembelajaran tradisional dan metode e-learning dalam pengaturan kelas. Yang ketiga adalah pembelajaran berbasis online tanpa partisipasi belajar tradisional atau partisipasi kelas. Dalam bentuk penggunaan ini, penggunaan e-learning dilakukan secara total sehingga ada kemandirian maksimal dari peserta didik atau siswa (Algahtani, 2011; Zeitoun, 2008). Zeitoun (2008) telah menjelaskan lebih lanjut bahwa model online dibagi menjadi pembelajaran individu dan kolaboratif, di mana pembelajaran kolaboratif juga terdiri dari pembelajaran synchronous dan asynchronous.

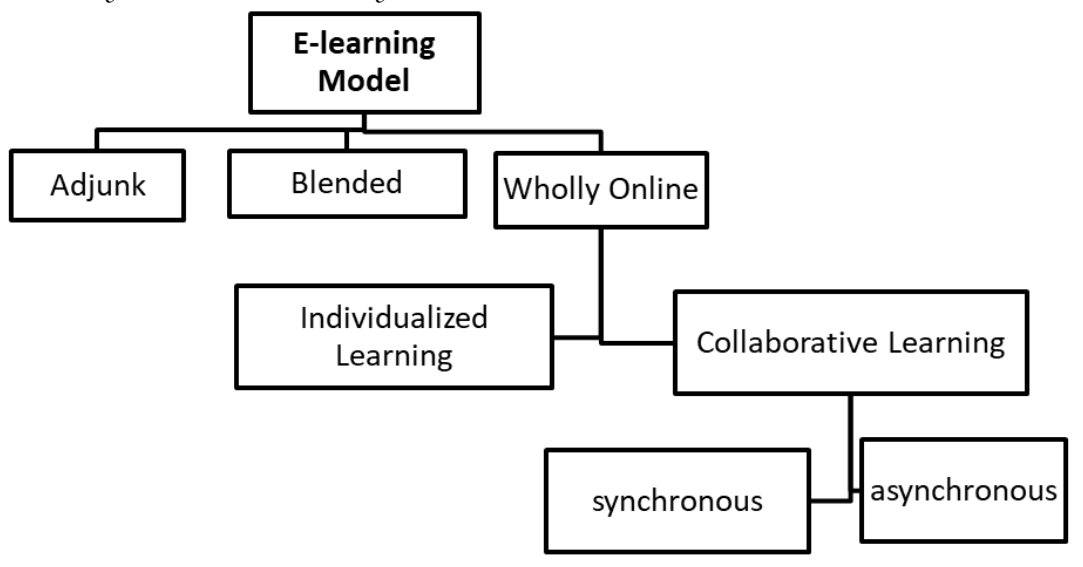

(Valentina \& Abaidoo Nelly, 2015)

Gambar 1. Model E-learning dalam Dunia Pendidikan 


\section{Perbedaan Paradigma Lama dan Paradigma Baru Tentang E- Learning Pada Pendidikan Tinggi}

Paradigma baru yang muncul terkait dengan proses pembelajaran yang tidak lagi menggambarkan pertemuan tatap muka di dalam kelas, meskipun konsep interaksi sosial di dalamnya tetap dipertahankan, kini telah diterima secara luas dan telah begitu mempengaruhi dan berdampak pada kehidupan manusia. Kehadiran teknologi Internet memudahkan orang untuk melakukan interaksi tanpa terikat oleh ruang dan waktu lagi (Darmayanti et al., 2007). Berikut adalah tabel perbedaan paradigma lama dan paradigma baru pada perguruan tinggi terkait dengan penerapan $e$-learning.

Tabel 1. Perbedaan Paradigma Lama dan Paradigma Baru pada Pendidikan Tinggi

\begin{tabular}{lll}
\hline \multicolumn{1}{c}{$\begin{array}{c}\text { Paradigma lama pendidikan } \\
\text { Tinggi }\end{array}$} & \multicolumn{2}{c}{$\begin{array}{c}\text { Paradigma baru pendidikan } \\
\text { Tinggi }\end{array}$} \\
\hline $\begin{array}{l}\text { Mata kuliah sesuai yang } \\
\text { diberikan }\end{array}$ & $\begin{array}{l}\text { Memilih matakuliah sesuai } \\
\text { keinginan }\end{array}$ \\
\hline $\begin{array}{l}\text { Registrasi dan kegiatan } \\
\text { akademik sangat tergantung } \\
\text { pada kalender akademik }\end{array}$ & $\begin{array}{l}\text { Registrasi dan kegiatan } \\
\text { akademik terbuka sepanjang } \\
\text { tahun }\end{array}$ \\
\hline $\begin{array}{l}\text { Universitasnya berada di lokasi } \\
\text { tertentu }\end{array}$ & $\begin{array}{l}\text { Universitasnya bersifat maya } \\
\text { Lama kuliah dibatasi perolehan } \\
\text { gelar }\end{array}$ & Belajar sepanjang hayat \\
\hline Umur berkisar 18-25 tahun & $\begin{array}{l}\text { Umur mulai 18 tahun sampai } \\
\text { tak terbatas }\end{array}$ \\
\hline $\begin{array}{l}\text { Tergantung pada kegiatan } \\
\text { institusinya }\end{array}$ & \begin{tabular}{l} 
Tergantung penilaian pasar \\
\hline Keluaran/produknya \\
tunggal bersifat
\end{tabular} & $\begin{array}{l}\text { Informasi yang diperoleh } \\
\text { dapat digunakan ulang }\end{array}$ \\
\hline $\begin{array}{l}\text { Mahasiswa diperlakukan sebagai } \\
\text { objek }\end{array}$ & $\begin{array}{l}\text { Mahasiswa dianggap sebagai } \\
\text { konsumen }\end{array}$ \\
\hline $\begin{array}{l}\text { Pembelajaran dilakukan } \\
\text { dalam kelas }\end{array}$ & $\begin{array}{l}\text { Pembelajaran dapat dilakukan } \\
\text { dimanapun juga }\end{array}$ \\
\hline
\end{tabular}




\begin{tabular}{|c|c|}
\hline Bersifat multikultur & Bersifat global \\
\hline $\begin{array}{l}\text { Konsepnya merupakan satu } \\
\text { kesatuan yang besar }\end{array}$ & $\begin{array}{l}\text { Konsepnya kecil dan terpilah- } \\
\text { pilah }\end{array}$ \\
\hline Single discipline & Multi-disiplin \\
\hline Terfokus pada institusi & Terfokus pada pasar \\
\hline Dibiayai pemerintah & $\begin{array}{l}\text { Dibiayai melalui } \\
\text { masyarakat }\end{array}$ \\
\hline $\begin{array}{l}\text { Teknologi merupakan investasi } \\
\text { yang mahal }\end{array}$ & $\begin{array}{l}\text { Teknologi sebagai } \\
\text { pembeda }\end{array}$ \\
\hline
\end{tabular}

perubahan dari konsep pembelajaran tatap muka menuju konsep e-learning juga menuntut mahasiswa untuk mengatasi berbagai kendala yang muncul karena konsep e-learning, yang merupakan konsep baru dengan nilai-nilai baru di dalamnya, harus mereka adopsi. Sama halnya dengan berbagai kesulitan yang dihadapi oleh para dosen, untuk jangka panjang, para mahasiswa terbiasa dengan lingkungan belajar di mana dosen adalah seseorang yang dianggap mengetahui segala hal dan akan memberitahu bilamana dan apa yang harus dilakukan mahasiswa. Di dalam e-learning, mahasiswa dapat mengidentifikasi, mengenali, dan membuat keputusan sendiri mengenai kemajuan belajar yang telah direncanakannya. Mahasiswa juga harus belajar bagaimana cara berkomunikasi melalui Internet. Pengalaman menunjukkan bahwa banyak dosen atau tutor yang menerapkan konsep e-learning justru bersikap apriori dengan menyatakan bahwa mahasiswa sulit menerima (konsep) e-learning karena mereka tidak terbiasa berkomunikasi menggunakan komputer sebagai media komunikasinya (Darmayanti et al., 2007). Adapun perbedaan pembelajaran tatap muka dan pembelajaran e-learning dapat dilihat pada tabel di bawa ini; 
Tabel 2. Perbedaan Pembelajaran Konvensional dan Pembelajaran E-learning

\begin{tabular}{|c|c|}
\hline Pembelajaran Tatap Muka & Pembelajaran dengan e-Learning \\
\hline $\begin{array}{ll}\text { Pembelajaran } & \text { dilakukan } \\
\text { secara tatap muka } & \end{array}$ & $\begin{array}{l}\text { Menggunakan sistem belajar } \\
\text { jarak jauh }\end{array}$ \\
\hline $\begin{array}{l}\text { Interaksi antara dosen dan } \\
\text { mahasiswa dilakukan secara } \\
\text { tatap muka dalam konsep } \\
\text { maya }\end{array}$ & $\begin{array}{l}\text { Interaksi antara dosen dan } \\
\text { mahasiswa dilakukan melalui } \\
\text { media Terfokus pada mahasiswa }\end{array}$ \\
\hline Peran dosen sangat dominan & $\begin{array}{l}\text { Mahasiswa sangat berperan } \\
\text { dalam kemajuan/keberhasilan } \\
\text { belajarnya }\end{array}$ \\
\hline $\begin{array}{l}\text { Kemajuan belajar tergantung } \\
\text { pada dosen }\end{array}$ & \\
\hline $\begin{array}{l}\text { Dosen dan mahasiswa harus } \\
\text { bertemu pada saat/waktu } \\
\text { yang sama }\end{array}$ & $\begin{array}{l}\text { Dosen dan mahasiswa tidak } \\
\text { harus bertemu pada saat/waktu } \\
\text { yang sama }\end{array}$ \\
\hline $\begin{array}{l}\text { Dosen sangat berperan dalam } \\
\text { proses belajar mahasiswa }\end{array}$ & $\begin{array}{l}\text { Menerapkan konsep belajar } \\
\text { mandiri }\end{array}$ \\
\hline $\begin{array}{l}\text { Karena tatap muka, maka } \\
\text { kedua belah pihak harus } \\
\text { memiliki } \\
\text { berkomunikasi dalam konteks } \\
\text { tatap muka }\end{array}$ & $\begin{array}{l}\text { Dibutuhkan } \\
\text { berkomunikasi dengan bahasa } \\
\text { tulis }\end{array}$ \\
\hline $\begin{array}{l}\text { Bagi dosen, khususnya, harus } \\
\text { memiliki kemampuan } \\
\text { berbicara di depan kelas }\end{array}$ & $\begin{array}{l}\text { Kedua belah pihak dituntut } \\
\text { untuk memiliki kemampuan } \\
\text { dalam menggunakan media/ } \\
\text { komputer dan jaringan komputer } \\
\text { (internet) }\end{array}$ \\
\hline
\end{tabular}

Dalam pandangan tradisional, konsep pembelajaran di perguruan tinggi selalu digambarkan melalui pertemuan tatap muka antara dosen dan mahasiswa yang berlangsung di dalam kelas. Paradigma baru yang muncul menunjukkan bahwa pembelajaran tidak lagi merujuk pada pertemuan tatap muka -meskipun konsep interaksi sosial di dalamnya tetap 
dipertahankan-- tetapi dilakukan melalui Internet. Kehadiran teknologi Internet, yang memudahkan orang untuk melakukan interaksi tanpa terikat oleh ruang dan waktu, mendorong sektor pendidikan memasuki sebuah era baru memanfaatkan $e$ learning. Melalui e-learning, proses pembelajaran dapat berlangsung di mana pun juga dan kapanpun dikehendaki. 


\section{BAB III}

MANFAAT E-LEARNING DI MASA PANDEMI

\section{A. Manfaat E-Learning Bagi Perguruan Tinggi}

Manfaat e-learning bagi dunia pendidikan secara umum, yaitu:

1. Fleksibilitas tempat dan waktu, jika pembelajaran konvensional di kelas mengharuskan siswa untuk hadir di kelas pada jam-jam tertentu, maka e learning memberikan fleksibilitas dalam memilih waktu dan tempat untuk mengakses pelajaran.

2. Independent learning, e-learning memberikan kesempatan bagi pembelajar untuk memegang kendali atas kesuksesan belajar masing-masing, artinya pembelajar diberi kebebasan untuk menentukan kapan akan mulai, kapan akan menyelesaikan, dan bagian mana dalam satu modul yang ingin dipelajarinya terlebih dulu. Jika peserta didik mengalami kesulitan, mereka bisa mengulang-ulang lagi sampai merasa mampu memahami pelajaran tersebut. Pembelajar juga bisa menghubungi instruktur, narasumber melalui email atau mengikuti dialog interaktif pada waktuwaktu tertentu. Banyak yang merasa cara belajar independen seperti ini lebih efektif daripada cara belajar lainnya yang memaksakannya untuk belajar dengan urutan yang telah ditetapkan.

3. Biaya, banyak biaya yang bisa dihemat dari cara pembelajaran dengan e-learning. Secara finansial, biaya yang bisa dihemat, antara lain biaya transportasi ke tempat belajar dan akomodasi selama belajar, biaya administrasi pengelolaan, penyediaan sarana dan fasilitas fisik untuk belajar.

4. Fleksibilitas kecepatan pembelajaran, e-learning dapat disesuaikan dengan kecepatan belajar masing-masing siswa. Apabila peserta didik belum mengerti dan memahami modul tertentu, maka peserta didik dapat mengulanginya lagi sampai mereka paham. 
5. Standarisasi pengajaran, pelajaran melalui e-learning selalu memiliki kualitas yang sama setiap kali diakses dan tidak tergantung suasana hati pengajar.

6. Efektifitas pengajaran, penyampaian pelajaran e-learning dapat berupa simulasi dan kasus-kasus, menggunakan bentuk permainan dan menerapkan teknologi animasi canggih.

7. Kecepatan distribusi, e-learning dapat dengan cepat menjangkau ke seluruh penjuru, tim desain hanya perlu mempersiapkan bahan pelajaran secepatnya dan menginstal hasilnya di server pusat $e$-learning.

8. Ketersediaan On-Demand, e-learning dapat diakses sewaktuwaktu.

9. Otomatisasi proses administrasi, e-learning menggunakan suatu Learning Management System (LMS) yang berfungsi sebagai platform pelajaran-pelajaran e-learning. LMS berfungsi pula menyimpan data-data pelajar, pelajaran, dan proses pembelajaran yang berlangsung.

Dengan demikian penerapan e-learning di perguruan tinggi diharapkan dapat memberikan manfaat antara lain, (1) Adanya peningkatan interaksi mahasiswa dengan sesamanya dan dengan dosen, (2) Tersedianya sumber-sumber pembelajaran yang tidak terbatas, (3) E-learning yang dikembangkan secara benar akan efektif dapat meningkatkan kualitas lulusan dan kualitas perguruan tinggi, (4) Terbentuknya komunitas pembelajar yang saling berinteraksi, saling memberi dan menerima serta tidak terbatas dalam satu lokasi, (5) Meningkatkan kualitas dosen karena dimungkinkan menggali informasi secara lebih luas dan bahkan tidak terbatas (Hartanto, 2016).

E-learning bertujuan untuk menghindari kendala linear kurikulum tradisional. Selain itu, proses belajar mengajar dapat dilakukan di pusat pelatihan, rumah dan bahkan daerah terpencil dengan tujuan membangun kesempatan untuk belajar (Behnam, 2012). Talebian et al (2014) melakukan penelitian 
terkait penggunaan ICT di perguruan tinggi di Iran mengungkapkan beberapa manfaat e-learning untuk Pendidikan pertanian Iran seperti di bawah ini:

1. Waktu dan tempat akses: Pengguna dapat mengakses $e$ learning melalui program pelatihan sesuai dengan kecepatan akses internet dan tempat mereka sendiri. Mereka juga dapat mengakses sistem pelatihan kapan saja, dan menerima sebanyak yang mereka butuhkan (James, 2002).

2. Persamaan hak: Karimi (2007) percaya bahwa e-learning memberikan kesempatan kepada mahasiswa pertanian untuk memberikan akses perguruan tinggi di setiap situasi. Akses yang sama dan kompetensi yang sama adalah tujuan dari sistem pendidikan ini.

3. Meningkatkan kolaborasi grup: Pelajar dan guru dapat dihubungkan bersama melalui obrolan, konferensi suara dan video, TV interaktif, kelas virtual, dan menghilangkan pemisahan fisik secara bersamaan. Dengan cara ini, peserta didik aktif dalam proses belajar dan interaktif (Faraj Allahi \& Zarif Sanayei, 2009).

4. Akses langsung ke banyak sumber daya pelatihan lainnya: Karimi (2007) menyatakan jumlah salinan buku atau majalah terbatas. Oleh karena itu, perpustakaan digital menawarkan salinan elektronik sehingga peserta didik akan dapat mengakses dan menggunakannya di mana saja.

5. Meningkatkan dimensi internasional layanan pendidikan: Peserta didik dapat mengetahui informasi yang diperlukan di bidangnya dengan menggunakan ICT dan data yang diperoleh tidak hanya terbatas pada informasi tentang Bahasa Persia tetapi juga dalam bahasa Inggris (Khaleghi, 2010).

6. Menentukan tingkat perkembangan dalam pembelajaran: Fitur ini mengurangi tingkat kecemasan peserta didik yang kurang mampu bersaing dengan peserta didik lainnya dan juga meningkatkan kepuasan peserta didik yang berbakat melalui sistem pendidikan ini (Hodavand, 2008). 
Talebian et al (2014) Ketika teknologi informasi dan komunikasi berhasil dikombinasikan dengan pendidikan, hal ini merupakan kesempatan bagi individu untuk mempercepat kecepatan belajar dan menghasilkan seseorang sebagai pembelajar aktif yang independen. Fitur-fitur ini meliputi:

1. Memungkinkan akses yang lebih besar ke lebih banyak siswa yang lebih efisiensi dengan informasi yang lebih baik: Pelajar dengan akses Internet dapat mengakses perpustakaan online, jurnal, konferensi dan kelas virtual online. Melalui kemudahan akses tersebut maka perolehan informasi akan lebih luas dan cepat. (Faraj Allahi \& Zarif Sanayei, 2009; Markovic, 2010; ^ Sarkar, 2012).

2. Menawarkan kombinasi pendidikan sambil menyeimbangkan kehidupan keluarga dan pekerjaan: Menurut Bjork, OttossonandThorsteinsdottir (2008) para peserta dapat berpartisipasi dan menyelesaikan jam pelajaran sesuai dengan keperluan sehari-hari mereka. Hal ini menjadikan pendidikan e-learning sebagai pilihan yang berharga bagi mereka yang memiliki pekerjaan lain, seperti keluarga atau pekerjaan yang tidak dapat dengan mudah untuk dilepaskan atau ditinggalkan.

3. Biaya perjalanan dan penghematan waktu: Karimi (2007) menyatakan penurunan biaya perjalanan ini pada akhirnya menyebabkan penurunan biaya pendidikan secara bertahap.

4. Akses lebih mudah ke pendidikan tinggi: Metode pendidikan ini sesuai untuk peserta didik yang tidak dapat menempuh pendidikan tinggi dikarenakan tidak diterima di universitas karena kapasitas yang terbatas.

5. Lintas platform: Pelatihan berbasis web dapat diakses melalui penjelajahan web dan perangkat lunak pada platform apa pun seperti windows, MAC, UNIX, dll. Pada dasarnya, pengguna dapat memberikan kursus pelatihan mdengan menggunakan berbagai model mesin melalui Internet tanpa harus mengembangkan pembelajran yang berbeda untuk setiap platform (James, 2002). 
Beberapa penelitian mengungkapkan manfaat dari $e$ learning karena kemampuannya untuk fokus pada kebutuhan peserta didik. Misalnya Marc (2000) dalam ulasan bukunya tentang strategi $e$-learning guna mentransfer pengetahuan di era digital mencatat bahwa salah satu keunggulan e-learning dalam dunia pendidikan yakni fokusnya pada kebutuhan peserta didik sebagai faktor penting dalam proses pendidikan (bukan pada kebutuhan instruktur atau lembaga pendidikan). Berikut adalah beberapa manfaat menggunakan e-learning dalam dunia pendidikan yang diperoleh dari beberapa review literatur:

1. E-learning memberikan fleksibilitas tanpa harus mempertimbangkan masalah waktu dan tempat. Setiap siswa memiliki kesempatan dalam memilih tempat dan waktu yang sesuai dengan kondisinya. Menurut Smedley (2010), penggunaan e-learning memberikan fleksibilitas baik waktu dan tempat pengiriman atau penerimaan pembelajaran kepada lembaga pendidikan serta siswa atau peserta didik.

2. E-learning meningkatkan pengembangan pengetahuan dan kualifikasi melalui kemudahan ke sejumlah besar akses informasi.

3. Memberikan kesempatan komunikasi dan interaksi yang lebih baik antara peserta didik dengan menggunakan forum diskusi. Melalui e-learning, membantu menghilangkan hambatan yang berpotensi menghambat partisipasi termasuk takut berbicara dengan peserta didik lain. Elearning memotivasi siswa untuk berinteraksi dengan orang lain, serta bertukar pendapat dan menghormati sudut pandang yang berbeda. E-learning memudahkan komunikasi dan juga meningkatkan hubungan yang mendukung pembelajaran. Wagner et al (2008) mencatat bahwa e-learning memiliki beberapa fitur tambahan yang bertujuan untuk menunjang interaksi antara siswa dan guru selama pengiriman konten.

4. E-learning memfasilitasi keefektifan biaya dalam artian bahwa tidak perlu bagi siswa atau peserta didik untuk 
bepergian. E-learning menawarkan kesempatan pada peserta didik untuk belajar secara maksimal tanpa perlu menggunakan banyak infrastruktur seperti bangunan sekolah.

5. E-learning selalu mempertimbangkan perbedaan belajar peserta didik. Beberapa pelajar misalnya lebih memilih untuk berkonsentrasi pada bidang-bidang keahlian tertentu, sementara yang lain dapat mengambil seluruh mata pelajaran yang diinginkan.

6. E-learning membantu mengimbangi kelangkaan staf akademik, termasuk instruktur atau guru serta fasilitator, teknisi laboratorium dll.

7. Penggunaan e-learning memungkinkan untuk belajar secara berulang-ulang. Misalnya cara pembelajaran asynchronous memungkinkan setiap siswa untuk belajar sesuai dengan daya tangkap terhadap materi karena pembelajaran asynchronous tidak memberikan batasan waktu dalam belajar dan sesuai dengan kecepatan koneksi internet sehingga materi dapat dipelajari secara berulang-ulang. Oleh karena itu, e-learning dapat meningkatkan kepuasan dan dipercaya dapat mengurangi stres (Codone, 2001; Amer, 2007; Urdan dan Weggen, 2000; Algahtani, 2011; Marc, 2002; Klein dan Ware, 2003).

\section{B. Manfaat E-Learning di Masa Penyebaran Wabah Covid-19}

Verawardina et al., (2020) mengulas beberapa manfaat penerapan e-learning di masa pandemi;

1. Bagi siswa, fleksibilitas belajar siswa dapat terjadi secara bebas dan luas tanpa dibatasi oleh ruang, jarak dan waktu, termasuk penyebaran virus corona atau covid-19 yang berhubungan langsung dengan interaksi. Namun, dengan menggunakan pembelajaran online, guru dan siswa tetap dapat berinteraksi secara online melalui diskusi, pertanyaan dan jawaban serta lainnya melalui forum chat dan penugasan. 
2. Bagi Guru, mereka dapat menciptakan efektivitas, fleksibilitas kegiatan belajar mengajar meskipun ada kewaspadaan wabah virus corona atau covid-19. Memudahkan tenaga pendidik untuk memperbarui materi pengajaran. Guru sebagai fasilitator dan mentor dalam pembelajaran. Guru dapat mengontrol kegiatan belajar siswa dalam e-learning sehingga guru dapat mengetahui apa yang dilakukan oleh siswa mengenai waktu penggunaan $e$ learning, topik atau materi yang dipelajari, serta mengetahui kegiatan apa yang dilakukan.

3. Pembelajaran online dapat dilakukan kapan saja meskipun ada wabah covid-19 sehingga pembelajaran lebih fleksibel.

Menurut Sadikin \& Hamidah (2020) pembelajaran daring yang dilaksanakan di Program Studi Pendidikan Biologi FKIP Universitas Jambi dalam upaya memutus mata rantai penyebaran Covid-19 menggunakan aplikasi-aplikasi pembelajaran yang dapat diakses dengan jaringan internet. Secara keseluruhan, mahasiswa puas dengan pembelajaran yang fleksibel. Dengan pembelajaran daring, mahasiswa tidak terkendala waktu dan tempat dimana mereka dapat mengikuti perkuliahan dari rumah masing-masing maupun dari tempat dimana saja. Dengan pembelajaran daring, dosen memberikan perkuliahan melalui kelas-kelas virtual yang dapat diakses dimana pun dan kapan pun tidak terikat ruang dan waktu. Kondisi ini membuat mahasiswa dapat secara bebas memilih mata kuliah yang dikuti dan tugas mana yang harus dikerjakan lebih dahulu. Penelitian Sun et al., (2008) menginformasikan bahwa fleksibilitas waktu, metode pembelajaran, dan tempat dalam pembelajaran daring berpengaruh terhadap kepuasan mahasiswa terhadap pembelajaran.

Sadikin \& Hamidah (2020) ditemukan hasil penelitian yang unik dari penelitian ini yaitu mahasiswa merasa lebih nyaman dalam mengemukakan gagasan dan pertanyaan dalam pembelajaran daring. Mengikuti pembelajaran dari rumah membuat mereka tidak merasakan tekanan psikologis dari 
teman sebaya yang biasa mereka alami ketika mengikuti pembelajaran tatap muka. Ketidakhadiran dosen secara langsung atau fisik juga menyebabkan mahasiswa merasa tidak canggung dalam mengutarakan gagasan. Ketiadaaan penghambat fisik serta batasan ruang dan waktu menyebabkan peserta didik lebih nyaman dalam berkomunikasi (Sun et al., 2008). Lebih lanjut, pembelajaran secara daring menghilangkan rasa cangung yang pada akhirnya membuat mahasiswa menjadi berani berekpresi dalam bertanya dan mengutarakan ide secara bebas.

Pembelajaran daring juga memiliki kelebihan mampu menumbuhkan kemandirian belajar (self regulated learning). Penggunaan aplikasi online mampu meningkatkan kemandiri belajar (Oknisih, N., \& Suyoto, S., 2019). Kuo et al., (2014) menyatakan bahwa pembelajaran daring lebih bersifat berpusat pada siswa yang menyebabkan mereka mampu memunculkan tanggung jawab dan otonomi dalam belajar (learning autuonomy). Belajar secara daring menuntut mahasiswa mempersiapkan sendiri pembelajarannya, mengevaluasi, mengatur dan secara simultan mempertahankan motiviasi dalam belajar Sun (2014); Aina, M (2016); Sobron, A. N., \& Bayu, R. (2019) menyatakan bahwa pembelajaran daring dapat meningkatkan minat peserta didik.

\section{Implementasi E-learning dalam Menghadapi Wabah Covid-19}

Menghadapi merebaknya virus Covid-19 yang menyebar luas dan meningkatkan kesadaran masyarakat untuk menghindari Covid- 19, sehingga salah satu masalah yang muncul adalah mengurangi kontak interaksi langsung di sekolah, dan pembelajaran dialihkan secara online. Dalam hal ini, guru harus mampu memposisikan diri dalam memanfaatkan e-learning. (Verawardina et al., 2020) berikut menjelaskan apa yang harus dipertimbangkan dalam penerapan pembelajaran online:

1. Menyiapkan fasilitas untuk menjalankan pembelajaran online seperti portal pembelajaran online berbasis web, dapat 
menggunakan learning management systems (LMS) seperti Moodle, Dokeos, atau platform yang telah tersedia seperti Edmodo, Google Classroom, rumah belajar Kementerian Pendidikan dan Kebudayaan, ruang guru dan lain-lain yang dapat digunakan secara open source. Ketika membutuhkan komputer, laptop atau ponsel dan jaringan internet, sebagai pendukung dapat menggunakan webcam (kamera) untuk interaksi visual, mikrofon untuk berbicara menggunakan audio. Kemudian menyesuaikan kebutuhan komponen yang terdapat dalam e-learning seperti instruksional, chat, forum, video conferencing, dan link (Verawadina et al., 2020). Menyusun kurikulum pembelajaran daring di era Revolusi Industri 4.0 diperlukan sinergi yang melibatkan pemerintah, lembaga pendidikan, dan industri untuk merevitalisasi kurikulum yang relevan khususnya di era revolusi industri 40. Kurikulum yang relevan juga harus dipertimbangkan dalam penerapan pembelajaran menggunakan teknologi. (Hendriyani et al., 2020). Oleh karena itu, dalam pembelajaran online aplikasi ini sejalan dengan kurikulum saat ini. Selain itu, ada juga kebutuhan untuk pedoman pembelajaran online untuk memudahkan guru dan siswa tentang apa yang perlu dilakukan dan apa yang harus diakses. Pembelajaran online mengharuskan peserta untuk sepenuhnya dilatih dengan teknologi. Hal ini karena pembelajaran online menggunakan pengembangan teknologi canggih dan kontemporer. Misalnya, mengharuskan peserta untuk terbiasa dengan alat pembelajaran, alat konferensi, dan alat diskusi yang tersedia dalam sistem pembelajaran online. Perangkat keras dan perangkat lunak yang diinstal pada sistem komputer untuk peserta harus kompatibel dengan sistem dan perangkat lunak yang digunakan oleh guru melalui jarak jauh (Kayimbaşioğlu, Oktekin, \& Haci, 2016).

2. Guru dalam pembelajaran online dapat memilih untuk menggunakan berbagai model, metode, strategi, teknik sebagai desainer dan pelaksana pembelajaran. Selain itu, 
juga dapat diatur pengaturan pembelajaran sinchronous dan asinchronous sesuai kebutuhan. Pembelajaran online juga dapat dikemas sesuai dengan gaya belajar siswa (Verawardina, 2017). Dalam pembelajaran online, guru juga berperan sebagai fasilitator dan motivator sehingga siswa aktif dalam proses pembelajaran yang efektif dan optimal. Guru harus memiliki keterampilan dalam menggunakan teknologi (Feladi et al., 2020; Bandri at al, 2020; Ahmad \& Ahmad, 2019). Lima kompetensi yang harus dipersiapkan oleh guru untuk memasuki Revolusi Industri 4.0, seperti kompetensi pendidikan, kompetensi komersialisasi teknologi, kompetensi globalisasi, kompetensi dalam strategi masa depan, dan kompetensi konselor (Wahyuni, 2018). Dari kompetensi tersebut, guru harus mampu membekali diri untuk meningkatkan kompetensinya, yang dimaksudkan dalam menghadapi pembelajaran online yang harus memiliki kompetensi di bidang teknologi.

3. Membuat instruksi pembelajaran menjadi jelas, terutama mengenai jadwal pembelajaran online, menjelaskan ruang lingkup pembelajaran seperti standar kompetensi, kompetensi dasar, tujuan dan prestasi. Pada bagian ini, instruksi diwijibkan untuk disampaikan secara jelas bagi siswa, berapa lama dan apa yang harus dilakukan dalam pembelajaran online.

4. Menyiapkan materi pengajaran dengan menyajikan konten materi, terutama pembelajaran teoritis dan praktis. Untuk pembelajaran teori, guru dapat membuat materi pengajaran yang mudah dipahami dalam bentuk gambar, animasi, persentase power point, multimedia interaktif, dalam bentuk e-book, pdf, doc dan format materi lainnya. Sedangkan untuk pembelajaran praktis, konten materi dapat dilakukan melalui video tutorial, simulasi interaktif, Virtual Laboratories, dan langsung dipraktekkan melalui konferensi video.

5. Kegiatan melalui fasilitas interaksi dapat dilakukan melalui fasilitas chat, forum diskusi, dan konferensi video untuk 
interaksi audio visual dengan adanya gambar dan audio yang relevan secara langsung. Kegiatan lain melalui sumber belajar lainnya, misalnya, menautkan ke situs pembelajaran yang relevan seperti perpustakaan digital. Hal ini juga dapat memanfaatkan kegiatan portofolio, glosarium, dan lain-lain sebagai dukungan.

6. Sistem evaluasi, dalam pembelajarani online ketersediaan bank pertanyaan yang dapat digunakan oleh guru untuk mengevaluasi siswa. Juga disediakannya kumpulan soalsoal latihan untuk mengukur kemampuan siswa. Dalam sistem evaluasi pembelajaran online, harus jelas apakah tes online, misalnya, dapat menggunakan tes kognitif pilihan ganda, esai, pencocokan, melalui fasilitas Kuis yang terdapat dalam sistem e-learning. Selain mengevaluasi melalui proyek- proyek, yang kemudian dibuat untuk mengirim proyek melalui fasilitas penugasan baik dalam bentuk dokumen maupun video, di sini guru dapat memberikan penilaian secara langsung terhadap hasil penugasan.

7. Penerapan pembelajaran online dimana lembaga pendidikan dan guru harus mampu memberikan sosialisasi penggunaan e-learning bagi guru dan siswa lainnya. Penting untuk memotivasi siswa untuk dapat belajar secara mandiri melalui pembelajaran online, guru harus ekstra keras untuk menekankan pengulangan sosialisasi dan motivasi dalam pelaksanaan awal pembelajaran online. Peran guru juga harus mampu melakukan fasilitator dan memantau siswa.

Hasil interview yang dilakukan di Universitas Pasifik Morotai dengan melibatkan tenaga pengajar dan mahasiswa yang berasal dari berbagai disiplin ilmu. Hal ini dapat dilihat keterlibatan terbanyak berasal dari responden Fakultas Pelatihan dan Pendidikan Guru dengan peserta 48,6\%. Kemudian diikuti oleh responden Matematika dan Ilmu Pengetahuan Alam dan responden Teknik dengan masingmasing 14,3\%. Posisi ketiga ditempati oleh responden Perikanan dan Ilmu Kelautan, dengan persentase 12,9\%. 
Responden terakhir kedua berasal dari Fakultas Ekonomi, dengan persentase sebesar $8,6 \%$, dan responden paling sedikit adalah Sosial dan Politik sebesar 1,4 peserta. Berikut respon yang diberikan oleh responden terkait penerapan e-learning di Universitas Pasifik Morotai;

Tabel 3.Periode Penerapan E-Learning

\begin{tabular}{llcc}
\hline & $\begin{array}{l}\text { Jawaban } \\
\text { Responden }\end{array}$ & Persen & $\begin{array}{l}\text { Kumulatif } \\
\text { Percen }\end{array}$ \\
\hline $\begin{array}{l}\text { Implementasi E- } \\
\text { learning dimasa } \\
\text { pandemi }\end{array}$ & Ya & 10.0 & 10.0 \\
\cline { 2 - 4 } & Tidak & 90.0 & 100.0 \\
\hline $\begin{array}{l}\text { Kesadaran Institusi } \\
\text { pendidikan dalam } \\
\text { pengimplementasikan }\end{array}$ & Ya & 90.0 & 100.0 \\
\cline { 2 - 4 } $\begin{array}{l}\text { E-learning beberapa } \\
\text { tahun terakhir }\end{array}$ & Tidak & 10.0 & 10.0 \\
\hline $\begin{array}{l}\text { Waktu penggunaan e- } \\
\text { learning }\end{array}$ & $\begin{array}{l}\text { Sejak 1 Tahun } \\
\text { terakhir }\end{array}$ & 4.3 & \\
\cline { 2 - 4 } & Belum pernah & 8.6 & 12.9 \\
\cline { 2 - 4 } & $\begin{array}{l}\text { Sejak adanya } \\
\text { pandemic }\end{array}$ & 85.7 & 98.6 \\
& \begin{tabular}{l} 
Covid-19 \\
\cline { 2 - 4 }
\end{tabular} & & \\
\cline { 2 - 4 } & Tidak tahu & 1.4 & 100.0 \\
\hline
\end{tabular}

Tabel 2 mengungkapkan bahwa 90,0\% pendidik dan mahasiswa mulai menggunakan e-learning di masa pandemi, sementara 10,0\% tidak menggunakan e-learning sebagai media pembelajaran. 90,0\% jawaban responden menunjukkan bahwa kurangnya penerapan model e-learning terhadap semua disiplin ilmu. Berdasarkan periode penggunaannya, dapat dianalisis bahwa peserta terbanyak $(85,7 \%)$ percaya baik peserta didik maupun pendidik spontan memanfaatkan e-learning sejak sekolah dan lembaga ditutup dan pemerintah mulai menerapkan sistem lock down. 8,6\% responden menjawab elearning tidak pernah diterapkan di kelas, 4,3\% responden 
mengatakan bahwa e-learning telah diterapkan selama satu tahun yang lalu, dan hanya $1,4 \%$ responden berpendapat bahwa mereka tidak tahu persis kapan dosen menerapkan $e$ learning.

Tabel 4. Persepsi Responden Terhadap Penerapan E-Learning di Masa Penyebaran Covid-19

\begin{tabular}{|c|c|c|c|c|}
\hline & & Percent & $\begin{array}{l}\text { Valid } \\
\text { Percent }\end{array}$ & $\begin{array}{c}\text { Cumulative } \\
\text { Percent }\end{array}$ \\
\hline \multirow[t]{7}{*}{ Valid } & $\begin{array}{l}\text { Kemudahan } \\
\text { dalam } \\
\text { memahami } \\
\text { materi }\end{array}$ & 5.7 & 5.7 & 5.7 \\
\hline & $\begin{array}{l}\text { Sulit dalam } \\
\text { memahami } \\
\text { materi }\end{array}$ & 1.4 & 1.4 & 7.1 \\
\hline & Tidak efektif & 20.0 & 20.0 & 27.1 \\
\hline & $\begin{array}{l}\text { Pengalaman } \\
\text { pembelajaran } \\
\text { yang baru }\end{array}$ & 7.1 & 7.1 & 34.3 \\
\hline & $\begin{array}{l}\text { Fleksibilitas } \\
\text { (waktu dan } \\
\text { tempat) }\end{array}$ & 60.0 & 60.0 & 94.3 \\
\hline & $\begin{array}{l}\text { Efisiensi waktu } \\
\text { dan biaya }\end{array}$ & 5.7 & 5.7 & 100.0 \\
\hline & Total & 100.0 & 100.0 & \\
\hline
\end{tabular}

Data diatas menunjukkan bahwa sebagian besar responden menganggap e-learning memberikan fleksibilitas baik waktu maupun tempat. Dapat dilihat bahwa tingkat persentase item ini lebih tinggi $(60,0 \%)$ dari hal lain, Fleksibilitas terlihat dari kemudahan dosen dan mahasiswa untuk melaksanakan proses belajar mengajar dalam kondisi dan situasi apapun tanpa dipisahkan oleh waktu dan ruang. Dalam situasi mendesak seperti era Covid-19, e-learning 
dianggap sebagai media pembelajaran yang cocok untuk pendidik dan mahasiswa. Selain itu, bukti lain menunjukkan bahwa e-learning mendorong peserta didik mudah menangkap materi dan memberikan efisiensi waktu dan biaya dibandingkan dengan kegiatan belajar tatap muka, dengan masing-masing 5,7\% tanggapan. Disamping itu, 7,1\% responden berpendapat bahwa e-learning dianggap sebagai model pembelajaran baru berbasis teknologi, dimana e-learning dianggap memberikan pengalaman belajar yang baru dan mampu memprovokasi pola pikir siswa. Sebaliknya, beberapa dosen dan mahasiswa menanggapi bahwa selain e-learnng membawa beberapa keuntungan, akan tetapi e-learning dipandang memiliki banyak kelemahan, dapat dibuktikan bahwa 20,0\% responden setuju bahwa e-learning merupakan model pembelajaran yang tidak efektif, dan 1,4\% responden percaya bahwa desain materi e-learning sulit dipahami bagi siswa yang tinggal di daerah terpencil serta bagi siswa yang tinggal di daerah dengan akses internet terbatas.

Tabel 5. Tanggapan Responden Tentang Penerapan E-learning dalam Proses Belajar Mengajar Setelah Berakhirnya Covid-19

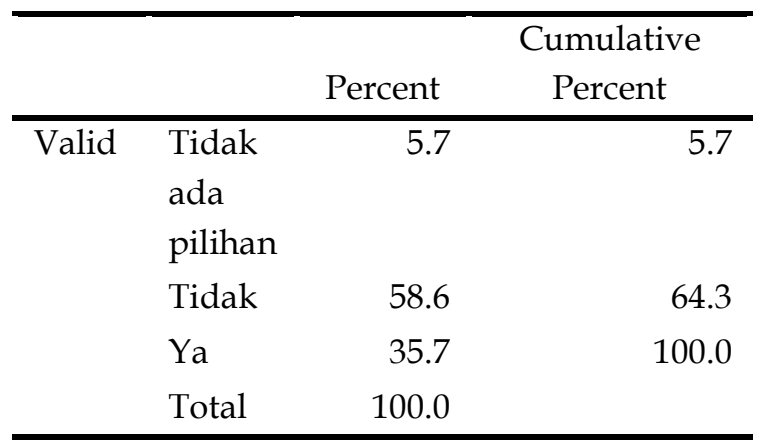

Berdasarkan tabel diatas, dapat dilihat bahwa hanya $35,7 \%$ responden setuju bahwa e-learning harus diadopsi oleh universitas sebagai media pembelajaran meskipun pandemi telah berakhir. Sebaliknya, sebagian besar responden cenderung menolak keberadaan e-learning. 58,6\% pendidik dan 
mahasiswa di Universitas Pasifik Morotai mengklaim bahwa $e$ learning sebaiknya tidak diimplementasikan dalam kelas ketika Covid-19 telah berakhir. Sedangkan 5,7\% responden tidak memberikan pilihan.

\section{Peraturan Model Pembelajaran Online pada Masa Pandemi}

Dalam rangka mencegah meluasnya penularan Covid-19 pada warga sekolah khususnya dan masyarakat luas pada umumya, Kementerian Pendidikan dan Kebudayaan (Kemendikbud) menerbitkan beberapa surat edaran terkait pencegahan dan penanganan Covid-19. Pertama, Surat Edaran Nomor 2 Tahun 2020 tentang Pencegahan dan Penanganan Covid-19 di Lingkungan Kemendikbud. Kedua, Surat Edaran Nomor 3 Tahun 2020 tentang Pencegahan Covid-19 pada Satuan Pendidikan. Ketiga, Surat Edaran Nomor 4 Tahun 2020 tentang Pelaksanaan Kebijakan Pendidikan dalam Masa Darurat Penyebaran Coronavirus Disease (Covid-19) yang antara lain memuat arahan tentang proses belajar dari rumah. Sekolah, di mana setiap hari terjadi aktivitas berkumpul dan berinteraksi antara guru dan siswa dapat menjadi sarana penyebaran Covid-19. Guna melindungi warga sekolah dari paparan Covid-19, berbagai wilayah menetapkan kebijakan belajar dari rumah. Kebijakan tersebut menyasar seluruh jenjang pendidikan mulai dari jenjang prasekolah hingga pendidikan tinggi, baik negeri maupun swasta. Kebijakan belajar di rumah dilaksanakan dengan tetap melibatkan pendidik dan peserta didik melalui Pembelajaran Jarak Jauh (PJJ) (Arifah, 2020).

Pada peringatan Hari Pendidikan Nasional (Hardiknas) 2 Mei 2020, Kementerian Pendidikan dan Kebudayaan (Kemendikbud) mengaskan strategi penerapan kegiatan belajar di masa pandemi Covid-19 ini. Sebagai upaya untuk menegakkan Kegiatan Belajar Bengajar (KBM) di tengah Pandemi Covid-19, Kemendikbud telah mengatur kebijakan melalui Surat Edaran Nomor 4 tahun 2020 Kementerian Pendidikan yang memuat empat hal tersebut. Ada empat 
pokok utama strategi yang diusung Kemendikbud (Republika.co.id, 26 Maret 2020).

1. Pembelajaran secara daring, baik secara interaktif maupun non interaktif. Hal ini perlu dilakukan meskipun tidak semua anak-anak dapat melakukan itu karena faktor infrastruktur.

2. Tenaga pengajar atau guru harus memberikan pendidikan kepada anak-anak tentang kecakapan hidup, yakni pendidikan yang bersifat kontekstual sesuai kondisi rumah masing-masing, terutama pengertian tentang Covid-19, mengenai karakteristik, cara menghindarinya dan bagaimana cara agar seseorang tidak terjangkit.

3. Pembelajaran di rumah harus disesuaikan dengan minat dan kondisi masing-masing anak.

4. Bagi para tenaga pengajar atau guru, tugas-tugas yang diberikan kepada siswa tidak harus dinilai seperti biasanya di sekolah, akan tetapi penilaian lebih banyak kualitatif yang sifatnya memberi motivasi kepada anak-anak.

Terdapat beberapa kelompok pembelajaran yang diselenggarakan di sekolah selama pandemi Covid-19, yakni sekolah yang menyelenggarakan pembelajaran jarak jauh secara penuh dan memanfaatkan berbagai platform pendidikan daring, sekolah yang masih menerapkan semi daring, yang mana tugas dikirim melalui aplikasi pesan dan tidak ada interaksi langsung, dan yang tidak memiliki akses internet, listrik, maupun televise (Republika.co.id, 26 Maret 2020).

Zhou et al (2020) melalui sebuah penelitian yang dilakukan di China tentang penerapan e-learning guna mencegah peyebaran pandemi, Zhou menjelaskan bahwa sejak tanggal 6 Maret 2020, Kemendikbud mengeluarkan surat keputusan terkait dengan system pembelajaran "School's Out, But Class's On", yang artinya sekolah diliburkan akan tetapi pembelajaran tetap berlangsung secara online. Pemerintah secara sigap mempromosikan model pembelajaran "School's Out, But Class's On" serta langkah-langkah dan peraturan 
terkait model pembelajaran tersebut, adapun aturan yang ditetapkan oleh Kemendikbud tentang model pembelajaran School's Out, But Class's On meliputi;

1. Memanfaatkan sumber daya televisi dan jaringan secara keseluruhan untuk mencapai manfaat, berbagi sumber daya, dan cakupan yang komprehensif, terutama untuk memenuhi kebutuhan belajar siswa di daerah pedesaan terpencil ketika jaringan kurang memadai atau sinyal lemah.

2. Mengkoordinasikan pembelajaran kurikulum dan pendidikan khusus tentang memerangi "epidemi", dan memperkuat bimbingan pendidikan patriotisme. Fokus pada pendidikan lanjutan dan pengetahuan pencegahan epidemi, pendidikan kehidupan, pendidikan keselamatan publik, dan pendidikan kesehatan mental sebagai konten pembelajaran penting. Membimbing siswa untuk melakukan hal-hal yang benar, menjaga hubungan antara manusia, masyarakat dan alam, untuk menghormati dunia objektif, bertindak secara ilmiah dan rasional, dan untuk menumbuhkan patriotisme, cinta terhadap sesama, dan sosialisme.

3. Mengkoordinasikan karakteristik pembelajaran online dan kebutuhan aktual siswa, mencegah metode pengajaran kelas normal, durasi, dan pengaturan pengajaran dan memperkuat bimbingan belajar baik pada nilai dan disiplin ilmu yang berbeda.

4. Memanfaatkan sumber daya lokal dan platform nasional secara keseluruhan, serta memandu lokal dan sekolah untuk memanfaatkan platform jaringan sekolah dasar dan menengah dengan baik dan sumber daya pembelajaran yang disiarkan melalui saluran televisi 4 yakni kelas Pendidikan China.

5. Mengkoordinasikan peran guru pada semua guru sebagai tulang punggung pendidikan, mengatur guru dalam perekaman pembelajaran, penyediaan sumber daya dan bimbingan pengajaran online, dan mengatur semua guru untuk berpartisipasi dalam bimbingan pembelajaran online, 
menjawab pertanyaan, dan komunikasi di rumah-sekolah dengan berbagai cara.

6. Menggabungkan perencanaan secara keseluruhan dan promosi aktif melalui penerapan sesuai standar, memperhatikan perilaku pengajaran online yang tepat waktu dan terstandar. Dalam hal ini melarang keras guru untuk melakukan perekaman proses pembelajaran secara tradisional. Siswa tidak boleh dipaksa untuk "Clock In" dan memuat video pembelajaran di Internet setiap hari. Meminta orang tua wali murid untuk menghindari pembelian peralatan rumah tangga untuk sementara waktu karena tugas cetak atau bahan belajar, yang akan meningkatkan beban keuangan keluarga siswa (Departemen Pendidikan Republik Rakyat Tiongkok, 2020).

Departemen Pendidikan Provinsi Zhejiang telah membuat peraturan yang jelas untuk pengajaran online guna mencegah dan mengendalikan situasi terhadap infeksi Epidemi Pneumonia COVID-19, yakni;

1. Patuhi pendidikan lima inti (moralitas, kecerdasan, olahraga, estetika, dan tenaga kerja) dan pengembangan yang komprehensif.

2. Dorong sumber daya kurikulum, buku teks elektronik, peninjauan, penyelesaian tugas (PR) secara manual, menjalankan tugas online secara tepat waktu.

3. Pengajaran online diselenggarakan oleh kelas sebagai unit dan interaksi dua arah. Hal ini terutama didasarkan pada rekaman dan penyiaran dapat mengadopsi bentuk "rekaman + online $Q \mathcal{E} A$ ". Les setelah sekolah dapat berbentuk on-demand atau online $Q \mathcal{E} A$.

4. Waktu mengajar untuk setiap pelajaran adalah sekitar 20 menit di sekolah dasar dan sekitar 30 menit di sekolah menengah, disamping itu guru memyediakan waktu untuk melakukan pratinjau dan latihan di setiap kelas online. 
5. Berbagai bentuk pekerjaan rumah harus diatur untuk pengajaran online, dan konten siswa harus diperiksa dan dievaluasi secara tepat waktu.

Selain itu, pada 29 Februari 2020, Biro Pendidikan Guangzhou mengajukan pedoman kerja untuk pembelajaran online di sekolah dasar dan menengah, adapun pedoman kerja tersebut meliputi;

1. Patuhi pendidikan lima inti (moralitas, kecerdasan, olahraga, estetika, dan tenaga kerja) pada saat yang sama dan merumuskan program pendidikan online.

2. Secara ilmiah memahami kemajuan dan mengatur pekerjaan dan beristirahat secara wajar.

3. Menggabungkan kelas online dan offline untuk menghindari peningkatan beban siswa.

4. Mendirikan "ruang kelas televisi" untuk melakukan pekerjaan yang baik dalam mendukung kota.

5. Secara akurat menganalisis situasi akademik, dan memastikan koneksi kembali ke sekolah.

6. Memperkuat panduan inti dan menerapkan pendidikan online di sekolah menengah kejuruan.

7. Mengambil langkah-langkah untuk memastikan kelancaran kemajuan pembelajaran online. 


\section{BAB IV \\ TANTANGAN PEMBELAJARAN E-LEARNING DIMASA PANDEMI}

\section{A. Proses Belajar Dari Rumah}

Secara global, berdasarkan data UNESCO tanggal 19 Maret 2020, 112 negara telah menerapkan kebijakan belajar dari rumah, antara lain Malaysia, Thailand, Jerman, Austria, Meksiko, Afrika Selatan, Yaman, dan Zambia. Dari 112 negara tersebut, 101 negara menerapkan kebijakan belajar dari rumah secara nasional. Sementara 11 negara lainnya, termasuk Indonesia, menerapkan belajar di rumah di wilayah-wilayah tertentu (bebas.kompas.id, 31 Maret 2020).

Di Indonesia, kebijakan belajar dari rumah telah dilaksanakan oleh sekitar 28,6 juta siswa dari jenjang SD sampai dengan SMA/SMK di berbagai provinsi. Per 18 Maret 2020, sebanyak 276 perguruan tinggi negeri dan swasta di Indonesia telah menerapkan kuliah daring (bebas. kompas.id, 31 Maret 2020). Di beberapa daerah proses pembelajaran dari rumah telah berlangsung sejak 16 Maret 2020 dan diperpanjang dengan mempertimbangkan situasi di masing-masing daerah. Dari sisi sumber daya manusia, pendidik maupun peserta didik ada yang memang sudah siap. Tetapi banyak pula yang terpaksa harus siap menghadapi pembelajaran yang biasanya dilaksanakan secara tatap muka berubah menjadi sistem belajar jarak jauh secara daring. Bagi sekolah yang telah terbiasa menggunakan perangkat teknologi dalam kegiatan belajar mengajar tentu tidak banyak menghadapi kendala, Tetapi tidak demikian bagi sekolah yang belum pernah melaksanakan PJJ sebelumnya, terutama di daerah dengan fasilitas yang terbatas baik sisi peranti maupun jaringan (Arifa, 2020)..

Lembaga pendidikan misalnya Universitas Terbuka (UT), menggunakan e-learning sebagai sarana pendidikan di mana sudah siap dari sisi sumber daya manusia, memiliki kurikulum yang matang, serta dilengkapi fasilitas untuk mengakses sumber belajar dan sarana komunikasi yang efektif 
antara mahasiswa dan tutor. Namun, masih banyak lembaga pendidikan terutama yang berada di daerah tertinggal, jauh dari siap akibat berbagai keterbatasan. Sebagian besar proses PJJ saat ini masih memanfaatkan fasilitas grup Whatsapp dalam perangkat smart phone. Guru maupun dosen memberikan tugas kepada para peserta didik melalui grup Whatsapp, baik melalui grup orang tua siswa maupun grup kelas masingmasing. Waktu belajar sesuai dengan jadwal mata pelajaran harian. Materi belajar dipelajari secara mandiri kemudian dilanjutkan dengan mengerjakan tugas harian. Diskusi terkait materi yang dipelajari dilakukan melalui grup tersebut. Untuk mengadakan tatap muka virtual dapat menggunakan aplikasi Google Classroom, Zoom, atau media lainnya. Dengan fitur ini, guru bisa memantau kehadiran dan keaktifan peserta didik (Arifa, 2020).

\section{B. Tantangan Proses Belajar Dari Rumah}

Menurut Arifa (2020) Proses pembelajaran dari rumah melalui PJJ idealnya tetap dapat mengakomodasi kebutuhan belajar siswa untuk mengembangkan bakat dan minat sesuai dengan jenjang pendidikannya. Untuk mewujudkan hal tersebut diperlukan kesiapan pendidik, kurikulum yang sesuai, ketersediaan sumber belajar, serta dukungan peranti dan jaringan yang stabil sehingga komunikasi antar peserta didik dan pendidik dapat efektif. Kondisi PJJ saat ini belum dapat disebut ideal sebab masih terdapat berbagai hambatan yang dihadapi. Hambatan tersebut sekaligus menjadi tantangan dalam pelaksanaan PJJ mengingat pelaksanaan PJJ merupakan keharusan agar kegiatan pendidikan tetap dapat terselenggara di tengah darurat pandemi Covid-19 yang terjadi saat ini. Hambatan yang dihadapi dalam pelaksanaan PJJ antara lain berkaitan dengan kesiapan sumber daya manusia, kurang jelasnya arahan pemerintah daerah, belum adanya kurikulum yang tepat, dan keterbatasan sarana dan prasarana, khususnya dukungan teknologi dan jaringan internet. Kesiapan sumber daya manusia meliputi pendidik (guru dan dosen), peserta 
didik, dan dukungan orang tua merupakan bagian terpenting dalam pelaksanaan PJJ. Banyak keluhan baik dari pendidik, peserta didik, maupun orang tua terkait pelaksanaan belajar dari rumah. Banyak pendidik yang mengeluhkan terbatasnya ketersediaan sarana teknologi, kemampuan pengoperasian maupun keterbatasan jaringan internet di beberapa daerah. Di sisi lain, Sejak 16 Maret sampai 9 April 2020, Komisi Perlindungan Anak Indonesia (KPAI) menerima sekitar 213 pengaduan PJJ baik dari orang tua maupun siswa (Kompas, 14 April 2020). Pengaduan tersebut berkaitan dengan: pertama, penugasan yang terlalu berat dengan waktu yang singkat. Kedua, banyak tugas merangkum dan menyalin dari buku. Ketiga, jam belajar masih kaku. Keempat, keterbatasan kuota untuk mengkuti pembelajaran daring. Dan kelima, sebagian siswa tidak mempunyai gawai pribadi sehingga kesulitan dalam mengikuti ujian daring. Keluhan juga dialami oleh mahasiswa dalam memahami materi perkuliahan. Berdasarkan survei Pusat Inovasi dan Kajian Akademik UGM terhadap 3.353 mahasiswa yang mengikuti pembelajaran daring dalam masa darurat Covid-19, sebanyak 66,9\% mahasiswa merasa memahami materi perkuliahan dengan baik, sedangkan sisanya mengaku kurang atau sangat kurang memahami dengan baik (vice. com, 30 Maret 2010). Kurangnya pemahaman mahasiswa terhadap materi perkuliahan salah satunya disebabkan oleh kurang siapnya dosen dalam mengelola PJJ sehingga berpengaruh terhadap capaian pembelajaran. Plt. Kepala Pusat Data dan Teknologi Informasi Kemendikbud, Gogot Suharwoto mengatakan dinas pendidikan mempunyai andil kuat terkait pembelajaran yang belum maksimal. Menurutnya, arahan dari dinas pendidikan terhadap sekolah terkait pembelajaran di rumah belum jelas (cnnindonesia.com, 31 Maret 2020). Surat edaran kepala dinas pendidikan dinilai masih kurang detil dan spesifik menjelaskan mengenai tugas guru, orang tua, dan siswa sehingga berpengaruh terhadap kesiapan pelaksanaan pembelajaran. Dari sisi akses, tantangan bagi pemerintah adalah ketika PJJ dilaksanakan di wilayah yang aksesibilitas, 
infrastruktur, dan literasi digitalnya masih rendah. Berdasarkan hasil survei Nasional Penetrasi Pengguna Internet 2018 APJII, sebaran data menunjukkan bahwa lebih dari separuh pengguna internet di indonesia berada di wilayah Jawa $(55,7 \%)$, diikuti Sumatera (21,6\%), Sulawesi-MalukuPapua (10,9\%), Kalimantan $(6,6 \%)$, serta Bali dan Nusa Tenggara sebesar 5,2\% (bebas.kompas.id, 30 Maret 2020). Salah satu kesulitan yang dihadapi dalam proses belajar dari rumah adalah keterbatasan internet baik dari ketersediaan jaringan maupun kuota untuk mengakses pembelajaran daring.

\section{Tantangan E-Learning yang di Hadapi Universitas di Seluruh Dunia Akibat Wabah Covid-19}

Sahu (2020) mengulas beberapa tantangan yang dihadapi universitas di seluruh dunia akibat wabah COVID-19:

1. Beralih dari Tatap Muka ke Kelas Online

Di seluruh dunia, banyak guru dan siswa sangat antusias dengan beralih ke mode pembelajaran online. Universitas telah mulai mempersiapkan rencana pelajaran untuk memberikan pengajaran online kepada siswa mereka. Pengajaran online bukanlah mode pembelajaran baru di universitas mana pun. Banyak Universitas mendapatkan pelatihan untuk menggunakan platform pembelajaran online baik sebagai satu-satunya mode pembelajaran atau sebagai model pembelajaran tambahan selain mengajar tatap muka (Anonima , 2020) Namun demikian, selalu ada kemungkinan bahwa beberapa Universitas yang tidak menerapkan pembelajaran berbasis teknologi tidak akan mampu mengatasi mode ini (Anonima, 2020). Transisi ke mode online telah menimbulkan pertanyaan bagi fakultas tentang kemampuan mereka untuk menangani teknologi yang ada (Anonimb ${ }^{b}$ 2020) Selain itu, komputer dan peralatan IT di rumah kini diminati oleh orang tua, anak-anak, dan kerabat lainnya yang harus bekerja dari rumah. Dengan demikian, bekerja di rumah akan menjadi tugas yang sulit bagi perguruan tinggi Juga, banyak perguruan tinggi tidak 
memiliki infrastruktur atau sumber daya yang cukup untuk memfasilitasi pengajaran online dengan efek langsung (Anonimc, 2020). Bagaimana dengan siswa yang tidak memiliki akses ke laptop dan fasilitas internet di rumah? Apakah mungkin untuk melakukan praktikum di laboratorium secara online, serta mengajar musik dan seni secara online? Apa yang akan terjadi pada siswa yang proses belajar- mengajarnya tidak dapat diajarkan secara online? Kualitas pendidikan online adalah masalah penting yang membutuhkan perhatian yang tepat (Sahu, 2020).

2. Penilaian dan Evaluasi

Transisi dari pengajaran tatap muka ke pembelajaran online memiliki dampak serius pada penilaian dan evaluasi. Meskipun teknologi telah digunakan sebelumnya untuk mendukung pengajaran dan pembelajaran, aspek penilaian sering kurang berkembang (Timmis $S$ et al., 2016). Menerapkan penilaian secara online pada materi-materi yang dirancang untuk pembelajaran tatap muka adalah tugas yang menantang. Mahasiswa, serta perguruan tinggi, tidak yakin tentang prosedur untuk mengelola tugas, proyek, dan penilaian (Kearns, 2012; Raaheim et al., 2019). Anggota perguruan tinggi harus mengubah jenis penilaian agar sesuai dengan mode online. Sulit untuk memantau bagaimana mereka mengambil secara online dan untuk memastikan bahwa mahasiswa tidak curang selama tes online (Watson \& Sottile, 2010). Tes laboratorium, praktis, dan tes kinerja tidak mungkin dilakukan secara online. Selain itu, siswa yang tidak memiliki fasilitas Internet akan menderita kerugian yang sangat besar saat berpartisipasi dalam proses evaluasi, yang akan mempengaruhi rata-rata poin nilai (IPK) mereka (Alruwais et al., 2018).

Pelaksanaan E-assesment di perguruan tinggi memungkinkan mengalami beberapa tantangan. Studi yang berbeda dilakukan oleh (Alruwais et al., 2018) telah mengkaji tentang tantangan ini dan solusi yang disarankan: 
a. Pelajar yang tidak berpengalaman dengan komputer atau dengan proses penilaian (Osuji, 2012; Donovan et al., 2007). Mahasiswa memerlukan pelatihan diawal untuk menjadi akrab dengan E-assesment (Osuji, 2012).

b. Aksesibilitas komputer dan internet (Crews \& Curtis, 2011; Osuji, 2012). Sebagai solusi untuk masalah ini, universitas harus menyediakan laboratorium dengan peralatan lengkap dan akses internet bagi mahasiswa.

c. Pembangunan infrastruktur teknologi yang buruk, khususnya negara-negara miskin untuk pelajar Nigeria (Osuji, 2012). Pemerintah harus menyediakan peralatan lengkap untuk mengatur sistem penilaian elektronik.

d. Ridgway et al. (2004) membahas kesulitan dalam memberikan penilaian dan mengoreksi pertanyaan dengan tanggapan terbuka siswa. Ridgway menggambarkan beberapa solusi. Salah satu keberhasilan adalah membandingkan korelasi antara komputer dan penilaian manusia, dan korelasi antara skor dua penilaian manusia. Selain itu, komputer akan menyesuaikan dengan pertanyaan apabila jawaban terdefinisikan dengan baik seperti pertanyaan Jawaban singkat, Ridgway et al (2004). (Mitchell et al., 2003) memaparkan contoh di Dundee Medical School, dimana tanggapan ujian sekolah terdefinisikan dengan baik untuk masing-masing pertanyaan dalam ujian dengan menggunakan korelasi komputer. Mereka menemukan bahwa waktu penilaian manusia menurun secara signifikan dan tenaga kependidikan melaporkan bahwa jenis kualitas pertanyaan meningkat serta dengan meredaksi kembali pertanyaan dapat menentukan kekeliruan yang dilakukan oleh siswa.

e. Menilai suatu kerja kelompok adalah pekerjaan yang sulit. Perlu memantau keterampilan komunikasi, mengevaluasi kelompok bekerja, menilai setiap anggota dan seluruh kelompok, serta memberikan umpan balik. Sulit untuk menggunakan komputer dalam tugas ini. 
Namun, SPARK (Self Peer Assessment Resource Kit) adalah proyek akses akademik terbuka yang dirancang untuk mendukung evaluasi kerja kelompok yang efektif, yang telah digunakan di banyak universitas dalam konteks yang berbeda (Ridgway et al., 2004).

f. Beberapa guru tidak terbiasa dengan teknologi, atau sebagian besar mereka menggunakan E-assessment untuk pertama kalinya. Oleh karena itu, guru memerlukan pelatihan agar lebih percaya diri dalam menggunakan system E-assessment (Ridgway et al., 2004; Jordan \& Mitchell, 2009)

Selain itu, studi lain yang dilakukan oleh Kearns (2012) dengan mengkategorisasikan tiga tema luas yang muncul dari tantangan penilaian berbasis online:

1. Dampak jarak fisik antara instruktur dan siswa;

2. Adaptasi yang dihasilkan dari kebutuhan menggunakan teknologi untuk berkomunikasi dengan siswa;

3. Beban kerja dan manajemen waktu.

Tiga tema tantangan yang disebutkan di atas dapat dianggap sebagai kondisi yang membatasi secara imperatif. Dalam pembelajaran online, siswa dan instruktur tidak bertemu secara teratur; pada kenyataannya, dalam kebanyakan kasus, mereka tidak saling melihat satu sama lain. Seperti yang dikatakan salah satu instruktur, "peluang insidental" untuk komunikasi yang ada dalam pengaturan kelas F2F tidak terjadi di kelas online. Karena itu, beberapa instruktur mengulas tentang perhatian khusus yang dirasakan pada saat pembelajaran online diterapkan. Beberapa menyatakan keprihatinan terhadap pernyataan instruktur yang mampu secara akurat menilai kemajuan siswa mereka sepanjang semester. Yang lain mengomentari kesulitan dalam mengajar secara kompleks, pemecahan masalah berbasis metode multistep untuk memberikan jarak kepada siswa(Kearns, 2012). 
Penelitian lain yang dilakukan oleh Watson \& Sottile (2010), penelitian ini mengkaji tentang perbandingan kecurangan melalui tes online dan tes secara tatap muka. Watson et al, mengungkapkan bahwa tingkat ketidak-jujuran akademik yang lebih tinggi dalam pembelajaran tradisional atau face-to-face. Studi menunjukkan bahwa kecurangan dalam kelas online tidak lebih merajalela daripada kecurangan di kelas tatap muka atau kelas tradisional. Meskipun demikian, data menunjukkan bahwa siswa secara signifikan lebih mungkin untuk mendapatkan jawaban dari orang lain selama tes online atau kuis. Kemampuan untuk menerima jawaban tanpa pemantauan seorang profesor, menyajikan masalah untuk kuliah berbasis standar atau pembelajaran yang di gerakan oleh tes. Pengembang pembelajaran harus mengambil tindakan pencegahan ekstra sehubungan dengan tes online atau kuis, baik melalui proctor pengujian, mengubah jenis penilaian, atau menurunkan nilai penilaian dalam kaitannya dengan tugas pembelajaran lainnya. Dalam contoh proctors tes, ada beberapa contoh di mana fakultas mengharuskan siswa untuk berada di kampus untuk mengikuti ujian secara pribadi pada tanggal dan waktu yang ditetapkan, untuk memastikan orang yang mengikuti tes adalah siswa yang terdaftar di kelas.

1. Mahasiswa Internasional

(Sahu, 2020) Terdapat banyak pelajar internasional yang belajar di universitas yang melakukan perjalanan ke rumah mereka, hal ini tentunya sangat tidak memungkinkan dalam situasi kritis seperti ini. Sementara universitas menutup kampus. Penting untuk mempertimbangkan bahwa sebagian besar pelajar tidak memiliki fasilitas akomodasi lain di luar kampus tersebut (Anonim ${ }^{d}$, 2020) Ini telah menjadi tantangan besar bagi administrator untuk memastikan makanan, akomodasi, dan layanan keselamatan bagi pelajar atau mahasiswa nonnasional. Pelajar atau mahasiswa juga membutuhkan saran yang tepat untuk melindungi diri dari kontak orang ke orang dan hidup dalam isolasi diri sampai situasi menjadi 
normal. Perpanjangan tinggal karena keterlambatan pemeriksaan dapat menyebabkan masalah moneter. Mereka yang berhasil pulang khawatir bahwa studinya akan terganggu. Di rumah, banyak mahasiswa mungkin tidak memiliki fasilitas yang memadai seperti buku, komputer, dan koneksi Internet berkecepatan tinggi. Sekali lagi, gangguan akibat COVID-19 dapat mempengaruhi penerimaan siswa internasional untuk sesi akademik mendatang (Anonime ${ }^{e}$ 2020).

2. Pembatasan Perjalanan

Wabah COVID-19 telah menciptakan kekacauan di seluruh dunia bagi maskapai penerbangan. Negara-negara di seluruh dunia menutup perbatasan internasional untuk mengurangi wabah. Administrasi universitas menyarankan anggota staf mereka untuk menunda partisipasi dalam setiap acara yang mengharuskan mereka untuk melakukan perjalanan ke luar negeri sampai kembali ke situasi dan kondisi normal. Jelas bahwa banyak anggota staf telah membayar biaya pendaftaran konferensi dan tiket pesawat dari studi dan perjalanan atau dana universitas lainnya. Ini menimbulkan keadaan kebingungan di antara staf saat berurusan dengan situasi seperti itu. Universitas di seluruh dunia meminta siswa internasional untuk tidak bepergian ke luar negeri dan melanjutkan studi mereka dari hostel. Pelajar yang bepergian ke luar negeri menempatkan diri mereka pada risiko terinfeksi (Sahu, 2020).

3. Kesehatan Mental

Wabah COVID-19 telah mengganggu kehidupan khalayak ramai di seluruh dunia. Peningkatan secara cepat kasus terinfeksi di seluruh dunia telah menciptakan rasa ketidakpastian dan kecemasan tentang apa yang akan terjadi. Hal ini juga menyebabkan tingkat stres yang luar biasa di antara persaudaraan universitas, termasuk siswa. Stres ini dapat menyebabkan efek yang tidak 
menguntungkan pada pembelajaran dan kesehatan psikologis siswa. Siswa internasional yang tinggal jauh dari rumah tidak hanya khawatir tentang kesehatan, keselamatan, dan pendidikan mereka tetapi mereka juga memiliki sejumlah besar kekhawatiran untuk kesejahteraan keluarga mereka. Pertanyaan muncul: Apakah universitas mengambil langkah-langkah proaktif untuk mendukung kesehatan mental dan kesejahteraan siswa? Apakah universitas memiliki konselor yang terlatih secara profesional yang dapat memahami siswa seperti itu?. Siswa yang berhasil pulang khawatir tidak dapat kembali ke lembaga masing-masing untuk studi lebih lanjut(Sahu, 2020).

\section{Tantangan Proses Pembelajaran Daring di Sekolah Dan Perguruan Tinggi}

Tantangan mewarnai proses pembelajaran online dikarenakan jaringan yang lamban, sehingga informasi ataupun materi yang disampaikan memerlukan waktu yang cukup lama untuk di terima oleh orang tua, atau pun sebaliknya. Hal ini juga faktor dari jarak dan keterbatasan jaringan yang berada di lingkungan tempat tinggal murid. Beberapa siswa menyatakan bahwa dalam pembelajaran, materi yang disampaikan terkadang tidak sejalan dengan apa yang ditargetkan guru. Dalam pengumpulan tugas pun, guru kewalahan memberikan jangka waktu karena berbagai alasan yang diberikan oleh murid. Dilihat dari salah satu faktor yang mempengaruhi, yakni kuota internet menjadi kendala utama dalam proses pembelajaran online, karena kuota internet mengakomodasi lancarnya proses pembelajaran online. Tantangan bagi guru dalam proses pembelajaran online ialah penugasan yang diberikan kepada murid tidak sepenuhnya murid yang melakukan, adanya campur tangan orang tua dalam proses penugasan. Namun, ada juga orang tua yang tidak dapat membersamai dirumah, sehingga tidak ada yang dapat membantu dalam mengakomodasi sarana pembelajaran 
murid. "Murid kadang dalam mengerjakan tugas, tidak sepenuhnya ia yang melakukan ataupun ada juga orang tua tidak ada dirumah, sehingga tidak ada yang dapat membantu dalam mengakomodasi sarana pembelajaran murid. lebih mengedepankan keterbatasan media saat pelaksanaan pembelajaran online dilaksanakan merupakan salah satu tantangan tersendiri. Faktanya masih ada murid dan orang tua yang belum melek teknologi. Sebuah penelitian menyatakan bahwa aktivitas dalam pengajaran tidak mudah dalam memfasilitasi (Moorhouse, 2020). Namun, gabungan antara keselarasan dan mode ketidakselarasan dari instruksi dilihat menjadi sebuah cara dalam mendukung pembelajaran dalam teknologi ketika face-to-face tidak menjadi pilihan. Pembelajaran daring memberikan manfaat yang luas, yakni dapat menjangkau ke seluruh wilayah, namun dalam temuan lainnya menyatakan bahwa ada beberapa kendala yang dihadapi di beberapa wilayah (Satrianingrum \& Prasetyo, 2020).

Satrianingrum \& Prasetyo (2020) Indonesia, yang mana penyebaran dan keterjangkauan layanan internet yang menjadi lamban sewaktu-waktu. Juga jika penggunaan platform banyak dalam satu grup, maka akan menyebabkan overload (Bao, 2020; Pramudibyanto, Khasanah, \& Widuroyekti, 2020). Serta tantangan yang dirasakan oleh dalam pelaksanaan pembelajaran online ialah belum adanya kurikulum yang tepat dalam situasi seperti saat ini, ketersediaan sarana dan prasarana yang belum memadai, seperti teknologi dan jaringan internet serta kesiapan sumber daya manusia itu sendiri, salah satunya pendidik. Sehingga dengan kondisi yang sedang dihadapi mengahruskan tenaga pendidik dan guru untuk lebih adaptif serta inovatif (Ahmed, Shehata, \& Hasanien, 2020; Arifa, 2020). Apalagi ditambah dengan ditribusi guru yang tidak merata (Mahbub et al., 2020). Guru terpusat pada perkotaan, sedangkan pada pedesaan lebih banyak kendala yang dihadapi. Dengan pelaksanaan pembelajaran online ini tetaplah menjadikan guru dan murid tetap dekat walaupun melalui komunikasi instant messaging platform (IMP). Hal 
terpenting tantangan tersebut tetap di evaluasi agar mendapatkan pembelajaran yang maksimal dan menciptakan keterampilan belajar yang mandiri dalam pandemik ini (Herliandry, Nurhasanah., Suban,\& Kuswanto, 2020).

Sadikin \& Hamidah (2020) Sebuah penelitian lain yang menggambarkan pembelajaran online yang diselenggarakan di Prodi Pendidikan Biologi FKIP Universitas Jambi sebagai upaya dalam menekan mata rantai penyebaran Covid-19 di lingkungan perguruan tinggi mengungkapkan bahwa tantangan pembelajaran online adalah ketersediaan layanan internet. Sebagian mahasiswa mengakses internet menggunakan layanan selular, dan sebagian kecil menggunakan layanan wi-fi. Ketika kebijakan pembelajaran online diterapkan di Universitas Jambi, mahasiswa kembali ke kampung halamannya. Mereka mengalami kesulitan sinyal selular ketika di daerah masing-masing, jikapun ada sinyal yang didapatkan sangat lemah. Hal ini menjadi tantangan tersendiri dalam penerapan pembelajaran online di Universitas Jambi. Pembelajaran online memiliki kelemahan ketika layanan internet lemah, dan intruksi dosen yang kurang dipahami oleh mahasiswa (Astuti, P., \& Febrian, F.,2019). Tantang lain yang dihadapi adalah kendala dalam pembiayaan pembelajaran online. Mahasiswa mengungkapkan bahwa untuk mengikuti pembelajaran online, mereka harus mengeluarkan biaya cukup mahal untuk membeli kuota data internet. Menurut mereka, pembelajaran dalam bentuk konferensi video telah menghabiskan banyak kuota data, sementara diskusi online melalui applikasi pesan instan tidak membutuhkan banyak kuota. Rata-rata mahasiswa menghabiskan dana Rp. 100.000 sampai Rp. 200.000 per minggu, tergantung provider seluler yang digunakan. Penggunaan pembelajaran daring menggunakan konferensi video membutuhkan biaya yang cukup mahal (Naserly, M. K., 2020).

Walaupun penggunaan gawai dapat mendukung pembelajaran online, tetapi ada dampak negatif yang perlu mendapat perhatian dan diantisipasi yaitu penggunaan gawai 
yang berlebihan. Mereka mengakui bahwa selain untuk pembelajaran, mahasiswa juga menggunakan gawai untuk media sosial dan menonton youtube. Media sosial telah memasuki ranah kehidupan golongan dewasa awal (Lau, 2017). Mahasiswa mengakses media sosial dalam rangka ekspresi diri, membangun jejaring pertemanan dan opini (Kim, Wang, \& Oh, 2016). Sangat disayangkan, banyak orang kecanduan gawai akibat menggunakannya secara berlebihan (Waslh, White \& Young, 2007). Perlu dikhawatirkan masuknya informasi yang menyesatkan dan tidak perhatian selama belajar akibat bermain media sosial (Siddiqui \& Singh, 2016). Selain itu, peserta didik yang kecanduan gawai memiliki masalah akademik dan sosial (Kwon et al., 2013). Peserta didik yang memiliki kecanduan gadget memiliki masalah emosional dan perilaku (Asif, A. R., \& Rahmadi, F. A., 2017). 


\section{BAB V \\ PERSEPSI GURU TERHADAP IMPLEMENTASI E- LEARNING DI MASA COVID-19}

\section{A. Dampak Pandemik terhadap Siswa}

Satrianingrum \& Prasetyo (2020) berdasarkan penelitian yang telah dilakukan menyatakan bahwa ada sebagian dari orang tua murid tidak menggunakan perangkat-perangkat yang memadai. Dalam pelaksanaan pembelajaran secara online yang dilakukan di rumah, salah satu keterbatasan dalam pelaksanaan ini ialah sarana dan prasarana yang mendukung, seperti laptop, komputer, handphone, kouta internet dan lain sebagainya. Sarana prasarana menjadi begitu penting dalam mengakomodasi pelaksanaan pembelajaran bagi murid. Pelaksanaan pembelajaran online dirasa belum optimal dalam penyampaian materi pembelajaran kepada murid, karena biasa belajar di kelas secara face-to-face, sekarang penyampaian materi melalui sebuah wadah. Sehingga guru merasa bahwa pembelajaran menjadi tidak bermakna bagi murid. Salah satu faktornya ialah pembelajaran tidak dilakukan dengan tatap muka secara langsung, maka proses pembelajaran lebih difokuskan dalam bentuk penugasan kepada murid. Ditambah dengan kurangnya minat murid, karena melakukan pembelajaran melalui sebuah grup di aplikasi yang dominan berisi teks. Hal tersebut hanya menstimulasi daya visual anak."Apalagi setelah melakukan pembelajaran secara online, anak-anak lebih banyak bermain handphone setelah pembelajaran" ungkap orang tua yang menceritakan kepada peneliti. Gaya belajar murid dalam pembelajaran secara online cenderung lebih visual dan baca tulis yang kuat (Drago,\& Wagner, 2004). Banyaknya platform yang mendukung secara gratis, seperti Google Classroom, Whatsapp, Quipper dan lain sebagainya (Abidah, Hidayaatullaah, Simamora, Fehabutar,\& Mutakinati, 2020) yang dapat mengirimkan pesan teks, gambar, video dan file lain (Kusuma, 2020) namun penggunaan platform tersebut belum efektif, karena keterbatasan sarana prasarana di 
sebagian murid kurang memadai. Pelaksanaan pembelajaran secara online terkesan tidak rata dan cenderung teacher-centered. Ditambah lagi, jika melakukan sebuah diskusi, ada yang menjadi silence reader dan respon dari murid pun sedikit lebih pendek (Moorhouse, 2020). Penelitian ini didukung dalam temuannya 1 dari 58 siswa sangat paham mengenai pembelajaran secara online, 23 dari 58 siswa mengerti, dan selebihnya mereka menjawab kadang mengerti (Anhusadar, 2020). Proses interaksi antara pengontrolan dan lingkungan kelas, sangat berpengaruh kepada murid, seperti misalnya semangat siswa yang terjadi saat di lingkungan ruangan kelas (Hershkovitz, Elhija, \&Zedan, 2019), namun akan berbeda jika melakukan pembelajaraan saat dirumah. Sehingga tidak menimbulkan motivasi yang tinggi. Selain itu, sarana prasarana yang menjadi fasilitas utama dalam lancarnya pelaksanaan pembelajaran online ini. Selain itu, setianingrum menambahkan bahwa terkadang dalam melaksanakan proses pembelajaran online, jaringan tiba-tiba menjadi lamban, bahkan kuota internet merupakan momok utama yang berperan penting dalam pelaksanaan pembelajaran, habis ditengah jalan. Kendala yang ditemukan yakni penggunaan jaringan internet yang membutuhkan biaya dan kemampuan orang tua dalam memberikan fasilitas pendidikan secara online, kurangnya pembelajaran bersikap yang baik, kurangnya disiplin diri, serta lingkungan ketika terisolasi dirumah (Bao, 2020; Jones, \& Sharma, 2019; Obiakor, \& Adeniran, 2020; Purwanto, Pramono, Asbari, Santoso, Wijayanti,\&Hyun, 2020).

Penelitian yang dilakukan oleh Agus, dkk di kutip oleh Dewi (2020) yang berjudul "Studi Eksploratif Dampak Pandemi COVID-19 Terhadap Proses Pembelajaran Online di Sekolah Dasar" dampak COVID-19 terhadap proses pembelajaran online di sekolah dasar berdampak terhadap siswa, orang tua dan guru itu sendiri. Beberapa dampak yang dirasakan murid yaitu murid belum ada budaya belajar jarak jauh karena selama ini sistem belajar dilaksanakan adalah melalui tatap muka, murid terbiasa berada di sekolah untuk berinteraksi dengan teman- 
temannya, bermain dan bercanda gurau dengan temantemannya serta bertatap muka dengan para gurunya, dengan adanya metode pembelajaran jarah jauh membuat para murid perlu waktu untuk beradaptasi dan mereka menghadapi perubahan baru yang secara tidak langsung akan mempengaruhi daya serap belajar mereka. Dampak terhadap orang tua yaitu kendala yang dihadapi para orang tua adalah adanya penambahan biaya pembelian kuota internet bertambah, teknologi online memerlukan koneksi jaringan ke internet dan kuota oleh karena itu tingkat penggunaaan kuota internet akan bertambah dan akan menambah beban pengeluaran orang tua. Dampak yang dirasakan guru yaitu tidak semua mahir menggunakan teknologi internet atau media sosial sebagai sarana pembelajaran, beberapa guru senior belum sepenuhnya mampu menggunakan perangkat atau fasilitas untuk penunjang kegiatan pembelajaran online dan perlu pendampingan dan pelatihan terlebih dahulu. Jadi, dukungan dan kerjasama orang tua demi keberhasilan pembelajaran sangat dibutuhkan. Komunikasi guru dan sekolah dengan orang tua harus terjalin dengan lancar.

\section{B. Dampak Pandemik terhadap Guru}

Satrianingrum \& Prasetyo (2020) pandemi ini memberikan dampak bagi guru dalam proses pembelajaran secara online, karena guru tidak leluasa memantau perkembangan anak secara keseluruhan. Menurut Satrianingrum, mengontrol anak dari jarak jauh adalah sebuah keterbatasan, ditambah dengan adanya anak yang jarang dibimbing oleh orang tua dan juga kurangnya pemahaman orang tua terhadap perkembangan anak, sehingga proses pembelajaran sebagian besar tidak terlaksana secara maksimal. Selain itu, kurang optimalnya penyampaian materi pembelajaran yang disampaikan kepada murid, sehingga pembelajaran dirasa kurang bermakna bagi murid. Dalam penyampaian materi, guru juga terbatas metode ajar yang akan 
disampaikan, mengingat jumlah kuota yang dimiliki oleh orang tua murid dan guru, sehingga pembelajaran dilakukan dalam grup di aplikasi. Namun, walaupun begitu, tidak ada perubahan dalam banyaknya porsi kerja guru dalam menyiapkan proses pembelajaran yang terbaik bagi murid. Dalam temuan lain dari kasus pelaksanaan pembelajaran online adalah guru merasa bingung dan merasa repon yang diharapkan tidak pasti, sehingga apakah guru melakukan pembatasan peran atau harus melakukan perluasan peran secara online (Forkosh-Baruch,\& Hershkovitz, 2014). Dalam pelaksanaan pembelajaran secara online, banyak penelitian yang mengungkapkan bahwa pembelajaran ini lebih efiesien dalam biaya dan tenaga. Akan tetapi menurut Satrianingrum \& Prasetyo (2020) bahwa tidak semua murid berasal dari keluarga yang berada, apalagi pandemik ini membuat keluarganya susah mencari nafkah. Perlu adanya kreativitas dari guru dalam merencanakan instruksi online secara efektif. Gaya pengajaran dalam pembelajaran daring pun perlu diperluas, karena cukup berbeda dengan pembelajaran yang berada dalam ruangan (Purwanto, Pramono, Asbari, Santoso, Wijayanti, \& Hyun, 2020). Dalam pembelajaran dalam ruangan, bahasa tubuh guru, ekspresi wajah dan suara adalah hal yang utama. Namun, ketika beralih ke platform, mereka menyediakan terdapat berbagai menu yang dapat dibagikan, seperti teks, video, gambar, suara dan lainnya. Sehingga dalam pembelajaran daring guru harus memilih strategi yang tepat dalam menyampaikan materi (Bao, 2020). 


\section{Persepsi Guru terhadap Kesiapan Institusi Pendidikan dalam Mengimplementasikan E-Learning}

Table 4. Gambaran persepsi Guru terhadap Kesiapan Institusi Pendidikan dalam Menerapkan E-Learning

\begin{tabular}{lcccc}
\hline & \multicolumn{2}{c}{ Responses } & Mean & $\begin{array}{c}\text { Std. } \\
\text { Deviation }\end{array}$ \\
\hline & Ya & Tidak & & \\
\hline Perangkat elektronik pribadi & 89 & 3 & 1.03 & .179 \\
\hline Masalah akses internet & 64 & 28 & 1.30 & .463 \\
\hline $\begin{array}{l}\text { Pemanfaatan E-learning sebelum } \\
\text { pandemi }\end{array}$ & 33 & 59 & 1.64 & .482 \\
\hline $\begin{array}{l}\text { Subsidi internet yang disiapkan } \\
\text { oleh Institusi Pendidikan }\end{array}$ & 16 & 76 & 1.83 & .381 \\
\hline $\begin{array}{l}\text { Pembelajaran Asynchronous dan } \\
\text { synchronous harus di } \\
\text { implementasikan dalam proses } \\
\text { belajar-mengajar meskipun } \\
\text { wabah telah berakhir }\end{array}$ & 83 & 9 & 1.42 & .497 \\
\hline
\end{tabular}

Sebuah survey yang dilakukan oleh Husain et, al (2020) untuk mengetahui persepsi guru terhadap penerapan e-learning di masa pandemi yang dilakukan pada guru-guru di Maluku Utara menunjukkan bahwa lebih dari setengah peserta merespon positif kepemilikan perangkat elektronik pribadi. Diikuti oleh 83 responden yang percaya bahwa pembelajaran yang berbasis Asynchronous dan synchronous dianggap penting untuk diterapkan meskipun pandemi telah berakhir. Selain itu guru-guru dihadapkan dengan masalah signifikan yakni akses internet yang buruk. Bahkan guru berpendapat bahwa sebagian besar sekolah tidak memberikan subsidi berupa biaya internet tambahan dalam memfasilitasi proses belajar mengajar secara online. Sebagian besar guru menegaskan bahwa e-learning tidak pernah di terapkan dalam pengajaran sebelum adanya 
pandemi. Berdasarkan beberapa kendala yang di ungkapkan oleh para guru, berikut saran yang diberikan untuk mengatasi fenomena tersebut;

D. Gagasan-Gagasan Guru dalam Mengatasi Kendala Penerapan E-Learning

Tabel 5. Saran Guru dalam Mengatasi Kendala Penerapan e-learning

\begin{tabular}{cl}
\hline No & \multicolumn{1}{c}{ Suggestions } \\
\hline 1 & $\begin{array}{l}\text { Perbaikan infrastuktur dan ketersediaan perangkat } \\
\text { elektronik pembelajaran }\end{array}$ \\
\hline 2 & Tersedianya subsidi biaya internet oleh Institusi Pendidikan \\
\hline 3 & Kelayakan akses internet \\
\hline 4 & $\begin{array}{l}\text { Melakukan pelatihan secara berkala secara daring bagi } \\
\text { seluruh tenaga pendidik untuk meningkatkan kecakapan } \\
\text { penguasaan TIK }\end{array}$ \\
\hline 5 & $\begin{array}{l}\text { Melakukan sosialisasi untuk memperkenalkan system e- } \\
\text { learning }\end{array}$ \\
\hline 6 & $\begin{array}{l}\text { Mempersiapkan berbagai sumber belajar sebagai langkah } \\
\text { alternatif guna mengatasi keterbatasan internet di daerah } \\
\text { tertinggal }\end{array}$ \\
\hline 7 & $\begin{array}{l}\text { Membangun kerjasama dan komunikasi yang baik antar } \\
\text { orang tua, siswa dan guru }\end{array}$ \\
\hline 8 & $\begin{array}{l}\text { Mendorong siswa agar memiliki ketertarikan yang besar } \\
\text { untuk lebih aktif dalam pembelajaran online }\end{array}$ \\
\hline 9 & $\begin{array}{l}\text { Menyediakan waktu lebih untuk proses berlangsungnya e- } \\
\text { learning }\end{array}$ \\
\hline 10 & $\begin{array}{l}\text { Mengembangkan berbagai macam platform dan software } \\
\text { pembelajaran untuk mata pelajaran yang berorientasi pada } \\
\text { praktik lapangan }\end{array}$ \\
\hline &
\end{tabular}


Berdasarkan gagasan responden, dapat digambarkan bahwa fenomena utama yang harus ditangani adalah masalah teknis. Selain itu, guru menawarkan beberapa solusi untuk mengatasi beberapa masalah teknis dan kurangnya minat siswa dalam pembelajaran online. Misalnya, membangun kolaborasi, dan koordinasi di antara orang tua, guru, dan siswa dianggap sebagai solusi untuk mendorong siswa yang kurang tertarik pada pembelajaran ini. Dengan demikian, e-learning dapat berjalan dengan sukses. 


\section{BAB VI \\ PEMANFAATAN APLIKASI BERBASIS TEKNOLOGI DALAM PEMBELAJARAN DI MASA COVID-19}

Ketika Menteri Pendidikan dan Kebudayaan mengeluarkan Surat Edaran No 3 tahun 2020 tentang Pencegahan Covid-19 pada Satuan Pendidikan pada 9 Maret 2020; Surat Edaran Menteri Kesehatan No HK.02.01/MENKES/199/2020 pada 12 Maret 2020; dan Surat Edaran Sekjen Kemendikbud No 36603/A.A5/OT/2020 pada 15 Maret 2020, atas dasar itulah pilihan bertindak cepat harus segera dilakukan. Di antara kebijakan yang diambil ialah menonaktifkan kegiatan perkuliahan di lingkungan kampus untuk melakukan sterilisasi serta melakukan karantina mandiri mahasiswa, dosen, dan tenaga kependidikan, termasuk tidak melakukan aksi pertemuan di tempat umum sekaligus menghidupkan perkuliahan dan bimbingan tesis/skripsi secara daring. Kebijakan tersebut aktif mulai 16 Maret hingga 3 April 2020. Tentu ada kesulitan ketika kebijakan baru ini diterapkan. Diterangkan juga bahwa penghentian tatap muka secara langsung bukan berarti bahwa perkuliahan dan bimbingan tidak dilakukan. Namun, dengan tradisi perkuliahan secara konvensional, pilihan melakukan pembelajaran secara online dari kediaman masingmasing tidak mudah dilakukan. Pertama, memerlukan kesiapan perangkat dan tentu paket data internet yang masih dikelola secara mandiri. Kedua, tidak semua dosen dan mahasiswa siap mengoperasikan sistem pembelajaran daring dengan cepat, termasuk juga mempersiapkan bahan perkuliahan secara digital. Ada banyak inisiatif yang bisa dilakukan untuk tetap bersiasat di tengah kesulitan. Di dunia pendidikan, termasuk pendidikan tinggi, bisa memanfaatkan kemerdekaan berpikirnya untuk lepas dari masalah dan menatap masa depan dengan optimistis. Salah satu yang bisa dilakukan perguruan tinggi ialah 'me-lockdown' perkuliahan secara fisik--tentu temporer sifatnya--dan memaksimalkan 'open up' kuliah model lain dengan memanfaatkan teknologi virtual dan digital. Revolusi industri 4.0 memungkinkan kita melakukan inisiatif terbarukan untuk 
memaksimalkan fungsi komunikasi, transfer informasi, dan pengetahuan. Dunia boleh mewabah dan terimpit oleh pertumbuhan yang melambat, tapi dunia pendidikan harus terus berlari demi melanjutkan peradaban (MediaIndonesia.com, 10 Oktober, 2020).

\section{A. Upaya Peningkatan Kualitas Proses Belajar dari Rumah}

Menanggapi berbagai keluhan terkait kendala akses internet maupun aktivitas belajar yang memberatkan pendidik maupun peserta didik, Kemendikbud mengimbau untuk mewujudkan pendidikan bermakna yang tidak hanya fokus pada capaian aspek akademik atau kognitif. Secara lebih jelas aturan mengenai proses belajar dari rumah diatur dalam Surat Edaran Mendikbud No. 4 Tahun 2020 tentang Pelaksanaan Kebijakan Pendidikan dalam Masa Darurat Penyebaran Coronavirus Disease (Covid-2019). Poin 2 surat edaran tersebut menjelaskan proses belajar dari rumah dilaksanakan dengan ketentuan: pertama, dilaksanakan untuk memberikan pengalaman belajar yang bermakna bagi siswa, tanpa terbebani tuntutan menuntaskan seluruh capaian kurikulum untuk kenaikan kelas maupun kelulusan. Kedua, difokuskan pada pendidikan kecakapan hidup, antara lain mengenai pandemi Covid-19. Ketiga, aktivitas dan tugas pembelajaran dapat bervariasi antarsiswa, sesuai minat dan kondisi masing-masing, termasuk mempertimbangkan kesenjangan akses/fasilitas belajar di rumah. Keempat, bukti atau produk aktivitas belajar dari rumah diberi umpan balik yang bersifat kualitatif dan berguna dari guru, tanpa diharuskan memberi skor/nilai kuantitatif. Plt. Dirjen PAUD Dikdasmen Kemendikbud, Harris Iskandar menjelaskan bahwa guru tidak harus terpaku pada pembelajaran daring dan pemberian tugas (cnnindonesia.com, 31 Maret 2020).

Guru diharapkan kreatif dan inovatif dalam mengeksplor kegiatan belajar yang menyenangkan, terutama karena keterbatasan teknologi dan koneksi internet. Sebagai contoh pembelajaran melalui projek pembuatan hand sanitizer berbahan rempah tradisional yang dapat langsung digunakan 
siswa. Sejalan dengan hal tersebut, dinas pendidikan dan pimpinan perguruan tinggi diharapkan memberikan pedoman atau prosedur teknis pelaksanaan pembelajaran online sesuai dengan kondisi setempat sehingga implementasinya tidak menjadi beban tambahan (Media Indonesia, 6 April 2020).

Guna mengatasi keterbatasan akses internet, pembelajaran tanpa internet dapat dilakukan untuk kondisi tertentu yang tidak memungkinkan menggunakan internet. Namun demikian, Kemendikbud terus memperbesar dukungan mitra swasta guna menyukseskan PJJ dengan memanfaatkan platform teknologi selama masa darurat Covid19 (kompas.com, 30 Maret 2020; kemdikbud.go.id, 30 Maret 2020). Dalam hal ini Ditjen Dikti mendukung dan memfasilitasi pelaksanaan pembelajaran online lebih luas, bekerja sama dengan Kominfo dan provider layanan telekomunikasi. Berkat upaya tersebut masyarakat dapat mengakses beragam konten belajar jarak jauh melalui berbagai platform seperti Rumah Belajar, Kelas Pintar, Quipper School, Ruang Guru, dan Zenius untuk jenjang PAUD dan Dikdasmen serta Sistem Pembelajaran dalam Jaringan (SPADA) untuk jenjang Pendidikan Tinggi.

Sebagai bentuk dukungan, Komisi X DPR RI mendorong prioritas Rumah Belajar untuk dapat bekerja sama dengan Lembaga Penyiaran Publik (LPP) TVRI dan RRI agar sistem pembelajaran berbasis IT ini bisa menjangkau wilayah Indonesia secara lebih merata. Merespon upaya tersebut, mulai Senin, 13 April 2020 LPP TVRI menayangkan konten program belajar dari rumah yang rencananya akan berjalan hingga tiga bulan ke depan.

Dalam rangka peningkatan kualitas PJJ secara keberlanjutan beberapa hal penting yang harus diupayakan, antara lain, pertama, lembaga pendidikan harus mulai meningkatkan sarana dan prasarana pendukung pembelajaran daring seperti infrastruktur, Learning Management System (LMS), dan repositori yang memadai. Kedua, peningkatan kapasitas pendidik yang mendukung pelaksanaan PJJ, 
misalnya peningkatan kompetensi dalam menyiapkan media dan konektivitas serta pengelolaan pembelajaran secara online. Ketiga, perluasan dukungan platform teknologi secara berkesinambungan untuk mendukung PJJ. Dukungan berbagai platform teknologi untuk kegiatan pembelajaran diharapkan dapat terus berlanjut hingga setelah masa darurat Covid-19 telah berakhir. Beberapa upaya tersebut dilakukan untuk mempersiapkan agar PJJ dapat terlaksana secara optimal, bukan hanya dalam situasi darurat tetapi juga untuk peningkatan kualitas pendidikan di tengah pesatnya perkembangan teknologi (Arifa, 2020).

\section{B. Pemanfaatan E-Learning Di Sekolah Dasar}

Dewi (2020) Dengan munculnya pandemik COVID-19 kegiatan belajar mengajar yang semula dilaksanakan di sekolah kini menjadi belajar di rumah melalui daring. Pembelajaran online dilakukan dengan disesuaikan kemampuan masingmaisng sekolah. Belajar online dapat menggunakan teknologi digital seperti google classroom, rumah belajar, zoom, video converence, telepon atau live chat dan lainnya. Namun yang pasti harus dilakukan adalah pemberian tugas melalui pemantauan pendampingan oleh guru melalui whatsapp grup sehingga anak betul-betul belajar. Kemudian guru-guru juga bekerja dari rumah dengan berkoordinasi dengan orang tua, bisa melalui video call maupun foto kegiatan belajar anak dirumah untuk memastikan adanya interaksi antara guru dengan orang tua.

Dewi (2020) Beberapa sekolah yang belum dapat menyelenggarakan KBM online dapat mengembangkan kreativitas guru untuk memanfaatkan media belajar alternatif selama peserta didik belajar di rumah. Mereka dapat menggunakan sumber belajar yang ada yaitu buku siswa sesuai dengan tema-tema yang diajarkan sesuai jadwal yang telah dibuat sebelumnya. Pembelajaran berbasis online learning menunjukkan katerogisasi setuju. Hal ini ditunjukkan setelah mengikuti pembelajaran berbasis online learning, para siswa semakin semangat mengikuti pembelajaran khususnya dalam 
pembelajaran IPA dan Para siswa tidak merasa bosan saat pembelajaran berlangsung. (Sobron et al., 2019) Menurut Vicky dan Putri (Wicaksono \& Rachmadyanti, 2016) Penyelenggaran google classroom di sekolah dasar tanpa menyampingkan pembelajaran konvensional yang dilakukan. Hal ini merupakan kelebihan blended learning, dimana menggabungkan dua metode pembelajaran konvensional dan online untuk membuat siswa merasa nyaman dan aktif dalam mengonstruksi pengetahuannya. Survei yang dilakukan Lenny N Rosalin Deputi Menteri PPPA Bidang Tumbuh Kembang Anak juga menunjukan harapan anak tentang program belajar dirumah. Anak-anak yang mengikuti survei dari 29 provinsi berharap agar sekolah tidak terlalu banyak memberikan tugas dan komunikasi dua arah antara guru dan murid dirasa lebih efektif (Ade Nasihudin Al Ansori, 2020).

Menurut Heru Purnomo dalam pikiran rakyat media network pembelajaran jarak jauh dengan penerapan metode pemberian tugas secara online bagi para siswa melalui whatsapp grup dipandang efektif dalam kondisi darurat karena adanya virus corona seperti sekarang ini. Banyak guru mengimplementasikan dengan cara-cara beragam belajar di rumah, dari perbedaan belajar itu basisnya tetap pembelajaran secara online. Ada yang menggunakan konsep ceramah online, ada yang tetap mengajar di kelas seperti biasa tetapi divideokan kemudian dikirim ke aplikasi whatsapp siswa, ada juga yang memanfaatkan konten-konten gratis dari berbagai sumber (Ashari, 2020). Menurut Putra Wijaya dalam (Suryawan, 2020) belajar dirumah tidak menjadi masalah karena pembelajaran bisa dilakukan kapan dan dimana saja, apalagi sudah didukung dengan sistem online. Jadi proses pembelajaran bisa terjadi di rumah, di sekolah maupun di masyarakat. Oleh karena itu semua bisa berjalan dengan baik, dengan dukungan fasilitas seperti internet (Dewi, 2020).

Titik Kartikawati dalam guru SD Negeri 09 Sanggau, Kalimantan Barat mengatakan pembelajaran dirumah tetap dapat dilaksanakan. Ia mulai membuka kelas dari pukul 07.00 
hingga 12.00. Dalam hal pelaksanaan belajar di rumah guru meminta bantuan orang tua atau kakak siswa sebagai narasumber yang langkah-langkahnya telah diberikan melalui grup whatsapp. Untuk laporan pelaksanaan pembelajaran dapat berupa foto atau video yang harus diunggah melalui grup. Berbeda dengan Timur Setiawan menyampaikan beberapa metode pembelajaran secara online yang telah diterapkan yaitu pembelajaran melalui portal rumah belajar dan penyampaian materi melalui file word yang dibagikan melalui media sosial whatsapp. (Pengelola Web Kemendikbud, 2020) Pembelajaran online saat ini dijadikan solusi dalam masa pandemi COVID-19. Tetapi pembelajaran online tidak mudah seperti yang dibayangkan. Titi salah satu tenaga pendidik disalah satu sekolah dasar mengatakan dalam pembelajaran kelas 2 SD dia menggunakan zoom untuk meeting (pertemuan) tatap muka selayaknya di kelas. Tetapi tidak semua anak bisa akses karena ada yang orang tuaanya masih kerja, ada juga orang tua yang gagap teknologi. Selain itu titik juga mencari alternatif lain media pembelajaran online dengan google doc, memberikan tautan yang berisi materi pelajaan sekaligus tugas serta batas waktu pengerkaan dinilai lebih bisa mengkomodir kebutuhan orang tua dan anak, ini dapat membantu penilai harian, nilai bisa langsung masuk berkas fom google. Lain halnya dengan Rita guru kelas 3 sekolah dasar. Di sekolah tempat Ritza bekerja, guru diwajibkan memberikan materi pelajaran dan tugas melalui alamat surat elektronik milik orang tua. Cara ini dinilai Ritza tak berjalan dengan efektif. Mengirimkan dokumen materi berupa power point, lalu anak mengerjakan dilaptop, dicetak atau tulis tangan lalu dikirim lewat whatsapp dinilai lebih efektif menurut Ritza. (Tim CNN Indonesia, 2020). 


\section{Pemanfaatan Aplikasi Pembelajaran di Sekolah Menengah dan Sekolah Menengah Atas (Studi Kasus di Maluku Utara)}

Table 2. Jenis Platform Pembelajaran yang Diimplementasikan dalam E-Learning

\begin{tabular}{lr}
\hline & \multicolumn{1}{c}{$\begin{array}{c}\text { Valid } \\
\text { Percent }\end{array}$} \\
\hline Jenis Aplikasi & 14.1 \\
\hline Whatsapp & 6.5 \\
\cline { 2 - 2 } Zoom & 17.4 \\
\cline { 2 - 2 } Messenger & 5.4 \\
\cline { 2 - 2 } Loogle Classroom & 5.4 \\
Moodle & 1.1 \\
Email & 1.1 \\
Mixture Platforms & 41.3 \\
Did Not Apply any e- & 7.6 \\
\cline { 2 - 2 } Learning & \\
\cline { 2 - 2 } Total & 100.0 \\
\hline
\end{tabular}

Tabel ini menunjukkan bahwa sebagian besar guru, baik guru sekolah menengah maupun sekolah menengah atas memanfaat berbagai jenis platform pembelajaran berbasis jaringan. Sebagian besar cenderung menggunakan platform penggabungan dari berbagai aplikasi, penggunaan platform campuran mencapai persentase $41.3 \%$. Platform yang dianggap memberikan banyak manfaat didominasi oleh aplikasi FacebookMessenger, dengan maksimum 17,4 persen. Selain itu, 13 persen pengguna memiliki ketertarikan dalam menggunakan perangkat lunak Whatsapp selama proses belajar-mengajar online berlangsung. Disamping itu, 6,5 persen guru menerapkan e-learning dengan memanfaatkan aplikasi Zoom. Pada saat yang sama, guru dan siswa cenderung menggunakan Google Classroom dan Line dengan masing-masing 5,5 persen, sementara perangkat pembelajaran seperti Moodle dan E-mail kurang diminati oleh guru dan siswa dalam pembelajaran, 
dengan masing-masing persentase yakni sebesar 1,1 persen. Sayangnya, 7,6 persen guru di Maluku Utara teridentifikasi tidak kurang mengambil perhatian terhadap e-learning. Dengan kata lain, mereka tidak menerapkan jenis perangkat elektronik lainnya untuk mendukung kelangsungan proses belajarmengajar selama penyebaran penyakit Virus Corona.

Table 3. Jenis-Jenis Aplikasi Pembelajaran, Kecakapan Soft-Skill

\begin{tabular}{lr}
\multicolumn{2}{c}{ Pengguna E-learning } \\
\hline & $\begin{array}{c}\text { Valid } \\
\text { Percent }\end{array}$ \\
\hline Pengklasifikasian Aplikasi & \\
\hline Single Platform & 51.1 \\
\cline { 2 - 2 } Mixture Platforms & 41.3 \\
\cline { 2 - 2 } Tidak menerapkan E- & 7.6 \\
Learning & \\
\hline Kecakapan Soft-skill & 3.3 \\
\hline Limited user & 41.3 \\
Modest user & 48.9 \\
Competent user & 6.5 \\
\cline { 2 - 2 } Expert user &
\end{tabular}

Data menunjukkan bahwa 51,1 persen pengguna menerapkan single platform, termasuk Whatsapp, Zoom, Messenger, Google Classroom, Line, Moodle, atau Email. 41,3 persen guru menggunakan lebih dari satu platform atau platform campuran. Ditemukan bahwa sisanya (7,6 persen) tidak menerapkan e-learning atau tidak menggunakan perangkat elektronik apa pun dalam kegiatan proses belajar-mengajar. Namun demikian, 48,9 persen pengguna dianggap kompeten atau sangat baik dalam mengoperasikan perangkat teknologi, 41.3\% diklasifikasikan sebagai pengguna yang memiliki kemampuan mengoperasikan perangkat teknologi pada kategori sedang, 6,5\% diidentifikasi ahli untuk mengoperasikan peralatan teknologi, dan $3,3 \%$ dikelompokkan memiliki 
kemampuan terbatas atau kurang memiliki keahlian dalam mengoperasikan perangkat teknologi.

\section{Pemanfaatan e-learning di Perguruan Tinggi}

Tabel 6. Aplikasi yang Paling diminati untuk Digunakan dalam Proses Belajar Mengajar di Universitas Pasifik Morotai disaat Lock Down

\begin{tabular}{llcc}
\hline & & Cumulative \\
Valid & Percent & Percent \\
\cline { 2 - 3 } & E-Learning UNIPAS & 8.6 & 8.6 \\
\cline { 2 - 3 } & Email & 7.1 & 15.7 \\
\cline { 2 - 3 } & Google-classroom & 4.3 & 20.0 \\
\cline { 2 - 3 } & $\begin{array}{l}\text { Google-classroom, Google- } \\
\text { hangouts }\end{array}$ & 1.4 & 21.4 \\
\cline { 2 - 3 } & Messenger & 2.9 & 24.3 \\
\cline { 2 - 3 } & Screencast O Matic, Google- & 2.9 & 27.1 \\
& form & & \\
\cline { 2 - 4 } & Tidak menerapkan e-learning & 48.6 & 75.7 \\
\cline { 2 - 3 } & Whatsapp & 7.1 & 82.9 \\
\cline { 2 - 3 } & Whatsapp, Email & 1.4 & 84.3 \\
\cline { 2 - 3 } & Whatsapp, Messenger & 8.6 & 92.9 \\
\cline { 2 - 3 } & Whatsapp, Messenger, Email & 5.7 & 98.6 \\
\cline { 2 - 3 } & Zoom, Google-Hangout & 1.4 & 100.0 \\
\cline { 2 - 3 } & Total & 100.0 & \\
\hline
\end{tabular}

Tabel di atas menunjukkan bahwa item "tidak menerapkan pembelajaran e-learning" yakni pilihan yang paling disukai, dengan $48,6 \%$ responden memilih item ini. Rata-rata dosen tidak merancang materi dan menyampaikan materi melalui kelas online meskipun Lembaga Pendidikan Tinggi telah mengumumkan kepada seluruh tenaga pengajar dan pendidik untuk melakukan kelas online guna mencegah penyebaran virus Coron. Selain itu, aplikasi yang dikembangkan oleh Universitas Pasifik Morotai ini dikenal 
sebagai E-learning Unipas, dan elaborasi baik Whatsapp maupun Messenger menjadi aplikasi yang paling diminati oleh mahasiswa dan dosen dalam menjalankan proses belajar mengajar. Sebagian besar pengguna menggunakan aplikasi media sosial untuk mendukung aktivitas belajar selama masa pandemi, dengan masing-masing 8,6\% pengguna. Posisi ketiga ditempati oleh aplikasi Whatsapp dan Email, sebesar 7,1\%. Kemudian diikuti oleh aplikasi Whatsapp, Messenger, dan Email. Sebagian besar pengguna memanfaatkan media sosial sebagai media pembelajaran secara bersamaan, sedangkan 5,7\% dari pengguna tertarik untuk mengadopsi media sosial tersebut. Aplikasi ketiga yang familiar digunakan adalah aplikasi Googleclassroom. Dapat dilihat bahwa 4,1\% pengguna menikmati penerapan aplikasi ini untuk proses belajar mengajar. Aplikasi kedua yang terbawah adalah penggunaan aplikasi Messenger, screencast $O$ Matic dan Google-form secara bersama-sama, dengan persentase masing-masing sebesar 2,9\%. Sedangkan aplikasi yang paling kurang diminati oleh akademisi yakni kombinasi antara Zoom dan Google-hangout, serta kombinasi dari Google-kelas dan Google-hangout, dengan persentase 1,4\%, masing-masing.

Hasil penelitian lain yang diungkapkan oleh Hakim \& Mulyapradana (2020) melalui penelitian "Pengaruh Penggunaan Media Daring dan Motivasi Belajar Terhadap Kepuasan Mahasiswa Pada Saat Pandemi Covid-19", dimana Responden riset ini dilakukan di kampus ITS NU Pekalongan Program Studi Teknologi Informasi dan Politeknik Pusmanu Program Studi Administrasi Perkantoran berjumlah 125 responden dan data riset yang diperoleh dilakukan dengan cara penyebaran angket melalui google form. Dari penyebaran kuesioner tersebut diperoleh hasil deskripsi responden sebagai berikut: terdapat 3 kategori golongan usia dalam responden di riset ini yakni golongan usia 17-22 tahun, 23-28 tahun dan 2934 tahun. Penyebaran responden tersebut antara lain sebanyak 116 responden $(92,8 \%)$ yang berusia 17-22 tahun, sebanyak 6 responden $(4,8 \%)$ yang berusia $23-28$ tahun dan yang terakhir 
sebanyak 3 responden (2,4\%) yang berusia 29-34 tahun. Hal ini dapat terlihat bahwa mayoritas usia responden dalam riset ini berusia antara 17 tahun hingga 22 tahun. Sedangkan responden berdasarkan jenis kelamin sebanyak 54 responden $(43,2 \%)$ adalah laki-laki dan sisanya yang berjumlah 71 responden (56,8\%) adalah perempuan. Dan data responden berdasarkan institusi perguruan tinggi yakni responden yang kuliah di Politeknik Pusmanu sebanyak 69 responden $(55,2 \%)$ dan ITS NU Pekalongan sebanyak 56 responden $(44,8 \%)$. Dalam riset ini peneliti melakukan observasi awal mengenai media pembelajaran yang sering digunakan oleh mahasiswa dalam kuliah online dari data yang diperoleh bahwa media pembelajaran melalui google classroom menjadi pilihan utama dalam kuliah online dapat terlihat bahwa dari 125 responden ini sebanyak 58 responden $(46,4 \%)$ yang memilih google classroom sebagai media kuliah online yang dipilih. Selanjutnya sebanyak 52 responden $(41,6 \%)$ mahasiswa memilih menggunakan media whatsapp group dalam kuliah online dan media Zoom sebanyak 9 responden $(7,2 \%)$ serta yang terakhir adalah media google meeting diperoleh sebanyak 6 responden $(4,8 \%)$. Dari data tersebut diperoleh mahasiswa memiliki antusias untuk kuliah online dengan menggunakan media google classroom dan whatsapp. Berdasarkan hasil wawancara yang dilakukan peneliti kepada beberapa responden dalam riset ini mengatakan bahwa media google classroom memiliki fiture yang menarik seperti ada pengiriman materi pembelajaran yang dilakukan oleh dosen pengampu yang dapat diakses oleh mahasiswa dengan mudah, mahasiswa dapat membuka materi yang dikirim oleh dosen di waktu kapan pun dan mudah dalam penggunanya terutama pada saat penyampaian materi serta media ini menyediakan fiture tugas atau lembar kerja dimana mahasiswa dapat secara langsung melihat nilai yang diberikan oleh dosen pengampu terhadap tugas yang diberikan. Disamping itu, google classroom terdapat fiture komunikasi atau (chat room) yang dapat digunakan oleh dosen maupun mahasiswa untuk berkomunikasi. Media pembelajaran selanjutnya yakni 
whatsapp group, media ini menjadi pilihan responden dalam memilih media pembelajaran karena untuk media pembelajaran ini biaya untuk kuota jaringan tidak terlalu banyak yang harus dikeluarkan oleh mahasiswa karena hampir sebagian besar provaider komunikiasi memberikan paket gratis dalam penggunaan whatsapp sehingga ini menjadi alasan mahasiswa tertarik untuk menggunakan whatsapp group sebagai media pembelajaran. Sedangkan untuk media lainnya berdasarkan hasil wawancara dikatakan bahwa media pembelajaran tersebut sangat menguras biaya kuota dalam kegiatan kuliah online karena media tersebut memiliki fiture hanya sebagai telekonferensi atau pertemuan berbasis elektronik secara langsung yang melibatkan dua atau lebih partisipan. 


\section{DAFTAR PUSTAKA}

Abidah, A., Hidaayatullaah, H. N., Simamora, R. M., Fehabutar, D., \& Mutakinati, L. (2020). The Impact of Covid-19 to Indonesian Education and Its Relation to the Philosophy of "Merdeka Belajar." Studies in Philosophy of Science and Education, 1(1),

$38-49$. https://doi.org/10.46627/sipose.v1i1.9

Adawi, R. (2016). Pembelajaran berbasis E-Learning. digilib.unimed.ac.id/541/1/Pembelajaran Berbasis ELearning.pdf

Ade Nasihudin Al Ansori. (2020). Belajar di Rumah Akibat Corona COVID-19, Ini Pendapat dan Harapan Anak Indonesia. Liputan6.

https://m.liputan6.com/health/read/4224969/b elajardi-rumah-akibat-corona-covid-19-inipendapat-danharapan-anak-indonesia

Ahmad, I., \& Ahmad, S. (2019). The Mediation Effect of Strategic Planning on The Relationship Between Business Skills and Firm's Performance: Evidence from Medium Enterprises in Punjab, Pakistan. Opcion, 35(24), 746-778

Ahmed, S., Shehata, M. H., \& Hasanien, M. (2020). Emerging Faculty Needs for Enhancing Student Engagement on Virtual Platform. MedEdPublish. https://doi.org/http://doi.org/10.15694/mep.2020.0000 75.1

Algahtani, A.F. (2011). Evaluating the Effectiveness of the E-learning Experience in Some Universities in Saudi Arabia from Male Students' Perceptions, Durham theses, Durham University.

Almosa, A. (2002). Use of Computer in Education, (2nd ed), Riyadh: Future Education Library.

Almosa, A. \& Almubarak, A. (2005). E-learning Foundations and Applications, Saudi Arabia: Riyadh. 
Alruwais, N., Wills, G., \& Wald, M. (2018). Advantages and Challenges of Using E-Assessment. International Journal of Information and Education Technology, 8(1), 34-37. https://doi.org/10.18178/ijiet.2018.8.1.1008

Amer, T. (2007). E-learning and Education, Cairo: Dar Alshehab Publication.

Anhusadar, L. O. (2020). Persepsi mahasiswa PIAUD terhadap kuliah Online di Masa Pandemik COVID-19. Kindergarten: Journal of Islamic Early Childhood Education, 3(1), $44-$

58. https://doi.org/https://dx.doi.org/10.2414/kjiece.v3i1. 9609

Arif, B., \& Wahyu, P. (2014). Sistem Broadcast Proses Belajar Mengajar dengan Synchronous dan Asynchronous. Jurnal Sarjana Teknik Informatika, 2(1), 78-90. https://doi.org/10.12928/jstie.v2i1.2605

Arifa, F. N. (2020). Tantangan Pelaksanaan Kebijakan Belajar Dari Rumah dalam Masa Darurat COVID-19. Bidang Kesejahteraan Sosial Kajian Singkat Terhadap Isu Aktual dan Strategi, 12(1), 1-7.

Ashari, M. (2020). Proses Pembelajaran Daring di Tengah Antisipasi Penyebaran Virus Corona Dinilai Belum Maksimal. PikiranRakyatcom. https://www.pikiranrakyat.com/pendidikan/pr01353818/prosespembejalaran-daring-di-tengahantisipasipenyebaran-virus-corona-dinilaibelummaksimal

Asif, A. R., \& Rahmadi, F. A. (2017). Hubungan tingkat Kecanduan Gadget dengan Gangguan Emosi dan Perilaku Remaja Usia 11-12 Tahun (Doctoral dissertation, Faculty of Medicine).

Astuti, P., \& Febrian, F. (2019). Blended Learning Syarah: Bagaimana Penerapan dan Persepsi Mahasiswa. Jurnal Gantang, $4(2)$,

111-119.

https://doi.org/10.31629/jg.v4i2.1560 
Bandri, S., Rukun, K., Sukardi., Verawardina, U., \& Ramadhani, D. (2020). The Validity of the Model of Employability Skills Requiredfor Graduates to Enter the Workplace. Test Engineering \& Management, 83, 1638-1642.

Bao, W. (2020). COVID-19 and Online Teaching in Higher Education: A Case Study of Peking University. Pedagogical Research, 5(4), 113-115. https://doi.org/https://doi.org/10/1002/he2.191

Behnam, A. (2012). The Effect of Information and Communication Technology on Learning Level, Improvement of TeachingLearning Process and Information Literacy. Retrieved 5/3/2014 http://www2.atfmag.info/?p=2729, [Persian].

Crews, T. B., \& Curtis, D. F. (2011). Online Course Evaluations: Faculty Perspective and Strategies for Improved Response Rates. Assessment and Evaluation in Higher Education, 36(7), 865-878. https://doi.org/10.1080/02602938.2010.493970

Darmayanti, T., Setiani, M. Y., \& Oetojo, B. (2007). E-Learning Pada Pendidikan Jarak Jauh: Konsep Yang Mengubah Metode Pembelajaran Di Perguruan Tinggi Di Indonesia. Jurnal Pendidikan Terbuka Dan Jarak Jauh, 8, 99-113.

Dewi, W. A. F. (2020). Dampak COVID-19 Terhadap Implementasi Pembelajaran Daring Di Sekolah Dasar. EDUKATIF: Jurnal Ilmu Pendidikan, 2(1), 55-61. https://core.ac.uk/reader/322536540

Donovan, J., Mader, C., \& Shinsky, J. (2007). Conline vs. Traditional Course Evaluation Formats: Student Perceptions. Journal of Interactive Online Learning, 6(3), 158-180.

https://www.ncolr.org/jiol/issues/pdf/6.3.2.pdf

Drago, W. A., \& Wagner, R. G. (2004). Vark preffered Learning Styles and Online Education. Management Research News, 27, 113.

https://doi.org/https://doi.org/10.1108/0140917041078 211 
Dublin, L. (2003). If You Only Look Under the Street Lamps or Nine E-Learning Myths. The E-Learning developers journal. http://www.eLearningguild.com.

Faraj Allahi, M., \& Zarif Sanayei, N. (2009). Education Based on Information and Communication Technology in Higher Education. Journal of Education strategies, 4(2), 167-171, [Persian]

Feladi, V., Hendriyani, Y., Dewi, I. P., Darni, R., \& Verawadina, U. (2020). The Profile of Technological Pedagogical and Content Knowledge of Information and Communication Technology Teachers. Test Engineering \& Management, 83, 1666-1673.

Fitrah Hermawan. (2020). Covid-19 dan Pembelajaran Daring. Sumber: https://mediaindonesia.com/read/detail/29896 4-covid-19-dan-pembelajaran-daring

García-Martínez, I., Fernández-Batanero, J. M., Sanchiz, D. C., \& de la Rosa, A. L. (2019). Using Mobile Devices for Improving Learning Outcomes and Teachers' Professionalization. Sustainability (Switzerland), 11(24), 1-12. https://doi.org/10.3390/su11246917

Ghasem tabar, A. (2010). History of E-Learning in World and Iran. Retrieved 5/3/2014, 2014 http://mokarameh88.blogfa.com/post-2.aspx

Hakim, M., \& Mulyapradana, A. (2020). Pengaruh Penggunaan Media Daring dan Motivasi Belajar Terhadap Kepuasan Mahasiswa Pada Saat Pandemi Covid-19. Jurnal Sekretari Dan Manajemen, 4(2), 154-160. https://doi.org/https://doi.org/10.31294/widyacipta.v $4 \mathrm{i} 2.8853$

Hartanto, W. (2016). Penggunaan E-Learning Sebagai Media Pembelajaran. Jurnal Pendidikan Ekonomi, 10(1), 1-18. https://jurnal.unej.ac.id/index.php/JPE/article/view/3 438 
Hattangdi, A., \& Ghosh, A. (2008). Enhancing the Quality and Accessibility of Higher Education through the Use of Information and Communication Technology Paper Presented at the 11th Annual Convention of the Strategic Management Forum (SMF), Kanpur, India. Retrieved from http://www.iitk.ac.in/infocell/announce/convention/p apers/Strategy\%20Learning-01-

Ashish\%20Hattangdi,\%20\%20Atanu \%20Ghosh.pdf

Harvard University. (2020). Coronavirus (COVID-19). Accessed: March 28, 2020: https://www.harvard.edu/coronavirus.

Hendriyani, Y., Ramadhani, D., Nasution, T., Susanti, W., \& Verawardina, U. (2020). Examining Career Development of Informatics Engineering Vocational Education Students in the Industrial Revolution 4.0. International Journal of Innovation, Creativity and Change, 11(4), 275-298.

Herliandry, L. D., Nurhasanah., Suban, M. E., \& Kuswanto, H. (2020). Pembelajaran pada masa pandemi COVID-19. Jurnal Teknologi Pendidikan, 22(1), 65-70. https://doi.org/http://doi.org/10.21009/jtp.v22i1.15286

Hershkovitz, A., Elhija, M. A., Zedan, D. (2019). WhatsApp Is The Message: Out of Class Communication, Student-Teacher Relationship, and Classroom Enviroment. Journal of Information Technology Education: Research, 18.

Hodavand, S. (2008). Analyzing E-Learning in Iran. Retrieved $5 / 23 / 2014$ from http://www.mrfi.ir/kol/maghalat/Elearning/4.htm

Husain, B. Idi, YN. Masri, M. (2020). Teachers' perceptions on adopting e-learning

During covid-19 outbreaks; advantages, Disadvantages, suggestions. Jurnal Tarbiyah 27 (2), 41-57. DOI: 10.30829/tar.v27i2.738.

http://jurnaltarbiyah.uinsu.ac.id/index.php/tarbiyah 
James, G. (2002). Advantages and Disadvantages of Online Learning. Retrieved 5/18/2014 http://www.comminit.com/ict-4development/node/210058.

J. Ridgway, S. McCusker, and D. Pead. (2004). Literature Review of E-Assessment. Bristol.

Jones, K., \& Sharma, R. (2019). Reimagining A Future for Online Learning in the Post-COVID era. SSRN Electronic Journal. https://doi.org/10.2139/ssm.357831

Jordan, S., \& Mitchell, T. (2009). e-Assessment for Learning? The Potential of Short-Answer Free-Text Questions with Tailored Feedback. British Journal of Educational Technology, 40(2), 371-385. https://doi.org/10.1111/j.1467-8535.2008.00928.x

Karimi, A. (2007).Studying Factors Influencing the Use of Information Technology in Scientific and Practical Education. (Master's Thesis). University of Tehran, Iran.

Kayimbasioglu, D., Oktekin, B., \& Haci, H. (2016). Integration of Gamification Technology in Education. Procedia Computer Science, $\quad 102$ (August), 668-676. doi.org/10.1016/j.procs.2016.09.460

Kearns, L. (2012). Student Assessment in Online Learning: Challenges and Effective Practices. Jolt.Merlot.Org, 8(3), 198-208.

Khaleghi, E. (2010). E-learning. Retrieved 05/18/2014, from http:// www.guilan.ac.ir/news/index.php?a=00040http: //jolt.merlot.org/vol8no3/kearns_0912.htm

Kim, Y., Wang, Y., \& Oh, J. (2016). Digital Media Use and Social Engagement: How Social Media and Smartphone Use Influence Social Activities of College Students. Cyberpsychology, Behavior, and Social Networking. https://doi.org/10.1089/cyber.2015.0408 
Klein, D. \& Ware, M. (2003). E-Learning: New Opportunities in Continuing Professional Development. Learned Publishing, 16 (1) 34-46.

Kuo, Y. C., Walker, A. E., Schroder, K. E. E., \& Belland, B. R. (2014). Interaction, Internet Self-Efficacy, and Self-Regulated Learning as Predictors of Student Satisfaction in Online Education Courses. Internet and Higher Education. https://doi.org/10.1016/jiheduc.2013.10.001

Kusuma, J. W., \& H. (2020). Platform Whatsapp Grup dan Webinar Zoom dalam Pembelajaran Jarak Jauh pada Masa Pandemik COVID-19. Jurnal Ilmiah Pendidikan Matematika, 5(1), 97. https://doi.org/10.26877/jipmat.v5i1.5942

Kwon, M., Lee, J. Y., Won, W. Y., Park, J. W., Min, J. A., Hahn, C., ... Kim, D. J. (2013). Development and Validation of a Smartphone Addiction Scale (SAS). PLoS ONE. https://doi.org/10.1371/journal.pone.0056936

Lau, W. W. F. (2017). Effects of Social Media Usage and Social Media Multitasking on the Academic Performance of University Students. Computers in Human Behavior. https://doi.org/10.1016/j.chb.2016.11.043

Mahbub, M., Purnamawati, D., Maslamah, Sopakua, S., \& Fauziddin, M. (2020). Educational Data Mining with Clustering Technique on the Distribution of Civil Servant Teachers in Indonesia. Journal of Advanced Research in Dynamical and Control Systems, 12(6), 2097- 2103. https://doi.org/10.5373/JARDCS/V12I6/S20201171

Marc, J. R. (2002). Book Review: E-Learning Strategies for Delivering Knowledge in the Digital Age. Internet and Higher Education, 5, 185-188.

Ministry of Education of the People's Republic of China. (2020) Ministry of Education de- ploys in-depth work on "School 's Out, But Class 's On' elementary and middle schools, 03-06 
Mitchell, T., Aldridge, N., Williamson, W., \& Broomhead, P. (2003). Computer Based Testing of Medical Knowledge. The 7th Computer Assisted Assessment Conference. http://www.intelligentassessment.com/pdf/Intelligent AssessmentTechnologiesCAA2003.pdf

Moorhouse, B. L. (2020). Adaptations to Face-to-Face Initial Teacher Education Course "Aforced" Online due to the COVID-19 Pandemic. Journal Education for Teaching: International Research and Pedagogy. https://doi.org/https://doi.org/10/1080/02607476.2020 .1755205

Naserly, M. K. (2020). Implementasi Zoom, Google Classroom, dan Whatsapp Group dalam Mendukung Pembelajaran Daring (Online) pada Mata Kuliah Bahasa Inggris Lanjut (Studi Kasus Pada 2 Kelas Semester 2, Jurusan Administrasi Bisnis, Fakultas Ekonomi dan Bisnis, Universitas Bina Sa. Aksara Public, 4(2), 155-165.

Obiakor, T., \& Adeniran, A. (2020). COVID-19: Impending Situation Threatens to Deepen Nigeria's Education Crisis. Center for the Study of the Economi of Africa, 1-7.

Oknisih, N., \& Suyoto, S. (2019). Penggunaan Aplen (Aplikasi Online) sebagai Upaya Kemandirian Belajar Siswa. In Seminar Nasional Pendidikan Dasar (Vol. 1, No. 01)

Osuji. (2012). The Use of E-Assessments in the Nigerian Higher Education System. Turkish Online Journal of Distance Education, 13(4), 1-13. https://doi.org/10.17718/tojde.25466

Pramudibyanto, H., Khasanah, D. R., \& Widuroyekti, B. (2020). Pendidikan dalam Masa Pandemik COVID-19. Jurnal Sintesa, 10(1), 41-48.

Purwanto, A., Pramono, R., Asbari, M., Santoso., P. B., Wijayanti, L. M., Hyun, C. C., et al. (2020). Studi Eksploratif Dampak Pandemi COVID-19 Terhadap Proses Pembelajaran Online di Sekolah Dasar. Journal of Education, Psychology, and Counseling, 2, 1-9. 
Raaheim, A., Mathiassen, K., Moen, V., Lona, I., Gynnild, V., Bunæs, B. R., \& Hasle, E. T. (2019). Digital AssessmentHow Does It Challenge Local Practices and National Law? A Norwegian Case Study. European Journal of Higher Education, 9(2), 219-231. https://doi.org/10.1080/21568235.2018.1541420

Sadikin, A., \& Hamidah, A. (2020). Pembelajaran Daring di Tengah Wabah Covid-19. BIODIK: Jurnal Ilmiah Pendidikan Biologi, 6(2), 214-224. https://doi.org/10.17509/t.v6i2.20887

Sahu, P. (2020). Closure of Universities Due to Coronavirus Disease 2019 (COVID-19): Impact on Education and Mental Health of Students and Academic Staff. Cureus, 2019(4), 4-9. https://doi.org/10.7759/cureus.7541

Salcedo A, Cherelus G.: Coronavirus Travel Restrictions, Across the Globe. The New York Times. 2020, Accessed: March 26, 2020: https://www.nytimes.com/article/coronavirustravel- restrictions.html

Sarkar, S. (2012). The Role of Information and Communication Technology (ICT) in Higher Education for the 21st Century. The Science Probe, 1(1), 30-41

Satrianingrum, A. P., \& Prasetyo, I. (2020). Persepsi Guru Dampak Pandemi Covid-19 terhadap Pelaksanaan Pembelajaran Daring di PAUD. Jurnal Obsesi: Jurnal Pendidikan Anak Usia Dini, 5(1), 633. https://doi.org/10.31004/obsesi.v5i1.574

Smedley, J.K. (2010). Modelling the Impact of Knowledge Management using Technology. or Insight (2010) 23, 233250.

Siddiqui, S., \& Singh, T. (2016). Social Media its Impact with Positive and Negative Aspects. International Journal of Computer Applications Technology and Research. https://doi.org/10.7753/ijcatr0502.1006 
Sobron, A. N., \& Bayu, R. (2019). Persepsi Siswa Dalam Studi Pengaruh Daring Learning Terhadap Minat Belajar IPA. SCAFFOLDING: Jurnal Pendidikan Islam dan Multikulturalisme, 1(2), 30-38.

Sulisworo, D., Nasir, R., \& Maryani, I. (2016). Identification of Teachers' Problems in Indonesia on Facing Global Community. International Journal of Research Studies in Education, $6(2)$, 81-90. https://doi.org/10.5861/ijrse.2016.1519

Sun, P. C., Tsai, R. J., Finger, G., Chen, Y. Y., \& Yeh, D. (2008). What Drives A Successful E-Learning? An Empirical Investigation of the Critical Factors Influencing Learner Satisfaction. Computers and

Education. https://doi.org/10.1016Zj.compedu.2006.11.007

Sun, S. Y. H. (2014). Learner Perspectives on Fully Online Language Learning. Distance Education. https://doi.org/10.1080/01587919.2014.891428

Suryawan, O. (2020). Guru Diminta Aktif Awasi Pembelajaran Daring Agar Siswa Tetap Fokus. BBALIPUSPANEWS.COM.

Talebian, S., Mohammadi, H. M., \& Rezvanfar, A. (2014). Information and Communication Technology (ICT) in Higher Education: Advantages, Disadvantages, Conveniences and Limitations of Applying E-learning to Agricultural Students in Iran. Procedia - Social and Behavioral Sciences, 152, 300-305. https://doi.org/10.1016/j.sbspro.2014.09.199

Tim, C. I. (2020). Corona, Kelas Daring, dan Curhat 2 Guru untuk Orang Tua. CNN Indonesia. https:// m.cnnindonesia.com/gayahidup/2020033016505 3-284-488368/coronakelas-daring-dan-curhat-2-guruuntuk-orangtua

Timmis S, Broadfoot P, Sutherland R, Oldfield A: Rethinking Assessment in A Digital Age: Opportunities, Challenges and Risks. $\mathrm{Br}$ Educ Res J. 2016, 42:454-476. 10.1002/berj.3215 
UNESCO (2002), Information and Communication Technology in Education. A Curriculum for Schools and Programme for Teacher Development. Division of Higher Education. (2002). Retrieved 05/22/2014, from http://unesdoc.unesco.org/images/0012/001295/12953 8e.pdf.

Ur T.A. \& Weggen C.C. (2000). Corporate E-Learning: Exploring a New Frontier, San Francisco, CA: WR Hambrecht and Co. Available from:http://www.spectrainteractive.com.

Valentina, A., \& Abaidoo Nelly. (2015). The Role of E-Learning, Advantages and Disadvantages of Its Adoption Inhigher Education. International Journal of Instructional Technology and Distance Learning, 12(1), 29-42. http://itdl.org/Journal/Jan_15/Jan15.pdf\#page=7

Verawardina, U., Asnur, L., Lubis, A. L., Hendriyani, Y., Ramadhani, D., Dewi, I. P., Darni, R., Betri, T. J., Susanti, W., \& Sriwahyuni, T. (2020). Reviewing online learning facing the Covid-19 outbreak. Talent Development and Excellence, 12(SpecialIssue3), 385-392. http://www.iratde.com/index.php/jtde/article/view/2 81

Verawardina, U. (2017). Penggunaan Media Adaptive and Engaging E-Learning Terhadap Keterampilan Mahasiswa dalam Membuat Media E-Learning. Jurnal Pendidikan Informatika dan Sains, 6(1), 114-125.

Wagner, N., Hassanein, K. \& Head, M. (2008). Who Is Responsible for E-Learning in Higher Education? A Stakeholders' Analysis. Educational Technology \& Society, 11 (3), 26-36.

Codone, S. (2001) An e-Learning Primer, Raytheon Interactive. Available from: http:/ / faculty.mercer.edu

Wahyuni, D. (2018). Peningkatan Kompetensi Guru Menuju Era Revolusi Industri 4.0. Info Singkat - Pusat Penelitian Badan Keahlian DPR RI 2018. 
Wang, Y. S., Wang, Y. M., Lin, H. H., \& Tang, T. I. (2003). Determinants of User Acceptance of Internet Banking: An Empirical Study. International Journal of Service Industry Management, 14, 501-519.

Watson, G., \& Sottile, J. (2010). Cheating in the Digital Age: Do Students Cheat More in Online Courses? Online Journal of Distance Learning Administration, 13(1). file:///E:/refference of e learning book/Watson.html

Wicaksono, V. D., \& Rachmadyanti, P. (2016). Pembelajaran Blended Learning Melalui Google Classroom di Sekolah Dasar. Seminar Nasional Pendidikan PGSD UMS \& HDPGSDI Wilayah Timur.

Yang, N. \& Arjomand, L. H. (1999). "Opportunities and Challenges in Computer- Mediated Business Education: An Exploratory Investigation of Online Programs," Academy of Educational Leadership Journal, 3 (2), 17-29

Zeitoun, H. (2008). E-learning: Concept, Issues, Application, Evaluation, Riyadh: Dar Alsolateah publication.

Zhou, L., Wu, S., Zhou, M., \& Li, F. (2020). 'School's Out, But Class' On', The Largest Online Education in the World Today: Taking China's Practical Exploration During The COVID19 Epidemic Prevention and Control As an Example. SSRN Electronic Journal, 4(2), 501-519. https://doi.org/10.2139/ssrn.3555520

URL:

The Educating despite the COVID-19 outbreak: lessons from Singapore . (2020). Accessed: March 20, 2020: https:// www.timeshighereducation.com/blog/educatin g-despite-covid-19- outbreak-lessons-singapore.

Coronavirus: universities are shifting classes online - but it's not as easy as it sounds. (2020). Accessed: March 9, 2020: http:/ / theconversation.com/coronavirus-universitiesare-shifting- classes-online-but-its-not-as-easy-as-itsounds-133030. 
As coronavirus spreads, the decision to move classes online is the first step. What comes next?. (2020). Accessed: March 6, 2020: $\quad$ https://www.chronicle.com/article/AsCoronavirus- Spreads-the/248200.

The COVID-19 crisis and international students . (2020). Accessed: March 19 , 2020: https://www.insidehighered.com/views/2020/03/19/h igher-ed-institutions-arent-supporting- internationalstudents-enough....

Flexible admissions could mitigate COVID-19 impact . (2020). Accessed: March 8, 2020: https://www.timeshighereducation.com/news/flexibleadmissions-could-mitigate-covid-19- impact

Coronavirus COVID-19 - latest update on Kingston University's response . (2020). Accessed: March 27, 2020: https://www.kingston.ac.uk/news/article/2306/27mar-2020-coronavirus- covid19-latest-update-onkingston-universitys-re....

Strategi Belajar Kemendikbud di Masa Pandemi Covid-19" 02 Juni 2020, https://www. republika.co.id. https://www.msn.com/id-id/berita/nasional/strategibelajar-kemendikbud-di-masa-pandemi-covid-19/arBB13v5eS. diakses 3 Oktober 2020.

"Akses Ponsel Terbatas, Nadiem Sebut Guru 'Terpaksa' Kreatif", 24 Maret 2020, https://www. cnnindonesia.com/nasion al/20200324150150-20-486501/ akses-ponsel-terbatasnadiemsebut-guru-terpaksa-kreatif, diakses 31 Maret 2020.

"Belajar di Rumah, Kenapa Tidak?", Media Indonesia, 6 April 2020, hal. 9 . 
"Bila Belajar di Rumah Diperpanjang, Nadiem: Tak Harus Online dan Akademis", 25 Maret 2020, https:www.kompas.com/edu/ $\mathrm{read} / 2020 / 03 / 25 / 154226271 /$ bila-belajar-dirumahdiperpanjang-nadiemtak-harus-onlinedanakademis?page=all, diakses 30 Maret 2020 .

"Kemendikbud Bekerja Sama dengan Operator Telekomunikasi Sukseskan Pembelajaran di Rumah", 26 Maret 2020, https:// www.kemdikbud.go.id/main blog/2020/03/kemendikbudbekerja-sama-denganoperatortelekomunikasi-sukseskanpembelajaran-dirumah, diakses 30 Maret 2020. "Siswa Masih Terbebani", Kompas, 14 April 2020, hal. 5

"Suka Duka Belajar di Rumah", 26 Maret 2020, https:/ / bebas.kompas.

$\mathrm{id} /$ baca/riset/2020/03/26/sukaduka-belajar-di-rumah/, diakses 31 Maret 2020. "Wabah Corona, Nadiem: Tak Semua Pembelajaran Online dari Sekolah akan Optimal", 27 Maret 2020, https://www.kompas.com/edu/ $\mathrm{read} / 2020 / 03 / 27 / 080000471 /$ wabah-corona-nadiem-taksemua-pembelajaran-online-darisekolah-akanoptimal, diakses 30 Maret 2020.

"Warna-Warni Curhatan Guru dan Dosen yang Kini Terpaksa Mengajar Lewat Dunia Maya", 24 Maret 2020, https://www.vice.

com/id_id/article/pke8ak/sukaduka-belajar-jarak-jauhkarenacorona-buat-guru-dan-dosen-diindonesia, diakses 30 Maret 2020. 


\section{TENTANG PENULIS}

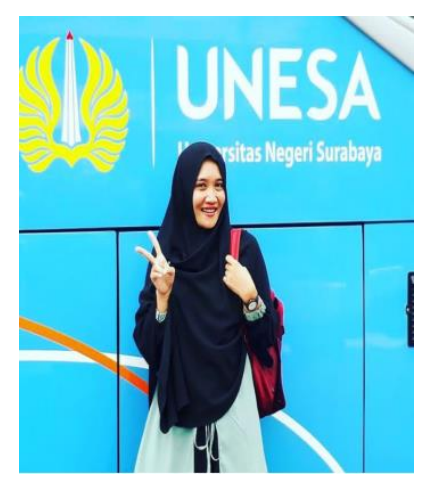

Balqis Husain, M.Pd.B.I, Merupakan anak ketiga dari Pasangan Arsad Husain dan Talha Buhang, lahir pada tanggal 26 September 1984. Penulis menyelesaikan studi strata satu pada tahun 2012 di Universitas Khairun (Unkhair) Ternate, Jurusan Pendidikan Bahasa Inggris. Pada tahun 2013, penulis melanjutkan studi di program studi Pasca Sarjana Pendidikan Bahasa Inggris, Universitas Ahmad Dahlan (UAD) Yogyakarta. Penulis mengawali karir sebagai Dosen di Universitas Pasifik (UNIPAS) Morotai, Fakultas Keguruan dan Ilmu Pendidikan, Program Studi Pendidikan Bahasa Inggris sejak tahun 2015 sampai dengan saat ini. Berbagai pencapaian telah diukir oleh penulis sejak meniti karir sebagai dosen. Penulis pernah menjadi salah satu peserta Dosen Magang di Universitas Negeri Surabaya (UNESA) yang didanai oleh KEMENRISTEKDIKTI pada tahun 2017. Tahun 2018 penulis terpilih sebagai salah satu peserta yang mengikuti Klinik Penulisan Artikel Ilmiah Internasional oleh KEMENRISTEKDIKTI. Pada tahun 2019, penulis menjadi salah satu peserta English Language Training Assistance (ELTA) Program yang diselenggarakan oleh Australia Award Scholarship (AAS) dan IALF Education for Development. Di tahun 2020, penulis terpilih sebagai salah satu peserta Talent Scouting 2020 yang disponsori oleh KEMENDIKBUD. Saat ini penulis aktif dalam menulis karyakarya ilmia. Beberapa karya ilmiah telah di publikasikan di jurnaljurnal Nasional terakreditasi dan telah di publikasikan pada prosiding Internasional. Beberapa karya Ilmiah yang mengulas tentang pembelajaran e-learning di masa pandemi diantaranya; Teachers' Perceptions on Adopting E-Learning during Covid-19 Outbreaks: Advantages, Disadvantages, Suggestions (2020), University Students' Perceptions in Implementing Asynchronous Learning During Covid-19 Era (2020), Parents' Perceptions on 
Implementing E-Learning during New Normal Era at Rural School (2020). Di awal tahun 2021 penulis menyusun buku "Pembelajaran E-learning di Masa Pandemik" sebagai karya penulis, diharapkan buku ini dapat memberikan manfaat bagi pembaca dan menjadi amal jariyah buat penulis. 


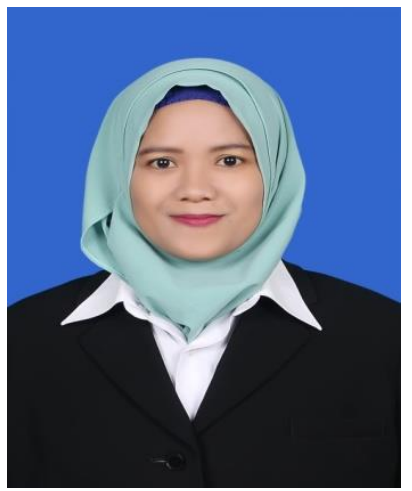

Megawati Basri, M.Pd, lahir di Ambon tanggal 29 Januari 1990 dari pasangan Basri Bugis dan Marwia. Penulis menempuh pendidikan dan memperoleh gelar sarjana S.Pd di Program Studi Pendidikan Bahasa Inggris, Universitas Khairun Ternate Tahun 2012. Tahun 2016 penulis melanjutkan studi di Program Pasca Sarjana Pendidikan Bahasa Inggris, Universitas Ahmad Dahlan Yogyakarta dan menyelesaikannya di tahun 2018. Pada tahun 2018 akhir, penulis menjadi dosen di Program Studi Pendidikan Bahasa Inggris, Fakultas Keguruan dan Ilmu Pendidikan, Universitas Pasifik Morotai. Dan menjabat sebagai Ketua Program Studi Pendidikan Bahasa Inggris (2020Sekarang). Selama menjadi dosen, penulis aktif melakukan kegiatan pengabdian dan penelitian, beberapa penelitian yang dihasilkan yaitu: Faktor Kecemasan Siswa Dalam Berbicara Bahasa Ingris pada Mahasiswa Universitas Ahmad Dalan Yogyakarta (2019), the Use of Video to Improve Students' Pronunciation Competence (2019), Anxiety Level in English Speaking Among Ahmad Dahlan Students (2020), Personality Type Tendency Toward Student's Speaking Anxiety (2020), Teachers' Perception on Adopting E-Learning during Covid-19 Outbreaks: Advantages, Disadvantages, Suggestions, University Students' Perceptions in Implementing Asynchronous Learning During Covid-19 Era (2020). Hingga pada tahun 2021 diterbitkan buku ini sebagai karya pertama penulis. Semoga buku ini memberikan manfaat kepada para pembaca 